\title{
Review \\ The Role of Post-Translational Modifications of Chemokines by CD26 in Cancer
}

\author{
Alexandra De Zutter ${ }^{(0)}$, Jo Van Damme and Sofie Struyf * \\ Laboratory of Molecular Immunology, Department of Microbiology, Immunology and Transplantation, Rega \\ Institute for Medical Research, KU Leuven, B-3000 Leuven, Belgium; alexandra.dezutter@kuleuven.be (A.D.Z.); \\ jo.vandamme@kuleuven.be (J.V.D.) \\ * Correspondence: sofie.struyf@kuleuven.be; Tel.: +32-1632-2422
}

Citation: De Zutter, A.; Van Damme,

J.; Struyf, S. The Role of Post-

Translational Modifications of Chemokines by CD26 in Cancer. Cancers 2021, 13, 4247. https:// doi.org/10.3390/cancers13174247

Academic Editor: Mary

Frances McMullin

Received: 30 June 2021

Accepted: 10 August 2021

Published: 24 August 2021

Publisher's Note: MDPI stays neutral with regard to jurisdictional claims in published maps and institutional affiliations.

Copyright: (c) 2021 by the authors. Licensee MDPI, Basel, Switzerland. This article is an open access article distributed under the terms and conditions of the Creative Commons Attribution (CC BY) license (https:/ / creativecommons.org/licenses/by/ $4.0 /)$.
Simple Summary: Chemokines are central players in cancer and can be post-translationally modified by dipeptidyl peptidase IV (DPPIV)/CD26. This can have different effects on chemokine function, ranging from reduced, unchanged to enhanced activity. CD26 is differentially expressed in tumors, which affects the dominant chemokine isoform present in the tumor microenvironment. In this review, we aim to recapitulate the current knowledge on the interplay between CD26 and chemokine activity in cancer.

Abstract: Chemokines are a large family of small chemotactic cytokines that fulfill a central function in cancer. Both tumor-promoting and -impeding roles have been ascribed to chemokines, which they exert in a direct or indirect manner. An important post-translational modification that regulates chemokine activity is the $\mathrm{NH}_{2}$-terminal truncation by peptidases. CD26 is a dipeptidyl peptidase (DPPIV), which typically clips a $\mathrm{NH}_{2}$-terminal dipeptide from the chemokine. With a certain degree of selectivity in terms of chemokine substrate, CD26 only recognizes chemokines with a penultimate proline or alanine. Chemokines can be protected against CD26 recognition by specific amino acid residues within the chemokine structure, by oligomerization or by binding to cellular glycosaminoglycans (GAGs). Upon truncation, the binding affinity for receptors and GAGs is altered, which influences chemokine function. The consequences of CD26-mediated clipping vary, as unchanged, enhanced, and reduced activities are reported. In tumors, CD26 most likely has the most profound effect on CXCL12 and the interferon (IFN)-inducible CXCR3 ligands, which are converted into receptor antagonists upon truncation. Depending on the tumor type, expression of CD26 is upregulated or downregulated and often results in the preferential generation of the chemokine isoform most favorable for tumor progression. Considering the tight relationship between chemokine sequence and chemokine binding specificity, molecules with the appropriate characteristics can be chemically engineered to provide innovative therapeutic strategies in a cancer setting.

Keywords: CD26; chemokines; truncation; post-translational; modification; tumor

\section{Direct and Indirect Effects of Chemokines in Cancer}

Tumor development and progression are driven by the acquirement of sequential aberrant characteristics within the tumor microenvironment. Malignant and non-malignant cells in the tumor stroma secrete environmental cues to sculpt the tumor micromilieu and support tumor growth, progression, and evasion from the host's immune defense. First identified in tumor supernatants, the role of chemokines herein has been widely acknowledged [1,2]. Chemokines are a large family of small chemotactic cytokines whose main function relies in regulation of the trafficking of leukocytes via G protein-coupled receptors (GPCRs) expressed on target cells. Aside from acting as leukocyte recruiters, chemokine function in cancer has broadened extensively. They can influence cancer progression directly by supporting constitutive growth, survival, invasion, and metastatic spread or indirectly by stimulating or impeding angiogenesis and defining the immune 
response by specific leukocyte subset recruitment to shape primary and metastatic tumor sites. Depending on the chemokine involved, they can either promote or impede tumor progression or even a combination of both depending on the tumor type. Based on the positioning of the conserved $\mathrm{NH}_{2}$-terminal cysteine residues, chemokines are classified into four subclasses, namely $\mathrm{CXC}, \mathrm{CC}, \mathrm{CX}_{3} \mathrm{C}$, and $\mathrm{C}$ chemokines [3].

\subsection{Chemokines}

CXC chemokines are characterized by two $\mathrm{NH}_{2}$-terminal cysteine residues (C) separated by any amino acid $(X)$. Within this subfamily, a distinction is made between $\mathrm{ELR}^{+}$and ELR ${ }^{-}$CXC chemokines, depending on the presence or absence of a glutamic acid (E)-leucine (L)-arginine $(\mathrm{R})$ sequence that precedes the cysteine residues $\mathrm{NH}_{2}$-terminally.

\subsubsection{Tumor-Promoting $\left(\mathrm{ELR}^{+}\right) \mathrm{CXC}$ Chemokines}

ELR $^{+}$CXC chemokine ligands (CXCLs) CXCL1, CXCL2, CXCL3, CXCL5, CXCL6, and CXCL8 all signal through CXC chemokine receptor (CXCR) CXCR1 and/or CXCR2. CXCR1 is a specific receptor for CXCL6 and CXCL8, but CXCR2 is shared by all ELR ${ }^{+}$CXC chemokines. Whereas the angiogenic effects of $\mathrm{ELR}^{+} \mathrm{CXC}$ chemokines are mediated by CXCR2, neutrophils are activated and recruited via CXCR1 and CXCR2 [4,5]. CXCR2 is tightly associated with angiogenic signaling, for instance in gastric cancer, as well as with malignant progression in gastric and triple-negative breast cancer (TNBC) [6-10]. However, the role of CXCR2 and neutrophils in cancer is not fully elucidated yet and most likely not congruent in all tumor types. Boissière-Michot et al. reported that increased expression of CXCR2 coincided with lower risk of relapse and enhanced prognosis in patients with TNBC via recruitment of cytotoxic CD8 ${ }^{+} \mathrm{T}$ cells $[11,12]$. Tumor-derived CXCR1/2 ligands instigated neutrophil-mediated NETosis, which shielded tumor cells from cytotoxicity [13]. Blockage of CXCLs/CXCR2 axis reduced myeloid cell influx in pancreatic ductal adenocarcinoma and improved prognosis [14]. In contrast, knockdown of CXCR2 in the PyMT breast cancer model rendered neutrophils with characteristics in favor of tumor progression [15]. The ELR motif in CXC chemokines seems to be indispensable, but not a sole prerequisite for receptor binding and neutrophil activation [16]. However, a CXCL8 truncated form missing part of the ELR motif, namely CXCL8(10-77), showed reduced potency to induce neutrophil elastase release, but a chemotactic activity comparable to CXCL8 $(1-77)[17,18]$.

\section{CXCL1-2-3}

The chemokines belonging to the growth-related oncogene (GRO) subgroup of CXC chemokines, GRO- $\alpha /$ CXCL1, GRO- $\beta /$ CXCL2, GRO- $\gamma /$ CXCL3, were first identified as growth factors of melanoma cell lines, before being attributed neutrophil chemotactic activity [19]. In addition to melanoma, CXCL1 stimulated pancreatic tumor growth [20,21]. CXCL1-3 chemokines instigate angiogenesis, but CXCL1 showed the strongest angiogenic activity [22]. CXCL1 and CXCL2 were expressed downstream of the transcription factor snail, a mediator of epithelial to mesenchymal transition (EMT) and attracted myeloidderived suppressor cells (MDSCs) to the tumor microenvironment in experimental ovarian cancer [23]. A coordinated interplay between transforming growth factor- $\beta$ (TGF- $\beta$ ) and CXCR2 ligands CXCL1/2/3 also induced neutrophil influx in TNBC [24]. In this breast cancer subtype, cancer stem cells (CSCs) expressed increased amounts of CXCL1, which sustained CSC proliferation and self-renewal. Its expression strongly correlated with pro-angiogenic and tumor-promoting factors [25]. In gastric cancer patients, high CXCL1 expression correlated with invasion and lymph node metastasis [9]. Both in ovarian and gastric cancer patients, CXCL1 expression is associated with poorer prognosis compared to CXCL1-negativity $[9,23]$.

\section{CXCL5}

Epithelial-derived neutrophil-activating peptide-78 (ENA-78)/CXCL5 was first purified from epithelial cells in response to interleukin-1 $\beta$ (IL-1 $\beta$ ) or tumor necrosis factor- $\alpha$ 
(TNF- $\alpha$ ) [26]. Increased levels of CXCL5 were found in patients with non-small cell lung cancer (NSCLC) concurring with enhanced vascularity [27]. In addition, a direct association between CXCL5 expression and tumor growth was found in a mouse model of NSCLC. Administration of CXCL5-neutralizing antibodies attenuated tumor growth, blood vessel outgrowth and metastasis, without affecting tumor cell proliferation. In patients with renal cell carcinoma (RCC), CXCL5 levels were positively correlated with neutrophil numbers and immature MDSC counts [28]. CXCL5 was also reported as a neutrophil attractant in hepatocellular carcinoma (HCC), associated with poor prognosis [29]. However, in a mouse xenograft model wherein metastatic RCC cells were injected in the lungs, elevated levels of CXCL5 and CXCL8 corresponded to an influx of anti-tumoral neutrophils and decrease of metastatic activity [30].

\section{CXCL6}

Granulocyte chemotactic protein-2 (GCP-2)/CXCL6 was originally purified from osteosarcoma cells and identified as a neutrophil attractant [31]. Although it can activate both CXCR1 and CXCR2, its affinity for CXCR1 is lower than for CXCR2 [32]. CXCL6 is a weak proliferative inducer of endothelial cells, but acts as an endothelial chemoattractant and as such positively contributes to angiogenesis, as evidenced in the rat corneal micropocket model [33]. Human microvascular endothelial cells (HMVECs) stimulated with inflammatory mediators produced CXCL6, CXCL8, and CC chemokine ligand 2 (CCL2) and in synergy with the latter, CXCL6 was a potent chemoattractant for neutrophils [34]. Additionally, in gastro-intestinal tumors, endothelial CXCL6 production was evidenced and coincided with leukocyte infiltration and matrix metalloproteinase-9 (MMP-9) expression. Recombinant overexpression of the potent truncated murine CXCL6(9-78) in a mouse model of melanoma concurred with the recruitment and stimulation of tumor-associated neutrophils (TANs). This led to an increase in MMP-9 production and favored tumor growth through associated angiogenesis, without directly affecting the tumor cells [35]. Treatment with an anti-murine CXCL6 antibody reduced tumor volume and associated lymph node metastases [36].

\section{CXCL7}

Neutrophil-activating peptide-2 (NAP-2) is a typical platelet product and is generated by the cleavage of its precursors connective tissue-activating peptide III and betathromboglobulin by cathepsin G [37]. Intratumoral IL-1 $\beta$-induced expression of NAP2/CXCL7 directly affected in vitro and in vivo tumor growth of clear cell renal cell carcinoma (ccRCC) [38]. Administration of a dual CXCR1/2 pharmacological inhibitor attenuated endothelial cell proliferation and ccRCC growth. CXCL7 expression is increased in several solid tumors, such as colorectal, renal and lung cancer and could therefore have biomarker potential in their diagnosis [39-41]. CXCR2 and CXCL7 overexpression in liver metastases of colorectal cancer was associated with a shorter overall and disease-free survival [42]. In gastric cancer, increased CXCL7 expression correlated with lymph node metastasis [9].

\section{CXCL8}

Interleukin-8 (IL-8)/CXCL8 is physiologically produced by endothelial cells, fibroblasts, leukocytes, and various epithelial cells [43-46]. A direct tumor-promoting role has been ascribed to CXCL8 by promoting in vivo melanoma and in vitro pancreatic tumor growth via CXCR2 [21,47]. CXCL8 is also angiogenic as it induced neovascularization in a rabbit corneal pocket model [48]. Furthermore, serial activation of angiogenic molecules is common to maintain the angiogenic profile. For example, it was shown that vascular endothelial growth factor (VEGF) stimulation upregulated CXCL8, which at its turn induced endothelial chemotaxis, proliferation, and phosphorylation of extracellular signalregulated kinase 1/2 (ERK1/2) through CXCR2 [49]. In human gastric carcinoma, CXCL8 levels correlated with tumor vascularization [50]. In concordance with its primary role as a 
neutrophil attractant in inflammation, in a zebrafish model of glioma, CXCL8 was found to recruit neutrophils via CXCR1 to the tumor in the very early stages of development. Inhibition of CXCR1 decreased neutrophil attraction, proliferation, and formation of a tumor mass [51]. High levels of CXCL1 and CXCL8 were thought to be responsible for $\mathrm{CXCR}^{+}$neutrophil influx in colorectal cancer [52]. Serum concentrations of CXCL8 were higher in patients and corresponded to a shorter overall and relapse-free survival. CXCL8 is also upregulated in breast cancer and associated with poor prognosis [53]. Its expression increased CSC self-renewal of which the presence was correlated with development, progression, and recurrence. The CXCL8/CXCR2 axis was also found to associate with metastasis of melanoma. Other studies reported upregulation of CXCL8 during EMT, with one study specifically reporting CXCR1-mediated chemotaxis of colon carcinoma cells $[54,55]$.

\section{CXCL12}

Although stromal cell-derived factor-1 (SDF-1)/CXCL12 is an ELR ${ }^{-}$CXC chemokine, it possesses angiogenic and pro-tumoral characteristics. CXCR4 has been proposed as the main chemokine receptor on the endothelium and its ligands CXCL12- $\alpha$ and CXCL12- $\beta$ as the major endothelial chemoattractants, amongst the CXC chemokines [56]. CXCL12 is, apart from leukocytes, rather ubiquitously expressed. Its receptor CXCR4 is overexpressed in many tumor types and the associated consequences vary widely [57]. As such, the notion that CXCL12 could be post-translationally modified by, e.g., proteases affecting its activity, has an important impact on tumor biology (vide infra). CXCR4 expression in human glioblastoma tumors and cell lines was linked to CXCL12- $\alpha$-induced proliferation via ERK1/2 and protein kinase B (Akt) signaling [58]. In invasive breast carcinomas, CXCL12secreting carcinoma-associated fibroblasts (CAFs) directly influenced tumor growth [59]. CXCL12 expression was also increased in ovarian cancer cells compared to normal ovarian epithelial cells, which was thought to stimulate proliferation, migration, and invasion of the tumor cells [60]. As evidenced by gene knock-out mice, the CXCL12/CXCR4 axis plays a non-redundant role in vasculogenesis [61]. CXCL12- $\alpha$ can act in series with other angiogenic molecules as it was shown that VEGF and basic fibroblast growth factor (bFGF) stimulation of endothelial cells induced expression of CXCR4. Furthermore, injection of CXCL12- $\alpha$ induced angiogenesis in vivo [62]. Neutralization of CXCR4 with anti-CXCR4 antibodies reduced in vivo tumor growth and vascularization of CXCR4-overexpressing prostate tumors [63]. Apart from tumor growth and angiogenesis, the CXCL12/CXCR4 axis is widely known for its role in predisposing the metastatic niche. Breast carcinoma and melanoma metastases both have a high incidence of CXCR4 expression [64]. In breast cancer cells, CXCR4 signaling induced cell migration and invasion. Suppression of the CXCL12/CXCR4 axis inhibited metastasis to the regional lymph nodes and lungs. CXCL12 signaling through CXCR4 also increased prostate cancer cell adhesion to the endothelium, possibly through the upregulation of $\alpha_{\mathrm{v}} \beta_{3}$ integrins and CD164, and contributed to metastatic spread to the bone $[65,66]$. CXCL12/CXCR4 signaling can also enhance tumor progression by attracting pro-tumoral immunosuppressive immune cells. In ovarian cancer, CXCL12/CXCR4 signaling stimulated tumor angiogenesis, development of cancerinitiating cells and metastasis to the peritoneum via recruitment of immunosuppressive cells, such as regulatory T (Treg) cells [67]. In high grade serous ovarian carcinoma, invariably associated with poor prognosis, a specific accumulation of CXCL12- $\beta$ in a subset of CAFs was essential for the recruitment of intratumoral immunotolerant Tregs [68]. In a murine model of pancreatic cancer, CAFs expressing CXCL12 attracted CXCR4-bearing immunosuppressive cells that rendered the tumor unresponsive to the commonly used $\mathrm{T}$ cell checkpoint inhibitors anti-programmed cell death-ligand 1 (PD-L1) and anti-cytotoxic T lymphocyte-associated antigen-4 (CTLA-4). Administration of AMD3100, a CXCR4 receptor inhibitor, induced $\mathrm{T}$ cell accumulation and cooperated with anti-PD-L1 to reduce tumor burden [69]. 


\subsubsection{Tumor-Obstructing $\left(\mathrm{ELR}^{-}\right) \mathrm{CXC}$ Chemokines}

CXC chemokines lacking the ELR motif and binding to CXCR3 are lymphocyte attractants and exert angiostatic activity.

\section{CXCL4 and CXCL4L1}

Platelet factor-4 (PF-4)/CXCL4 is the oldest member of the chemokine family, its sequence having been published already in 1977. It is secreted from the $\alpha$-granules of platelets and was discovered by Maione et al. to have potent angiostatic activity [70]. This heparin-binding chemokine inhibited endothelial proliferation and migration in vitro and angiogenesis in vivo [71]. Tumor growth was inhibited by CXCL4 via inhibition of angiogenesis in several animal models of cancer, including models of glioma, melanoma, and colon carcinoma [71,72]. Furthermore, CXCL4 complexed with bFGF, which interfered with endogenous and heparin-induced bFGF dimerization, FGF receptor binding and activation [73]. Additionally, direct association between CXCL4 and VEGF165 was reported and CXCL4 inhibited VEGF165- and VEGF121-induced proliferation [74]. However, CXCL4 expression in MC38 colon cancer in mice was shown to coincide with the suppression of a CD8 ${ }^{+} \mathrm{T}$ cell influx and promotion of Treg responses via CXCR3, and accelerated tumor growth [75]. A natural non-allelic variant, platelet factor-4 variant (PF-4var)/CXCL4L1, only differing in three COOH-terminal amino acids, namely Pro58Leu, Lys66Glu, and Leu67His, is characterized by a lower affinity for heparin and chondroitin sulfate and a more outspoken angiostatic activity in vitro and in vivo compared to CXCL4 [76-78]. CXCL4L1 was isolated from thrombin-stimulated platelets, but can also be produced by osteosarcoma cells [79]. CXCL4L1 inhibited growth and metastasis in several cancer models including B16 melanoma, A549 adenocarcinoma, and Lewis lung carcinoma (LLC) via the inhibition of angiogenesis [80]. It was more potent than CXCL10 in the adenocarcinoma model, but showed equal potency compared to CXCL9 in the LLC model. Both CXCL4 and CXCL4L1 attracted activated T cells, natural killer (NK) cells and immature dendritic cells (DCs) via CXCR3A [78,81]. The chemokine receptor CXCR3 exists in two isoforms, CXCR3A and CXCR3B, differing in the $\mathrm{NH}_{2}$-terminal region. Whereas CXCR3A is mediating leukocyte chemoattractant activity, CXCR3B-mediated signaling seems responsible for the angiostatic activity of the ELR ${ }^{-}$CXC chemokines, including CXCL4 and CXCL4L1 [81,82].

\section{CXCL9, CXCL10, and CXCL11}

Interferon- $\gamma$ (IFN- $\gamma$ ) is the major inducer of three CXCR3 ligands, monokine induced by IFN- $\gamma$ (MIG)/CXCL9, $10 \mathrm{kDa}$ IFN- $\gamma$-induced protein (IP-10)/CXCL10 and IFNinducible T cell $\alpha$ chemoattractant (I-TAC)/CXCL11 in mainly endothelial cells, monocytes, fibroblasts, and cancer cells. CXCL10 is induced by both type I $(\alpha / \beta)$ and type II $(\gamma)$ IFN. All three CXCR3 ligands are inhibitors of angiogenesis [83]. CXCL10 attenuated CXCL8- and bFGF-induced neovascularization in the rat cornea micropocket and Matrigel plug assay [83,84]. Mice with A549 adenocarcinoma or NSCLC treated intratumorally with CXCL10 showed a reduction in tumor size, angiogenesis, and metastasis $[80,85]$. CXCL9 also reduced tumor size and attenuated angiogenesis in the LLC model. CXCL9, CXCL10, and CXCL11 recruit CXCR3 ${ }^{+}$immunoreactive leukocytes to boost the host's antitumoral response, such as cytotoxic $\mathrm{CD}^{+}$and $\mathrm{CD}^{+} \mathrm{T}$ helper 1 (Th1), DCs, NK, and NKT cells [86]. CXCL10 also promotes T cell adhesion to the endothelium. In patient-derived RCC samples, increased expression of CXCR3 and CC chemokine receptor 5 (CCR5) on tumor-infiltrating $\mathrm{T}$ lymphocytes was found. The expression of Th1-associated genes, such as CXCL9/10/11, corresponded with increased infiltration of Th1 lymphocytes and favorable prognosis [87]. CXCL9 and CXCL10 expression was associated with CD8 ${ }^{+} \mathrm{T}$ cellinfiltrated melanoma metastases [88]. CXCR3 positivity of CD8 ${ }^{+} \mathrm{T}$ cells corresponded with enhanced survival [89]. In patients with less recurrence of colorectal tumors, a higher infiltration of memory T cells was observed, which was mediated by CXCL9 and CXCL10 [90]. On the contrary, enhanced metastasis of $\mathrm{CXCR}^{+}$tumor cells to metastatic sites expressing 
high concentrations of CXCR3 ligands (e.g., brain, lungs, lymph nodes) has been reported as well for melanoma, breast, and colon cancer [91-94]. As such, CXCL9/10/11 ligands can create a more angiostatic, immunosuppressive environment, but on the other hand they can also contribute to tumor aggressiveness [86]. Given the pivotal function of the CXCR3 ligands in the anti-tumor response, the effects of the processing of these chemokines by CD26 is of great interest (vide infra).

\section{CXCL13 and CXCL16}

B cell-attracting chemokine-1 (BCA-1)/CXCL13 attracts B lymphocytes via Burkitt lymphoma receptor-1 (BLR-1)/CXCR5 and was therefore prompted a function in development of B cell areas in secondary lymphoid tissues [95]. In breast cancer, expression of CXCL13 by follicular T helper (Tfh) cells is linked to the adaptive anti-tumor humoral immune response [96]. Also in colorectal cancer, CXCL13 expression mediates the infiltration of $\mathrm{B}$, Tfh, Th1, and memory $\mathrm{T}$ cells, whereas the loss of CXCL13 expression due to chromosomal instability is associated with relapse [97]. Another CXC chemokine family member, small-inducible cytokine B16/CXCL16 has recently emerged in the regulation of the anti-tumor response. For example, in liver cancer, sinusoidal endothelial cells were reported as primary producers of CXCL16 that recruited CXCR6 ${ }^{+}$anti-tumor NKT cells [98]. CXCL16 is also angiogenic, but its role in cancer remains controversial, as both pro- and anti-tumoral activities are reported [99].

\subsection{Chemokines}

$\mathrm{CC}$ chemokines are characterized by two adjacent $\mathrm{NH}_{2}$-terminal cysteine residues and represent the largest subgroup of chemokines. They seem to be biased towards monocytes, macrophages, lymphocytes, basophils, and eosinophils.

\subsubsection{CCL2}

Monocyte chemotactic protein-1 (MCP-1)/CCL2, initially purified from monocytes and osteosarcoma cells, has both direct and indirect actions in cancer [100]. The chemokine has been shown to directly affect prostate cancer cell proliferation, survival, chemotaxis, invasion, and metastasis $[101,102]$. CCL2 induced chemotaxis of CCR2 ${ }^{+}$endothelial cells in vitro and neovessel formation in vivo in chorioallantoic membrane (CAM) and Matrigel experiments [103]. The angiogenic effect was accompanied by an infiltration of inflammatory cells, but did not depend on it. Nonetheless, the CCL2/CCR2 axis is the main determinant of pro-tumoral MDSC, monocyte and macrophage recruitment in tumors [104-106]. In several cancers, such as ovarian, breast, glioblastoma, squamous cell carcinoma (SCC), and NSCLC, CCL2 expression positively correlated with increased infiltration of tumorassociated macrophages (TAMs) [105]. CCL2 production also recruited TAMs and Tregs to the pre-metastatic niche. Treating immunodeficient mice bearing human breast carcinoma with a CCL2-neutralizing antibody increased survival and inhibited lung micrometastases. Bone marrow endothelial cells were shown to secrete considerably higher levels of CCL2 compared to aortic and dermal endothelial cells, leading to preferential recruitment of prostate cancer cells to the bone and local support of their proliferation [107]. Contrarily, CCL2 also activates neutrophils, arriving in the lung pre-metastatic niche through granulocyte-colony-stimulating factor (G-CSF) activity, to produce reactive oxygen species and thereby limiting lung metastasis of the primary breast tumor [108]. Similarly, in a colon and prostate cancer model, CCL2 recruited cytotoxic T cells to the tumor microenvironment, which was prevented through natural nitration of intratumoral CCL2 [109].

\subsubsection{CCL17 and CCL22}

Thymus and activation-regulated chemokine (TARC)/CCL17 and macrophage-derived chemokine (MDC)/CCL22 are CCR4 ligands. CCR4 is mainly expressed on Th2 and Treg cells, but also in several $\mathrm{T}$ cell malignancies [110-112]. Treatment with mogalizumab (KW-0761), a defucosylated humanized anti-CCR4 antibody, showed promising efficacy 
and safety in patients with relapsed peripheral T cell lymphoma (PTCL), cutaneous T cell lymphoma (CTCL), and relapsed adult T cell leukemia or lymphoma (ATL) $[113,114]$. CCL17 and CCL22 both contribute to an immunotolerant tumoral environment by primarily attracting CCR4 ${ }^{+}$Tregs [115]. Treg infiltration is most often associated with aggressive cancer phenotypes and can function as a gateway towards metastasis [116-119]. High intratumoral concentrations of CCL22 have been reported [120,121]; the source of CCL22 within the tumor stroma is, however, an area of debate, with both tumor and DCs being reported. In ovarian cancer, tumor cell- and TAM-derived CCL22 contributed to tumor growth via stimulation of Treg tumor infiltration, which was associated with reduced survival through suppression of tumor-specific T cell immunity [122]. Elevated expression of CCL17 and CCL22 and consequent infiltration of CCR4 $4^{+}$Tregs has also been reported in Hodgkin lymphomas and gastric cancer [123,124]. Treg depletion enhanced vaccinemediated anti-tumor immunity in patients with metastatic RCC and dual CTLA-4 blockade and CD25 $5^{+}$Treg depletion maximized tumor rejection $[125,126]$. In addition to Tregs, CCL22 production also recruits TAMs to the pre-metastatic niche. The prognostic value of CCL17 and CCL22 expression also depends on the tumor type. In breast cancer patients, increased CCL17 expression was associated with poorer survival, while in melanoma patients increased CCL17 levels corresponded to improved survival $[127,128]$. In human lung cancer and breast cancer, higher CCL22 expression correlated with longer disease-free survival, whereas in SCC this related to poor prognosis $[127,129,130]$.

\subsubsection{CCL4 and CCL5}

Macrophage inflammatory protein-1 $\beta$ (MIP-1 $\beta$ )/CCL4 fulfills pro- and anti-tumoral roles in tumorigenesis. Via stimulation of VEGF-A, CCL4 promoted endometrial carcinoma progression and via upregulation of VEGF-C it contributed to lymphangiogenesis, which correlated with metastasis of oral squamous cell carcinoma (OSCC) [131,132]. CCL4 production by B cells and antigen presenting cells (APCs) or MDSCs has also been associated with Treg recruitment $[133,134]$. In melanoma, B cells expressing CCL4, CCL3, and CCL5 attracted T cells to sustain a pro-inflammatory environment [135]. CCL4 and CCL5 also mediated $\mathrm{CD}^{+}$and $\gamma \delta \mathrm{T}$ cell responses, which enhanced anti-tumor immunity $[136,137]$. Regulated on activation, normal $\mathrm{T}$ cell expressed and secreted (RANTES)/CCL5 is a chemoattractant for lymphocytes, monocytes, DCs, eosinophils, basophils, NK, and Treg cells. In pancreatic adenocarcinoma, tumor cells were shown to express increased levels of CCR5 ligands, which recruit CCR5 ${ }^{+}$Treg cells to the tumor and promote immune tolerance and progression [138]. In breast cancer, CCL5-producing Treg cells promoted metastatic progression via CCR5-expressing breast cancer cells [139]. In addition, the CCL5/CCR5 axis also correlated with a more aggressive phenotype [140]. For example, CCL5 was associated with breast cancer grade and metastasis. The chemokine was considered to contribute to breast cancer progression through infiltration of macrophages and MMP-2 and MMP-9 production by both cancer cells and infiltrating monocytes [141]. Also in melanoma, increasing concentrations of CCR5 ligands were found in the tumor, such as CCL3/4/5, which could also lead to the infiltration of CCR $5^{+}$MDSCs [142].

\subsubsection{CCL19, CCL20, and CCL21}

Liver and activation-regulated chemokine (LARC)/CCL20 is the only known chemokine ligand for CCR6 [143]. Recently, a pro-angiogenic role for CCL20 in hepatitis C virus (HCV)specific angiogenesis has been described [144]. CCR6 is mainly expressed on immune cells such as immature DCs, NK cells, Th17, Treg, and B cells [145]. Therefore, the main function of CCL20 relies on the recruitment of pro-tumoral Treg and Th17 lymphocytes to the tumor microenvironment [146-148]. However, in breast carcinoma patients, a higher expression of CCL20 was associated with an increased infiltration of immature CCR6 ${ }^{+}$DCs that activate $\mathrm{CD}^{+} \mathrm{T}$ cells [149]. Similar findings, i.e., reduced tumor growth, were reported in different murine cancer models [150]. Together with CXCR4, CCR7 is one of the main regulators of metastasis. Macrophage inflammatory protein-3 $\beta$ (MIP-3 $\beta$ )/CCL19 and secondary 
lymphoid-tissue chemokine (SLC)/CCL21 are specific CCR7 ligands. Whereas different organs can attract CXCR4-expressing tumor cells, CCR7 expression is mainly a prerequisite for dissemination to secondary lymphoid organs. As such, increased CCR7 expression in certain tumor types has been associated with invasiveness and poor survival. Signaling by CCL21 through CCR7 is the principal driver for secondary lymph node metastasis of several cancers, such as breast, gastric, colorectal cancer, and murine B16 melanoma [151]. For example, increased expression of CCL19 and CCL21 by lymphatic endothelium in squamous cell carcinoma of the head and neck (SCCHN) promoted dissemination of CCR7 ${ }^{+}$ tumor cells to secondary lymphoid tissues [152].

\subsubsection{CCL18 and CCL28}

Pulmonary and activation-regulated chemokine (PARC)/CCL18 exerts rather protumoral functions in tumor progression. The receptor(s) for CCL18 are not yet unequivocally identified, but both CCR8 and PITPNM3 have been suggested to be activated by this chemokine. TAMs are the main producers of CCL18, which was shown to promote breast cancer cell invasiveness and metastasis through stimulation of integrin clustering and by promoting adhesiveness to the extracellular matrix [153]. CCL18 expression in blood or tumor stroma was also associated with metastasis and reduced survival. In addition, CCL18-producing TAMs also promoted in vitro human umbilical vein endothelial cell (HUVEC) migration and tube formation, tumor angiogenesis, and EMT of breast cancer cells via its receptor PITPNM3 [154]. Mucosa-associated epithelial chemokine (MEC)/CCL28 is a specific CCR10 ligand, whose main action also relies on the induction of angiogenesis and the infiltration of Tregs. In ovarian cancer, CCL28 expression correlated with a poor prognosis [155]. CCL28 was mainly produced by tumor cells and promoted the recruitment of CCR $10^{+}$Treg cells, which supported immune tolerance by suppression of cytotoxic CD8 ${ }^{+}$ $\mathrm{T}$ cells. Tumor hypoxia switches on CCL28 expression and promotes immune tolerance and angiogenesis to support tumor growth $[155,156]$.

\subsubsection{CCL3L1}

CCL3L1/MIP-1 $\alpha / \mathrm{LD} 78 \beta$ is a highly related non-allelic variant of CCL3/MIP-1 $\alpha / \mathrm{LD} 78 \alpha$ [157]. Although CCL3L1 only differs in three amino acids from CCL3, CCL3L1 has enhanced CCR5 and atypical chemokine receptor 2 (ACKR2)/D6 receptor binding affinities $[158,159]$. CCL3L1 is also the most potent natural CCR5 binder and therefore also displays remarkably higher anti-HIV activity than other CCL3 isoforms and equal if not higher HIV-suppressive activity compared to CCL5. This enhancement was reportedly due to a proline at position 2. CCL3L1 was also a more efficient human lymphocyte and monocyte attractant than CCL3 [159]. Consequently, CCL3L1 forms an intriguing substrate for CD26 (vide infra). High levels of the LD78 gene transcripts were found in acute non-lymphocytic as well as lymphocytic leukemic cells, which raises the idea that LD78 could be involved in the neoplastic transformation of hematopoietic cells [160].

\section{3. $\mathrm{CX}_{3} \mathrm{C}$ Chemokines}

Within the $\mathrm{CX}_{3} \mathrm{C}$ chemokines, three amino acids separate the two conserved $\mathrm{NH}_{2}-$ terminal cysteine residues. Remarkably, fractalkine/neurotactin/CX ${ }_{3} \mathrm{CL1}$ is a transmembrane chemokine comprising a chemokine domain atop a mucin stalk that, given its unique structure, is highly capable to interact with $\mathrm{CX}_{3} \mathrm{CR} 1$-bearing leukocytes. As such, $\mathrm{CX}_{3} \mathrm{CL1}$ is able to efficiently capture circulating leukocytes alone or in conjunction with other adhesion molecules and then by interacting with its $C X_{3} C R 1$ receptor tether them firmly to the endothelium [161]. This process has been reported for resting monocytes, resting and activated $\mathrm{CD}^{+} \mathrm{T}$ lymphocytes, and resting and activated NK cells. Soluble CX ${ }_{3} \mathrm{CL} 1$ can be released from the surface (due to a dibasic cleavage region probably similar to syndecans) and was shown to be chemotactic for monocytes, T cells, and NK cells [162]. NK cell-mediated trafficking towards tumor cell-infiltrated lungs in mice was shown to be dependent on the $\mathrm{CX}_{3} \mathrm{CL1} / \mathrm{CX}_{3} \mathrm{CR} 1$ axis [163]. A study in mice showed that local tumoral 
production of $\mathrm{CX}_{3} \mathrm{CL1}$ promoted the anti-tumor response by recruitment of NK cells [164]. NK cells have been shown to express a number of chemokine receptors in resting and activated state such as CXCR1, CXCR4, and CX ${ }_{3}$ CR1 [165]. In activated state, expression of CCR1/2/4/8 may also be upregulated [166]. Lastly, a role for the $\mathrm{CX}_{3} \mathrm{CL1} / \mathrm{CX}_{3} \mathrm{CR} 1$ axis in the bone tropism of prostate cancer cells was described [167].

\section{The Interplay between Dipeptidyl Peptidase IV/CD26 and Chemokines in Cancer}

Enzymatic cleavage is an important post-translational modification that regulates chemokine function. This cleavage can be mediated by different proteases, such as MMPs, plasmin, thrombin, aminopeptidase N (CD13), and dipeptidyl peptidases. This review will focus on a specific type of dipeptidyl peptidase, whereas the impact of other proteases on chemokines are described in more detail in $[168,169]$.

\subsection{CD26 Biology}

Dipeptidyl peptidase IV (DPPIV)/CD26 is type II membrane glycoprotein of approximately $110 \mathrm{kDa}$. It consists of a short intracellular domain of 6 amino acids, a transmembrane region, and a large extracellular domain spanning from amino acid 7 to 28 and 29 to 766 , respectively. The extracellular domain comprises intrinsic dipeptidyl peptidase activity to cover its enzymatic action. CD26 has three functions: adenosine deaminase (ADA) binding, extracellular matrix binding, and peptidase activity. More specifically, CD26 is a serine-type prolyl oligopeptidase that specifically clips dipeptides at the $\mathrm{NH}_{2}$-terminus of the peptide chain if the penultimate amino acid is a proline or alanine [170]. This reflects the unique properties of $\mathrm{CD} 26$, as the peptide bond before or after a proline, structurally a unique amino acid, is in general quite resistant to protease cleavage [171]. CD26 exists in two forms: membrane-bound and soluble (after cleavage by metalloproteinases). The presence of the membrane-bound form of CD26 has been described on epithelia, melanocytes, $\mathrm{T}$ cells, activated NK, and B cells. On human T cells, CD26 expression is preferentially restricted to $\mathrm{CD}^{+} \mathrm{T}$ cells and its upregulation, together with CXCR3, can be linked to cell activation and acquirement of immunological memory. This is in line with the observation that the cytoplasmic domain of CD26 interacts with CD45 in T cells [172]. As such, CD26 aids in CD45 colocalization with T cell receptor signaling molecules, thereby enhancing tyrosine phosphorylation of several signaling molecules and IL-2 production. In addition, CD26 activity can regulate the immunological response by adjusting the target cell specificity and migratory cell subset. As a soluble form, CD26 (sCD26) exists in serum, plasma and seminal fluid. The soluble form in the serum starts at amino acid 39 and lacks the cytoplasmic and transmembrane region [173]. The COOH-terminal loop is vital for its catalytic activity and dimerization, as only CD26 homodimers are considered enzymatically active. When comparing different species, the CD26 protein displays high sequence conservation [174]. The translation of observations in different species will therefore depend on the sequence similarity of CD26 substrates across different species. CD26 has a range of biologically important substrates including neuropeptides (substance $\mathrm{P}$, neuropeptide Y), vasoactive intestinal peptide, glucagon-like peptides (glucagon, GLP-1/2, GIP), cytokines (CSFs), and chemokines. For a more thorough overview of CD26 substrates we refer to [170,175-177]. Some chemokines are as susceptible to CD26 cleavage as the incretins. This is most likely due to their flexible $\mathrm{NH}_{2}$-terminus that can easily fit within the enzymatic pocket of CD26. Cleavage by CD26 can have differential effects, ranging from enhancing or reducing protein activity or leaving the activity unchanged.

\subsection{CD26 in Cancer}

While CD26 expression in normal tissues is rather ubiquitous, in neoplasms, CD26 is aberrantly expressed, such that CD26 was even considered as a biomarker. Depending on the tumor type, expression patterns vary from down- to upregulation, attributing both tumor-promoting and -suppressive roles to CD26 (Figure 1). The absence or presence of CD26 expression in cancer can often be correlated with prognosis and is described in more 
detail in [178]. Enhanced levels of CD26 were detected in multiple cancers such as thyroid and ovarian cancer, SCC, malignant mesothelioma, metastatic colon carcinoma, lung and esophageal adenocarcinoma, and several types of T cell malignancies [179-185]. Overexpression of CD26 also correlated with metastasis in esophageal and colorectal cancer and resistance to chemotherapy $[182,186,187]$. In such cases, treatment with a CD26 inhibitor, such as sitagliptin, an oral hypoglycemic drug primarily used in diabetes patients, could attenuate cancer progression and improve survival. For example, CD26 inhibition mitigated malignant properties of thyroid carcinoma cells in vitro and xenograft tumor growth in vivo [188]. In a xenograft mouse model of mesothelioma, treatment with a humanized anti-CD26 monoclonal antibody reduced tumor growth and enhanced survival [184]. The combined use of CD26 inhibitors and metformin improved overall survival in diabetic patients with colorectal or lung cancer [189]. On the other hand, loss or alteration of membrane CD26 expression has been described in melanoma, NSCLC, prostate and endometrial adenocarcinoma, and ovarian and breast carcinoma [185,190-197]. In several of these tumors, CD26 was designated as a tumor suppressor, as re-expression of the enzyme in malignant cells would inhibit tumor cell proliferation, migration, invasion, and tumorigenicity in mice [190-192,195]. This has been elegantly shown in melanoma, where loss of CD26 expression on melanocytes coincided with progression to a malignant phenotype [198]. This progression was characterized by a rise in growth factor independence and chromosomal abnormalities. Reintroduction of CD26 expression resulted in a loss of tumorigenicity, loss of anchorage-independent growth and dependence on exogenous growth factors for survival. The protease activity of CD26 was apparently responsible for the suppression of tumorigenicity, but not for regulating the dependence on exogenous growth factors.

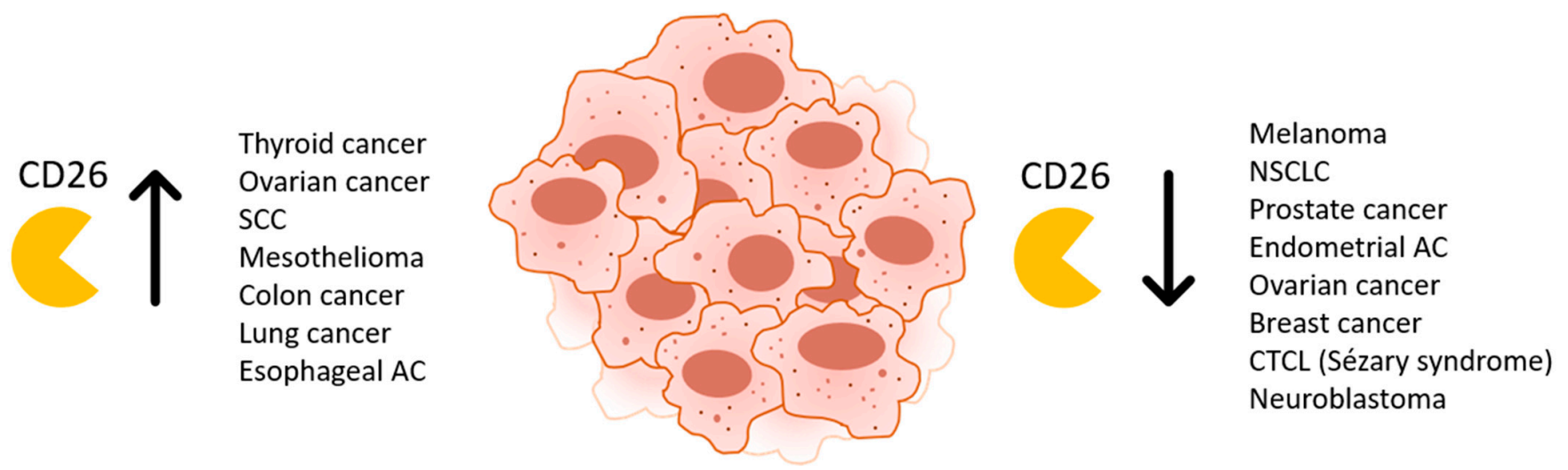

Figure 1. Differential expression (up- or downregulation) of CD26 in tumors. CD26 is rather ubiquitously expressed in normal tissue. On some malignant cells CD26 expression is absent or suppressed (right side), which might coincide with tumor progression, e.g., in melanoma. On the contrary, enhanced CD26 levels have also been detected (left side) and correlated with metastasis and resistance to chemotherapy in e.g., esophageal AC and colon cancer. Adenocarcinoma (AC); Cutaneous T cell lymphoma (CTCL); Non-small cell lung cancer (NSCLC); Squamous cell carcinoma (SCC).

\subsection{Evidence for Post-Translational Modification of Chemokines in Tumors}

Many chemokines were originally identified through purification from conditioned medium, derived from tumor cells or leukocytes, based on chemotactic activity. Often the abundance of truncated chemokines was higher in the conditioned medium from leukocytes, as those are major producers of chemokine-processing enzymes. For instance, in a study comparing purified chemokine isoforms from peripheral blood mononuclear cells and tumor cells, $\mathrm{NH}_{2}$-terminally truncated forms of CXCL5 [CXCL5(8,9-78)], CXCL1 [CXCL1 $(4,5,6-78)]$, and CXCL3 [CXCL3(5-73)] were predominantly purified from leukocytes, whereas tumor cells mainly produced the intact chemokine isoforms [199]. The truncated chemokine isoforms showed increased potency to activate neutrophils. This implicates that in a leukocyte-rich tumor stroma $\mathrm{ELR}^{+} \mathrm{CXC}$ chemokines are further po- 
tentiated to attract neutrophils, which often exert rather pro-tumoral activities. On the contrary, leukocyte-derived proteases turn the monocyte-attracting chemokines from the MCP subfamily into antagonists. Natural $\mathrm{NH}_{2}$-terminally truncated CCL2, CCL2(5-76), and MCP-2/CCL8, CCL8(6-76), were purified from mononuclear cells, and though lacking monocyte chemotactic activity, CCL8(6-76) was able to completely block the chemotactic effect of CCL2, CCL5, MCP-3/CCL7, and CCL8 [200,201]. The conversion of CCL8 into an antagonist by specific proteases in the tumor stroma hampered the therapeutic effect that was envisaged by treatment of tumors with CCL8-expressing oncolytic parvoviruses [202]. In the following paragraphs, we summarize the knowledge on the effect of chemokine processing by CD26 in cancer.

\subsection{Effect of CD26-Mediated Cleavage on Chemokine Activity in Cancer Biology and Evidence in Tumors}

\subsubsection{Processing by CD26 Leaves Chemokine Activity Unaffected}

Human CCL3 is encoded by two highly related non-allelic genes: CCL3 (LD78 $\alpha$ ) and CCL3L1 (LD78 $\beta)$, which differ only in three amino acids. Compared to CCL3L1, human CCL3 is not a CD26 substrate, because the proline at position 2 is interchanged for a serine. Although a penultimate $\mathrm{NH}_{2}$-terminal proline residue is present, the MCPS CCL2, CCL7, and CCL8 remain intact upon incubation with CD26 and are protected by the cyclic $\mathrm{NH}_{2}$-terminal pyroglutamic acid [203]. A link between CCL2 and CD26 has been reported in high-fat diet-induced liver carcinogenesis [204]. It was argued that increased CD26 activity in this HCC model promoted angiogenesis and dissemination via upregulation of CCL2 in serum. Although the mechanisms were poorly understood, increased CCL2 and CD26 levels were also observed in HCC patients, of which the latter correlated with poor prognosis [204]. Murine CXCL1 (KC) and human CXCL2 (GRO- $\beta$ ) both have a proline at position 2 and an alanine at position 4. Although $\mathrm{CD} 26$ removes two $\mathrm{NH}_{2}$-terminal amino acids from GRO- $\beta$, it is not known whether KC is also a substrate of CD26 [205]. Although, a 2 amino acid truncated form of KC was found in the supernatant of stromal cells that were stimulated with the hematoregulatory peptide SK\&F 107647. This truncated isoform lacked synergistic growth activity for the colony forming unit for granulocytes and macrophages (CFU-GM), the earliest recognized precursor of osteoclasts [206]. Additionally, isoforms of KC and GRO- $\beta$ missing up to 4 amino acids were purified from SK\&F 107647-stimulated cell lines that were more potent compared to their parental counterparts [207]. It was not clear whether the production of these isoforms was mediated by CD26. However, this could be plausible considering the presence of a penultimate alanine in the 2 amino acid truncated chemokines. CXCL6 is converted by CD26 into CXCL6(3-77) through cleavage after its penultimate proline residue. However, the intact and truncated isoform showed equal activity on neutrophils [203]. The detection of truncated CXCL6 isoforms is not yet reported in tumors, but downregulation of CD26 and increased levels of CXCL6 coincided in endometriosis, which is often accompanied by abnormal angiogenesis [208].

2.4.2. Depending on the Receptor Involved, Processing by CD26 Renders CCL3 and CCL4 with Pro- or Anti-Tumoral Activity

When human peripheral blood lymphocytes were stimulated by cytokines IL-2 and IL-12, $\mathrm{NH}_{2}$-terminally truncated forms of CCL4, such as CCL4(3-69), were produced [209]. CCL4 is a ligand for CCR5, chemotactic for T cells and macrophages, and can inhibit HIV interactions with the CCR5 co-receptor. The two amino acid truncated form retained its ability to downmodulate cell surface expression of CCR5 and inhibited CCR5-mediated HIV entry [210]. CCL4(3-69) retained its CCR5 signaling capacities, but gained CCR1 and CCR2b calcium signaling, which is thought to install MDSC, immature DC, monocyte, and lymphocyte chemotactic properties [168]. Murine CCL3 and CCL4 also enhance CSFstimulated hematopoietic progenitor cell (HPC) colony formation in vitro and proliferation in vivo. CD26-mediated truncation of these two murine MIPs resulted in chemokine products that lost their enhancing effect and even blocked the boosting effect of their full-length chemokine forms [211]. It must be noted that murine CCL3 resembles more to human 
CCL3L1 than to human CCL3 [212]. The activity of CD26 on the hematopoietic system was evidenced by showing that CD26 inhibition accelerated hematopoietic recovery after an episode of stress, such as after radiotherapy or chemotherapeutic drug treatment [213]. Treatment with sitagliptin in a small cohort of patients with hematological malignancies seemed to enhance engraftment of umbilical cord blood transplants, an established source of hematopoietic stem cells (HSCs) [214].

\subsubsection{Truncation by CD26 Sustains Chemokine Tumor-Promoting Activity CCL5}

Native CCL5 is also a substrate of CD26, which generates CCL5(3-68). This truncation induces a change in receptor specificity, with reduced affinity for CCR1 and CCR3, but similar affinity for CCR5 [215]. Whereas the chemotactic activity for T cells and M-CSFstimulated monocyte-derived macrophages was unchanged, the chemotactic response of monocytes and eosinophils towards truncated CCL5 was abolished [203]. Even an enhancement of T cell migration upon addition of sCD26 to both CCL5 forms was observed [216]. In vitro, CCL5(3-68) inhibited monocyte chemotaxis towards intact CCL5, CCL3, CCL4, and CCL7, but not CCL2 and CCL8 [217]. Interestingly, CCL5(3-68) was the predominant isoform purified from whole blood and sarcoma cells and was also found in vivo, where it was further processed to CCL5(4-68) [218]. Although experimental evidence of CD26truncated CCL5 isoforms in tumors is lacking, truncation most likely will not induce any major changes as lymphocytes and macrophages are equally activated by CCL5(3-68). Although the truncated isoform is less able to attract eosinophils and monocytes, it could not antagonize CCL2 in monocyte chemotaxis, which is a major monocyte attractant in cancer. Since the role of eosinophils in tumors is also limited, intact CCL5 or CD26-processed CCL5 isoforms would most likely instigate a similar effect on tumor progression.

\section{CCL3L1}

CD26 cleaves CCL3L1/LD78 $\beta$ at the penultimate proline into CCL3L1(3-70). This subverts intact CCL3L1(1-70), a strong CCR5 binder and inhibitor of HIV infection, into CCL3L1(3-70), an even more potent monocyte and lymphocyte chemoattractant. Moreover, CCL3L1(3-70) was considered the most potent chemokine in blocking HIV-1 infection in mononuclear cells. Receptor affinity for CCR 5 and CCR1 were also moderately and highly increased, respectively [219]. Truncated CCL3L1 even superseded CCL3 as the most potent CCR1 ligand. On the contrary, CCR3 affinity decreased compared to intact CCL3L1, which underlines the importance of the penultimate proline for CCR3 binding [220]. Information on the involvement of intact CCL3L1 in cancer is still scarce, but the role of the truncated chemokine will be similar to the intact form because the chemoattractant activity for inflammatory monocytes and lymphocytes via CCR1/CCR5 is rather increased.

\subsubsection{Truncation by CD26 Abrogates Chemokine Anti-Tumoral Activity CXCR3 Ligands}

All IFN-inducible CXCR3 ligands are $\mathrm{NH}_{2}$-terminally cleaved by $\mathrm{CD} 26$, albeit at different rates, e.g., within $2 \mathrm{~min} 50 \%$ of CXCL11 was cleaved, whereas this was 3 - and 10-fold slower for CXCL10 and CXCL9, respectively [221]. In general, CD26-mediated truncation generates isoforms with reduced affinity for the CXCR3A receptor and primarily affects the chemotactic capacities of the IFN-inducible CXCR3 ligands. CXCL10(3-77) and CXCL11(3-73) bound to CXCR3A with lower affinity and lost their calcium signaling capacities [222]. CXCL9(3-103) retained some of its weak activity to mobilize calcium and showed only minor reduction in receptor binding capacity. However, all three truncated IFN-inducible CXCR3 ligands lost their ability to chemoattract CXCR3 ${ }^{+} \mathrm{T}$ lymphocytes. CXCL10(3-77) and CXCL11(3-73) could partially desensitize CXCR3A in response to their parental counterpart in calcium signaling assays. In chemotaxis assays, truncated CXCL10 was a potent antagonist for intact CXCL10, but not intact CXCL11, which is a strong CXCR3A binder. Truncated CXCL11 inhibited the migratory response of CXCR3A- 
transfected and CXCR3 ${ }^{+} \mathrm{T}$ cells towards CXCL11(1-73) [222,223]. In contrast to lymphocyte trafficking, the angiostatic properties of the IFN-inducible CXCR3 ligands are not affected by CD26 clipping. Truncated CXCL9 and CXCL10 retained their ability to counteract CXCL8-induced angiogenesis in the rabbit cornea micropocket assay [222]. This indicates that the angiostatic activity of those CXCR3 ligands is not mediated through CXCR3A signaling or that intact and truncated CXCL9/10 activate separate CXCR3-mediated signaling cascades. Of note, it would be interesting to study the interaction of the CD26-truncated CXCR3 ligands with CXCR3B. Recently, CXCL10 has been identified as a ligand for ACKR2, which serves as a scavenger for mainly CC chemokines [224]. It was shown that upon truncation by CD26, CXCL10 had reduced activity towards ACKR2, which could have implications on the concentration of truncated CXCL10 in the extracellular space.

Although CXCL11 preserves its ability to suppress angiogenesis after CD26 truncation, in vivo, CXCL11 is further $\mathrm{NH}_{2}$-terminally processed. When tissue fibroblasts and peripheral blood-derived mononuclear leukocytes were stimulated with IFN- $\gamma$ and Toll-like receptor ligands, truncated forms of CXCL11 missing up to 6 amino acids were purified [225]. The consecutive cleavage of CXCL11 by CD26 and CD13, another protease implicated in the regulation of angiogenesis, resulted in CXCL11 forms without lymphotactic properties, such as CXCL11(3-73), CXCL11(5-73), and CXCL11(7-73). The shortest isoform, CXCL11(7-73), had inferior potential to inhibit the migration of HUVECs and as such lost part of its angiostatic properties. In addition, progressive CXCL11 $\mathrm{NH}_{2}$-terminal truncation reduced its affinity for ACKR3 (previously named CXCR7), a receptor that promotes cell adhesion, growth, and survival. As such, extensive CXCL11 truncation most likely impairs biological effects mediated by ACKR3. Interestingly, pharmacological inhibition of ACKR3 reduced growth of several tumors in vivo such as A549 lung carcinoma and mouse LLC, and prolonged survival in mice engrafted with human lymphoma IM9 cells [226]. Altogether, the tumor microenvironment created by $\mathrm{NH}_{2}$-terminal processed IFN-inducible CXCR3 ligands would be more immunotolerant and angiogenic, and therefore in favor of tumor progression.

CD26 truncation of IFN-inducible CXCR3 ligands in both preclinical cancer models and patients primarily affects anti-tumoral leukocyte and mainly lymphocyte infiltration (Figure 2). One report mentions the infiltration of pre-cDC1 cells, a specific subset of bone marrow-derived conventional DC progenitors, important in the anti-cancer response, that home to B16F10 melanoma tumors using CXCR3 [227]. Preservation of intact CXCR3 ligands via sitagliptin treatment improved $\mathrm{CDC} 1$ presence in tumors. In this model, CD26 was expressed on B and T cells, macrophages and DCs, but minimally on neutrophils and non-immune cells. CD26 inhibition in an immune-competent model of HCC also impaired tumor growth due to increased infiltration of $\mathrm{CXCR}^{+} \mathrm{NK}$ an T cells [228]. The observation that CD26 is upregulated on activated T cells could be a regulatory feedback mechanism to limit $\mathrm{CXCR}^{+}$lymphocyte infiltration, which is favorable in an inflammatory setting where the pro-inflammatory response has to be dampened, but unfavorable in a tumor setting where the host's immune defense has to be sustained [168,229].

Among the CXCR3 ligands, malignant progression is mostly reported to be favored by truncated CXCL10 isoforms, and therefore could be counteracted by CD26 inhibition. In several murine cancer models, inhibition of CD26 enhanced natural anti-tumoral lymphocyte response and efficacy of concomitant immunotherapy. In syngeneic CT26 colorectal cancer and B16F10 melanoma mouse models, sitagliptin treatment enhanced CD4 ${ }^{+}$and $\mathrm{CD} 8^{+} \mathrm{T}$ cell infiltration and reduced tumor growth and metastases due to preservation of the active CXCL10 form [230]. No major differences in tumor-infiltrating myeloid cells, NK cells, CD25+ Tregs, and B cells were observed. The combined use of sitagliptin, a programmed cell death protein-1 (PD-1) inhibitor and a CTLA-4 inhibitor enhanced the immunotherapy response. Recent studies identified different Th cell subsets depending on the intensity of CD26 expression. The authors reported CD26 $6^{\text {high }} \mathrm{T}$ cells (Th1/Th17), rather than CD26 $6^{\text {int }}$ (naive) and CD26 ${ }^{\text {neg }} \mathrm{T}$ cells (Th2, Treg) to persist via enhanced stemness and to induce tumor regression of multiple solid tumors through increased infiltration and 
cytotoxicity [231]. Two clinical trials were conducted to test the efficacy of sitagliptin in healthy volunteers and chronic HCV patients, in which CD26 levels are elevated. These underlined the in vivo relevance of CXCL10 processing by CD26 and supported the use of sitagliptin in different disease settings [232]. As a result of increased CD26 expression in HCV patients, both intact and truncated CXCL10(3-77) were detected in serum [233]. The authors hypothesized that the antagonistic properties of the CXCL10(3-77) isoform possibly correlated with treatment failure. In patients with serous epithelial ovarian tumors, the occurrence of cleaved CXCL10 was partially responsible for reduced recruitment of anti-tumoral leukocytes, and contributed to worse prognosis [234]. In non-muscle invasive bladder cancer, intravesical Bacille Calmette-Guérin (BCG) treatment is usually associated with an increase in pro-inflammatory cytokines and chemokines, such as CXCL10. Due to high levels of CD26 in urine, increased amounts of $\mathrm{NH}_{2}$-terminally cleaved CXCL10(3-77) were detected therein [233]. The processing might also limit recruitment of CXCR3 ${ }^{+} \mathrm{T}$ and NK cells to the bladder, which might protect the bladder mucosa, but would hamper therapeutic efficacy. As such, the use of CD26 inhibitors in patients receiving BCG treatment could enhance the anti-tumor response and/or shorten the treatment.

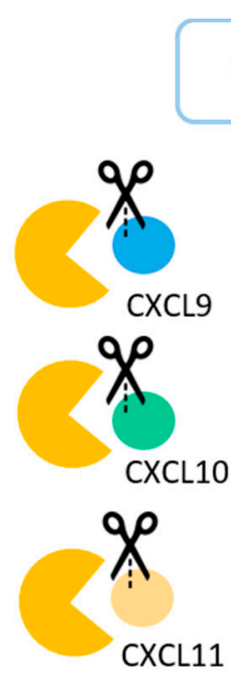

\section{CD26 upregulation $\uparrow$}

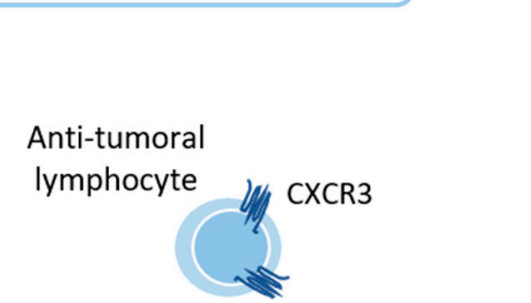

\section{CD26 downregulation $\downarrow$}

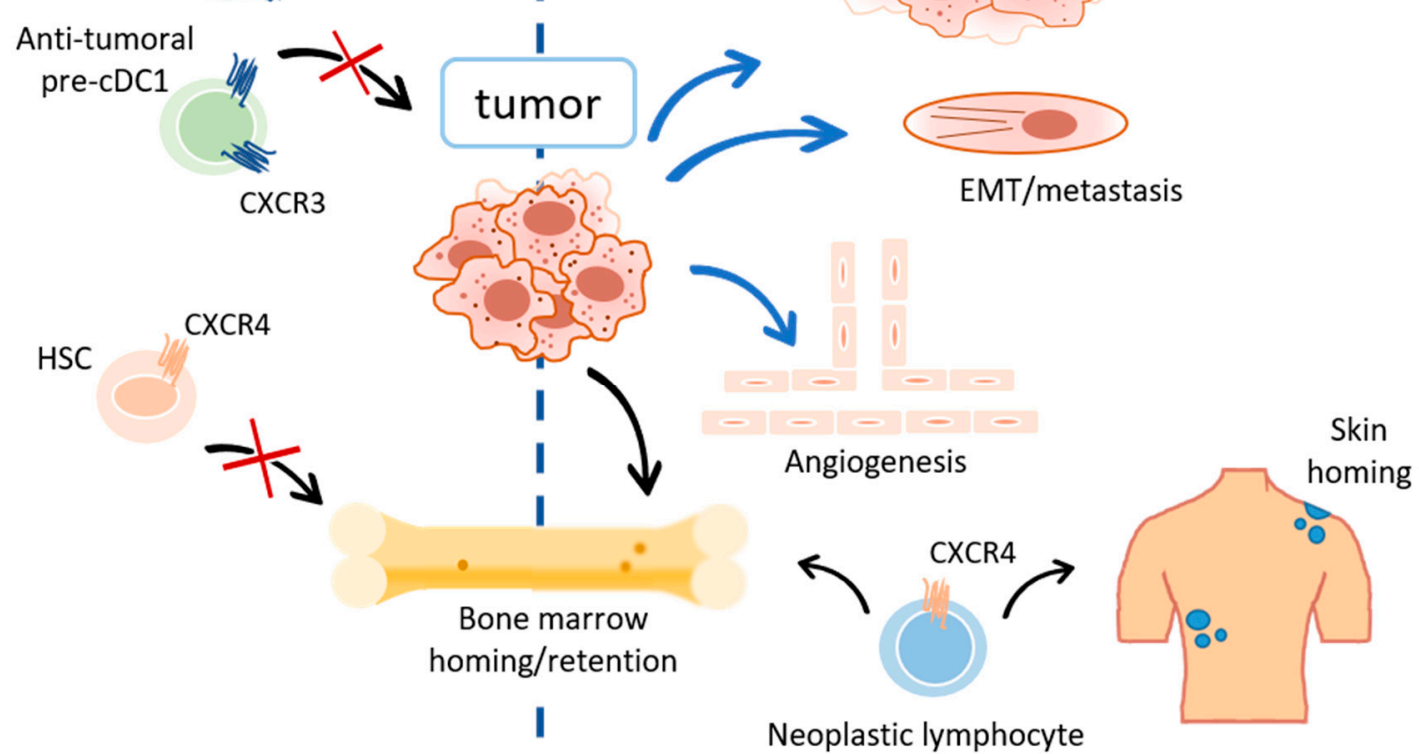

Figure 2. Overview of the pro-tumoral environment created by fine-tuning CD26 expression in relation to some of its chemokine substrates. Only chemokine substrates for which a clear effect of the interaction between CD26 and the chemokine on malignancy has been demonstrated are included. Depending on the tumor type, CD26 is either up- or downregulated, which influences the dominant chemokine isoform present in the tumor stroma. CD26-expressing tumors generate truncated IFN-inducible CXCR3 ligands CXCL9/10/11, which impacts anti-tumoral immune responses [lymphocyte and conventional type 1 dendritic cell progenitor (pre-cDC1)]. Truncated CXCL12 is associated with impaired hematopoietic stem cell (HSC) homing to the bone marrow. Tumors expressing low amounts of CD26 generate intact CXCL12 isoforms, which further steer the tumor towards progression via increased growth factor expression, induction of angiogenesis, epithelial to mesenchymal transition (EMT), metastasis, retention in or homing to the bone marrow and in case of T cell malignancies, accumulation of neoplastic T cells in the skin. Black arrows involve cell migration, blue arrows are used for other tumor-promoting processes. 


\section{CCL11}

CCL11 is a chemoattractant for eosinophils, acting via CCR3, and vulnerable to CD26 cleavage. Truncated CCL11 is characterized by a lower affinity for and impaired signaling through CCR3, reduced eosinophil chemotactic potency and CCR3 internalization [235]. CCL11(3-74) also acted as an antagonist for calcium signaling and chemotaxis in response to intact CCL11. These findings were further corroborated in vivo: CD26 deficiency or pharmacological inhibition of CD26 significantly enhanced CCL11-mediated eosinophil recruitment. Although unusual, eosinophilia in cancer has been associated with a more favorable prognosis in several human solid cancers, such as colon carcinoma and OSCC $[236,237]$. Eosinophils can directly affect tumor growth through cytotoxicity or indirectly by secretion of chemokines that promote $\mathrm{T}$ cell recruitment and macrophage polarization [238]. Administration of the CD26 inhibitor sitagliptin increased intratumoral (breast and liver) concentrations of IL-33 and CCL11 and the influx of eosinophils, supposedly by enhancing CCL11 gradients [239]. The CCL11/CCR3 axis has been associated with several hematological malignancies as well. Isolated fibroblasts from patients with Hodgkin lymphoma expressed high levels of CCL11, while the tumor cells expressed CCR3. In patients with CTCL [either mycosis fungoides (MF) or Sézary syndrome (SS)], serum concentrations of CCL11 and CCL17 were increased and correlated with disease activity [240].

\subsubsection{A CD26-Negative Tumor Milieu Preserves Chemokine Pro-Tumoral Activity CCL22}

Different from other chemokine substrates, CD26 consecutively cleaves the Gly1Pro2 and Tyr3-Gly4 dipeptides from CCL22 giving rise to CCL22(3-69) and CCL22(5-69), respectively. CCL22(3-69) was not chemotactic for T cells due to reduced affinity for and signaling through CCR4, but retained its ability to attract monocytes [241]. CCL22(5-69) showed reduced chemotactic activity on lymphocytes and monocyte-derived DCs, and impaired calcium mobilization through CCR4. However, both cleaved forms of CCL22 had similar chemotactic effects as intact CCL22 on monocytes [242]. Both CCL22 isoforms also lost their ability to interact with scavenging receptor ACKR2, which could affect trafficking of CCR4 ${ }^{+}$immune cells [243]. Although no direct evidence has been found yet in tumors, CD26-mediated cleavage of CCL22 could affect its primary function as CCR4 ${ }^{+}$ Treg recruiter and as such contribute to a tumor unfriendly environment. However, it is very plausible that a tumor microenvironment is created that promotes the presence of the intact form. In Sézary patients, leukemic $\mathrm{CD} 4^{+} \mathrm{CD} 26^{-}$lymphocytes were characterized by a selective high expression of CCR4 [244,245]. In accordance, chemokine levels of CCL17, CCL22, and CXCL10 in serum were concomitantly increased. Although evidence that CD26 downregulation preserved the intact CCL22 isoform was not provided, preservation of intact CCL22 in this setting could contribute to CCR4 ${ }^{+}$SS tumor cell accumulation in the skin [244-246].

\section{CXCL12}

By differential splicing from a single gene, CXCL12 exists in several isoforms, including CXCL12- $\alpha$ and CXCL12- $\beta$, which contains four additional amino acids at the $\mathrm{COOH}$-terminus compared to CXCL12- $\alpha$. Because of an $\mathrm{NH}_{2}$-terminal penultimate proline, both CXCL12 isoforms are direct substrates of CD26. Of note, the half-life of CXCL12- $\alpha$ in the presence of CD26 was less than $1 \mathrm{~min}$ [247]. $\mathrm{NH}_{2}$-terminal processing gives rise to two isoforms, CXCL12- $\alpha(3-68)$ and CXCL12- $\beta(3-72)$ with abrogated antiviral and T lymphotactic properties [247]. CXCL12- $\alpha(3-68)$ lost in addition to chemotactic, also its CXCR4 signaling properties, but had the ability to desensitize for intact CXCL12- $\alpha$-mediated CXCR4 signaling [248,249]. $\mathrm{NH}_{2}$-terminal residues (1-8) of CXCL12- $\alpha$ have been identified as critical for CXCR4 binding and activation. However, the $\mathrm{NH}_{2}$-terminus alone was not sufficient for binding and activation, and additional residues (12-17) were found necessary for CXCR4 docking. This could explain why the CXCL12- $\alpha(3-68)$ isoform still possessed 
some, albeit lower, affinity for CXCR4. Later studies confirmed that CXCL12- $\alpha(3-68)$ could no longer instigate inositol triphosphate $\left(\mathrm{IP}_{3}\right), \mathrm{Akt}, \mathrm{ERK}$, and $\beta$-arrestin signaling through $G$ proteins [250]. Beta-arrestin recruitment via the decoy receptor ACKR3 was reduced but remained. When endothelial cells were studied as target cells, CXCL12- $\alpha(3-68)$ was not able to induce migration or activate ERK and Akt signal transduction pathways. In vivo administration of intact and truncated CXCL12- $\alpha$ did not induce lymphocyte recruitment, but treatment with sitagliptin preserved the lymphotactic ability of the intact chemokine. Additionally, when exposed to CD26-expressing $\mathrm{T}$ cells, $\mathrm{NH}_{2}$-terminally processed forms of both CXCL12- $\alpha$ and CXCL12- $\beta$ were detected, which supported the idea that chemotactic activity on T lymphocytes in vivo might also be modulated by CD26. Moreover, in the presence of CXCL12- $\alpha$, CXCR4 is internalized together with CD26 in human T and B lymphocytes [251]. Since also soluble CD26 is able to inactivate CXCL12- $\alpha$, membranebound CD26 could regulate CXCL12 activity locally, whereas soluble CD26 could modulate chemokine activity in circulation [248].

In addition to its role as a lymphocyte recruiter, CXCL12- $\alpha$ functions as retention/migration signal for CD34 ${ }^{+}$HSCs and HPCs to the bone marrow [252] Notably, the bone marrow stroma was the first cellular source reported for CXCL12- $\alpha$ [253]. After truncation, CXCL12 failed to induce migration of $\mathrm{CD} 34^{+}$cord blood cells and acted as an antagonist of intact CXCL12. This has implications for HSC transplantation. Inhibition of the endogenous activity of $\mathrm{CD} 26$, present on a subpopulation of $\mathrm{CD} 34^{+} \mathrm{HSC}$, enhanced the migratory response of those cells to CXCL12 [254]. High levels of CD26 were also found in peripheral blood samples from breast cancer patients that were scheduled for autologous transplantation after mobilization with granulocyte-macrophage-colony-stimulating factor (GM-CSF) [255]. Some mobilized CD $34^{+}$cells showed CD26 expression and peptidase activity. For these patients, inhibition of CD26 could be a therapeutic approach to enhance stem cell homing during bone marrow transplantation.

Other reports on the involvement and consequences of CD26-mediated processing of CXCL12 in a tumor setting are rather scarce. However, although not surprising, they usually involve downregulation of CD26 and therefore preservation of intact CXCL12. This sustains and prolongs the pro-tumoral activity of CXCL12 on leukocytes, but mainly on stromal and tumor cells, which considerably favors tumor progression. Many of these reports are in accordance with the observed downregulation of CD26 in the types of cancer mentioned earlier (Figures 1 and 2). In prostate cancer, malignant progression of benign prostate hyperplasia to metastatic cancer is linked to an increased production of bFGF [256]. CD26 was shown to inhibit the malignant phenotype by suppressing the bFGF signaling pathway [194]. Differential CD26 expression in cancer was further evidenced in a 4T1 breast cancer model where tumor growth and metastasis were accelerated, rather than attenuated by pharmacological inhibition of CD26 [257]. When CD26 activity was reduced, CXCL12/CXCR4 signaling was enhanced and promoted EMT. Similarly, CD26 inhibition by diprotin A treatment facilitated invasion and metastasis of prostate cancer cells to the bone marrow in vivo [258]. A study in human breast carcinoma patients showed that increased TGF- $\beta$ and CXCL12 autocrine signaling of myofibroblastic CAFs attenuated CD26 expression and was associated with poor prognosis [196]. CXCL12/CXCR4 signaling has also been implicated in endometrial lesions that are characterized by a downmodulation of CD26 activity [208]. Moreover, both CD26 and CXCL12- $\alpha$ are downregulated in more advanced endometrial adenocarcinoma [259]. Modulation of CXCL12 by CD26 is additionally important in neuroblastoma. The enzyme is downmodulated on malignant neuroblastoma cells and reintroduction promoted cell differentiation and apoptosis [260]. Moreover, decreased CD26 expression preserved the CXCL12/CXCR4 expression and the activity of downstream pro-tumoral effectors Akt and MMP-9. The relevance of these in vitro findings was further demonstrated in vivo. CD26 suppressed tumor growth via induction of apoptosis and diminished angiogenesis in a xenotransplantation mouse model of neuroblastoma. 
Altered CD26 expression is observed in several forms of blood cancer, such as MF and SS, two rare forms of CTCL [261]. In SS patients, the impaired expression of CD26 on tumor cells was responsible for uncontrolled accumulation of $\mathrm{CXCR} 4^{+} \mathrm{T}$ cells in the skin where CXCL12 is abundantly expressed [262]. Primary myelofibrosis (PMF) is a chronic myeloproliferative neoplasm characterized by a continuous abnormal trafficking of HSCs and HPCs into the blood, which results in extramedullary hematopoiesis. This persistent mobilization is likely to result from a defect in CXCR4/CXCL12 signaling that normally retains HSCs/HPCs in the bone marrow [263]. In addition to downregulation of CXCR4 expression on CD34 ${ }^{+}$PMF cells, increased levels of several CXCL12 isoforms were found in the plasma and marrow of PMF patients compared to healthy individuals [264]. Degradation of CXCL12 was attributed to the sequential actions of CD26, neutrophil elastase (NE), MMP-2, and MMP-9. One study mentions the favorable increase in CD26 expression in a colorectal cancer metastasis model. Treatment of orthotopic HT-29 xenografts with conventional chemotherapeutic agents resulted in a decrease in CXCR4 and increase in CD26 tumor expression, which abrogated chemotaxis towards CXCL12 [265]. Thus, in parallel with exerting cytotoxicity, chemotherapy may also abrogate CXCL12/CXCR4 signaling. An overview of known chemokine substrates of CD26, their function and the effect upon CD26 processing in cancer is displayed in Table 1.

Table 1. Overview of chemokine function and processing by CD26 in cancer.

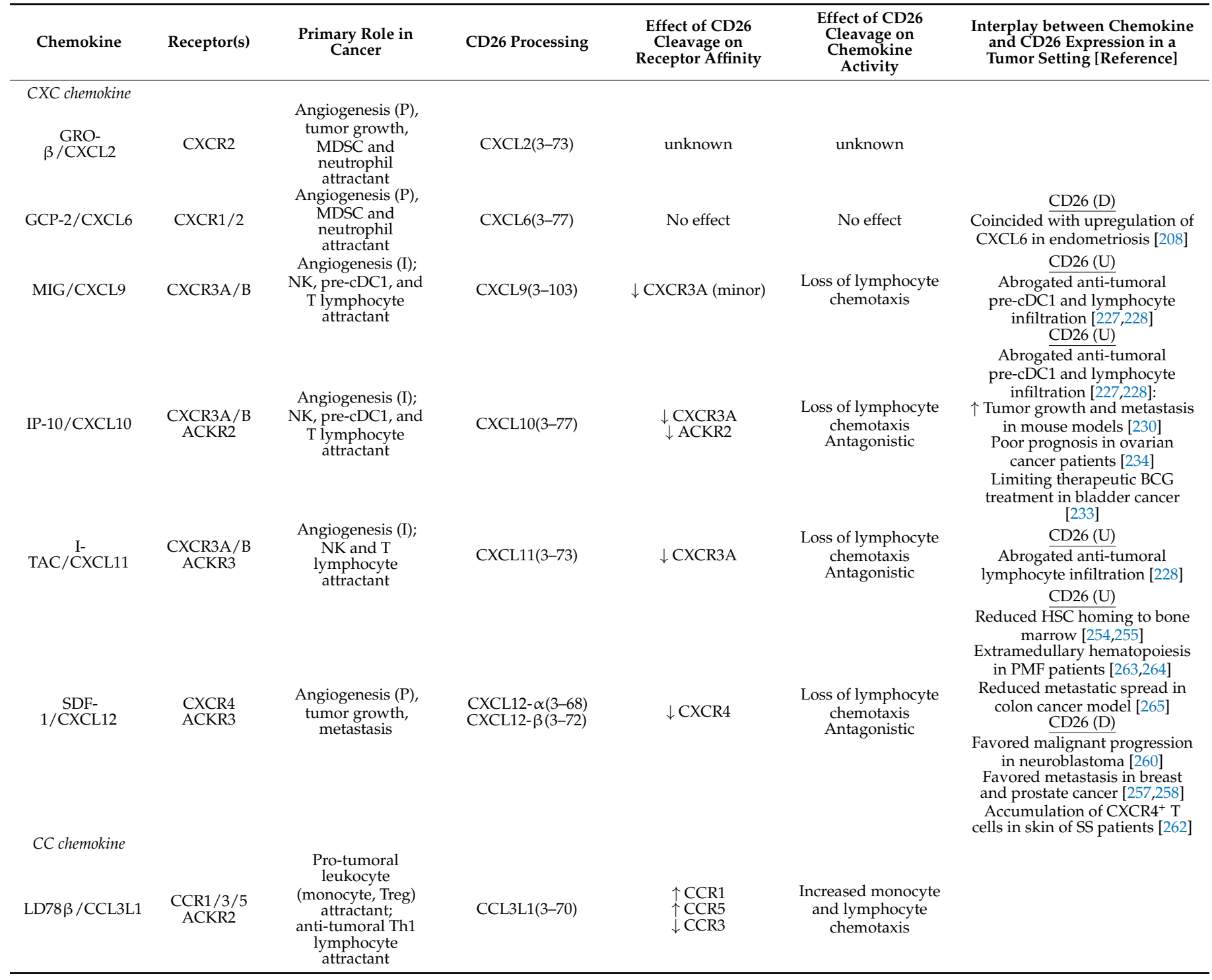


Table 1. Cont.

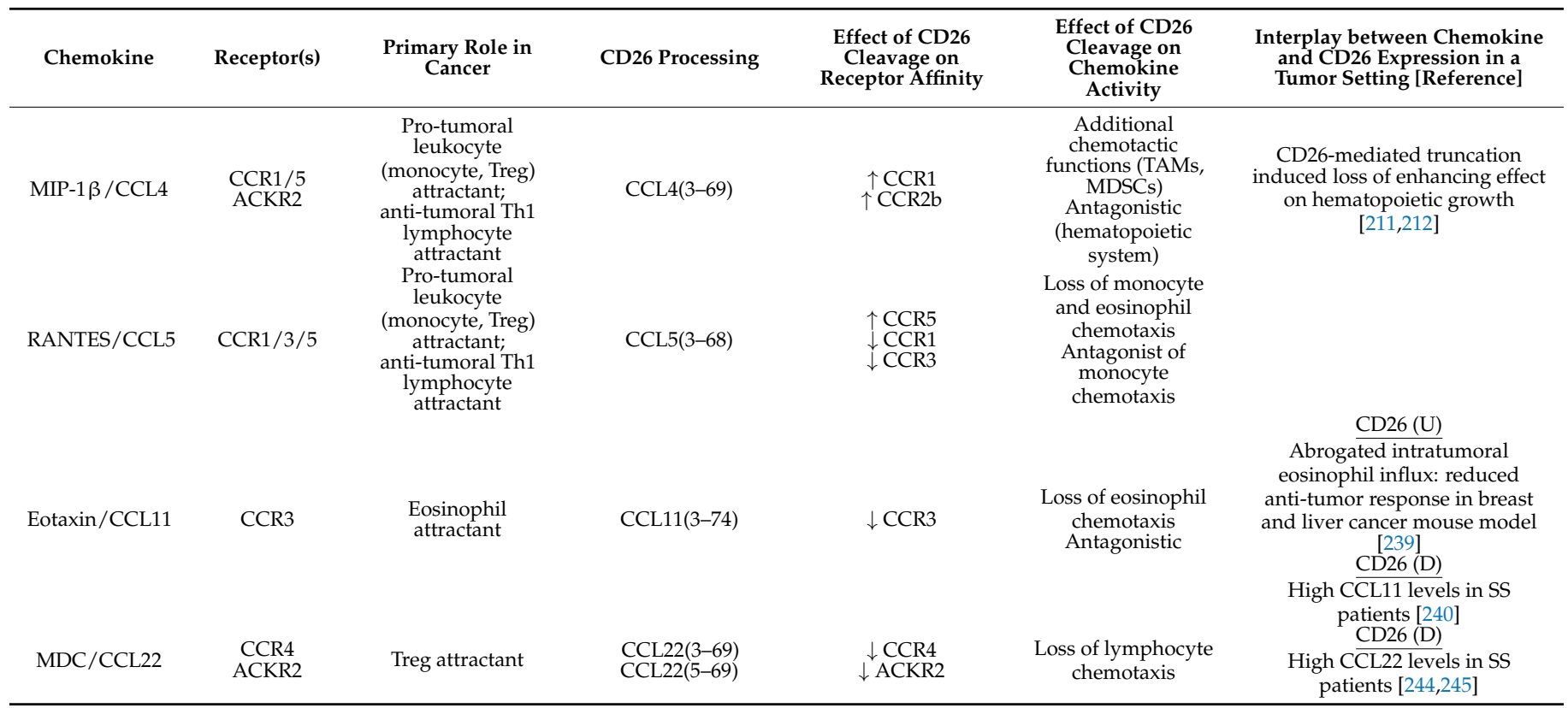

$\downarrow$, decreased; $\uparrow$, enhanced; ACKR, atypical chemokine receptor; BCG, Bacille Calmette-Guérin; CXCL and CCL, CXC and CC chemokine ligand; CXCR and CCR, CXC and CC chemokine receptor; D, downregulation; HSC, hematopoietic stem cell; I, inhibiting; MDSC, myeloidderived suppressor cell; NK, natural killer cell; pre-cDC1, conventional type 1 dendritic cell progenitor; PMF, primary myelofibrosis; $\mathrm{P}$, promoting; SS, Sézary syndrome; TAM, tumor-associated macrophage; Th, T helper; Treg, regulatory T cell; U, upregulation.

\subsection{Protection against CD26-Mediated Cleavage}

Aside from $\mathrm{CD} 26, \mathrm{NH}_{2}$-terminal and $\mathrm{COOH}$-terminal processing of chemokines by other proteases is far from uncommon. A mechanism by which chemokines are protected against proteolytic cleavage is through other post-translational modifications. For example, MCP chemokines CCL2, CCL7, and CCL8 are protected from CD26 truncation due to cyclization of the $\mathrm{NH}_{2}$-terminal glutamine into pyroglutamate. A CCL8 variant with an $\mathrm{NH}_{2}$-terminal lysine instead of pyroglutamate was readily truncated by CD26 and showed reduced chemotactic ability after cleavage. As such, the $\mathrm{NH}_{2}$-terminal pyroglutamate is necessary for CCL8 chemotactic activity and protects against CD26-mediated degradation [266]. Some chemokines have the tendency to oligomerize, which also confers some degree of protection. CXC chemokines often dimerize into structures resembling the CXCL8 dimer by interactions between residues in the first $\beta$-strand, while CC chemokines (e.g., CCL2) often dimerize into elongated structures [267]. Certain chemokines are also able to form higher order oligomers. For example, CXCL4 forms a tetramer and CCL3, CCL4, and CCL5 form large oligomers in solution. Moreover, glycosaminoglycan (GAG)induced oligomerization of CCL5 is necessary for its in vivo function [268]. The stability of the monomers, dimers or oligomers largely depends on the environmental conditions and the presence of stabilizing agents (ion, GAGs, etc.). CCL3/4/5 oligomers are very stable as large oligomers, but CXCL12 and CCL2 shift more readily between monomer and dimer when the solution conditions are changed [269-271]. Higher order oligomers are formed by chemokines themselves or upon binding to GAGs. The importance of GAGs in chemokine stability was underlined in a study where upon intraperitoneal (i.p.) administration, [ $\left.{ }^{44} \mathrm{AANA}^{47}\right]$-CCL5, a CCL5 isoform with abrogated GAG-binding properties, was rapidly released in the bloodstream and $\mathrm{NH}_{2}$-terminally truncated with a peak concentration in serum 30 min post-i.p. injection [218]. Chemokine-GAG interactions protect several chemokines against CD26 cleavage, as has been shown for CXCL12 and the IFN-inducible CXCR3 ligands CXCL9/10/11 [272,273]. The kinetics of chemokine half-life in the presence of CD26 (in a physiological salt buffer in the absence of GAGs) from slow to rapid truncation are as follows: CCL3L1 > CCL5 > CCL11 > CXCL9 > CXCL10 > CXCL11 > CCL22 > CXCL12 [221,274]. 


\subsection{Effect on the Interaction between Cleaved Chemokine Products and GAGs}

In order to properly exert their function in vivo, chemokines need to interact with both their respective GPCR and with GAGs. GAGs are long, linear, negatively charged polysaccharides (due to sulfate and carboxylate groups) that primarily electrostatically interact with basic residues in protein structures. In terms of chemokine function, GAGs enable the formation of a chemokine gradient along and through the endothelium that allows the directional recruitment of leukocytes. Two GAG-binding motifs have been described in chemokines, namely BBXB and BBBXXBBX with $B$ a basic amino acid and $X$ any non-basic amino acid. While the chemokine receptor-binding region of chemokines is known to reside in the $\mathrm{N}$-loop and $\mathrm{NH}_{2}$-terminal residues, for some chemokines, residues in the $\mathrm{COOH}$-terminal domain mediate GAG binding [275]. However, a significant overlap between the receptor and GAG-binding domain has been reported for CCL2, CCL3, CCL5, CXCL1, CXCL5, and CXCL10 [276-281]. The CXC chemokines CXCL8 and CXCL12 have GAG-binding sites in the 20s loop, which was long thought to be only part of the receptorbinding domain, while for the CC chemokines CCL3/4 the 40s loop and for CCL5 the BBXB motif in the 40s loop participates in GAG binding [278]. A cluster of basic residues Lys24His25-Lys27 and Arg41 in CXCL12 was reported to provide surface charge to complement the negatively charged $\mathrm{COOH}$-terminal tail and contribute to heparan sulfate binding [282]. Furthermore, the CCL5 isoform $\left[{ }^{44} \mathrm{AANA}{ }^{47}\right]$-CCL 5 lost its ability to chemoattract CCR ${ }^{+}$ monocytes due to the absence of CCR1 binding and additionally showed abrogated heparin binding. Moreover, naturally occurring deimination of arginine at position 5 in CXCL10 into citrulline reduced ( $\mathrm{T}$ cell) chemoattracting, CXCR3 signaling capacities, and GAGbinding properties [283]. Citrulinated CXCL11 showed similar characteristics, albeit to a lesser extent. As lysines, arginines, and histidines confer the chemokine with positive charges, deimination leads to the loss of 1 positive charge in the $\mathrm{NH}_{2}$-terminus. In addition, some studies have reported that the XCL1 chemokine exists in two forms: the classical chemokine-like fold which only binds its XCR1 receptor and a $\beta$-sheet fold, which only binds to GAGs [284]. Altogether, these findings further underline the overlap in these two function-defining regions of chemokines. This led to a recent reconceptualization of the chemokine-receptor-GAG interaction that stipulates that the chemokine-receptor and chemokine-GAG interactions cannot take place simultaneously.

CD26- and CD13-mediated cleavage of CXCL11 to CXCL11(5-73) results in a CXCR3 antagonist with increased affinity for heparin [285]. Moreover, this form is also characterized by a loss of angiostatic activity. Further MMP-mediated COOH-terminal truncation to amino acid 58 abolishes CXCR3 antagonistic function and heparin binding. CD26-mediated production of CXCL12- $\alpha(3-68)$ resulted in reduced affinity for heparin and dermatan sulfate, but similar affinity for heparan sulfate [250]. As such, CD26 cleavage of CXCL12- $\alpha$ does affect GAG binding. Exposure of CXCL12- $\alpha(1-68)$ to the serum generates products CXCL12- $\alpha(1-67)$ and CXCL12- $\alpha(3-67)$ through $\mathrm{COOH}$ - and CD26 $\mathrm{NH}_{2}$-terminal processing, respectively. CXCL12- $\beta(1-72)$ is only processed at the $\mathrm{NH}_{2}$-terminus to generate CXCL12- $\beta(3-72)$. The absence of the COOH-terminal lysine in CXCL12- $\alpha(1-67)$ leads to decreased affinity for heparin and a 2-fold reduction in potency compared to CXCL12$\beta$ [286]. Consecutive $\mathrm{NH}_{2}$-terminal cleavage to CXCL12- $\alpha(3-67)$ is further associated with markedly reduced heparin binding affinity [287].

\section{Strategies Based on Specific Chemokine Sequences in Cancer Therapy}

Proteolytically modified chemokines can in theory either be beneficial or detrimental for cancer evolution. In practice, however, the tumor microenvironment will promote the presence of those chemokine isoforms that will be the most favorable for the tumor mass to sustain and progress. This is reflected in CD26 down- or upregulation depending on the tumor type and on the primordial chemokine axis involved. Similar to CD26mediated processing that often generates chemokine antagonists, efforts have been made to identify inhibitory chemokine-derived peptides based on specific regions within the chemokine structure. This sequence-based approach has led to the development of several 
peptides derived from chemokine sequences or chemokine-related sequences to be used in a therapeutic setting. Several of such strategies will be discussed below.

\subsection{CXCL4- and CXCL4L1-Derived Peptides}

When the inhibitory actions of peptides corresponding to different CXCL4 domains were studied, it was revealed that a peptide containing heparin-binding lysine-rich motifs and comprising amino acids 47 to 70 of CXCL4 inhibited VEGF and bFGF activity [288]. CXCL4- and CXCL4L1-derived COOH-terminal peptides CXCL4 $4^{47-70}$ and CXCL4L1 ${ }^{47-70}$ were shown to lack in vitro monocyte and lymphocyte chemotactic properties, but retained their angiostatic activity [289]. CXCL4 ${ }^{47-70}$ associated with greater affinity to heparin than CXCL4L1 $1^{47-70}$, but neither peptides interacted with the CXCR3 receptor [70]. In concordance to the effects of the parental molecules, CXCL4L1 ${ }^{47-70}$ was a more potent in vitro and in vivo angiostatic than CXCL4 ${ }^{47-70}$. The CXCL4L1-derived peptide attenuated tumor growth in a B16 melanoma model via apoptosis and inhibition of angiogenesis. CXCL4 ${ }^{47-70}$ and CXCL4L1 ${ }^{47-70}$ also attenuated proliferation of MDA-MB-231 tumor cells and lymphatic and vascular endothelial cells [290]. Only the COOH-terminal fragment of CXCL4 decreased MDA-MB-231 tumor growth, not through inhibition of angiogenesis but rather by eliciting an anti-tumoral immune response and by inhibiting tumor cell proliferation. CXCL4 ${ }^{47-70}$ treatment also delayed glioma recurrence in mice after surgical resection and improved survival [291]. Lastly, an $\mathrm{NH}_{2}$-terminally extended isoform of CXCL4L1 with 4 additional amino acids, namely CXCL4L1(-4-70), was isolated from thrombinstimulated platelets [292]. Although $\mathrm{NH}_{2}$-terminal modifications can result in drastic changes in chemokine activity, this CXCL4L1 isoform retained its angiostatic activity.

\subsection{CXCL12-Derived Peptides}

The importance of the CXCL12/CXCR4 axis in cancer has been extensively shown, which translates in a number of approaches to target this axis. A 17 amino acid peptide dimer derived from the CXCL12 $\mathrm{NH}_{2}$-terminus, CTCE-9908 (KGVSLSYR-K-NH2KGVSLSYR), that antagonizes CXCR4, was developed, and its efficacy was exhibited in several studies. The CXCL12 peptide dimer was shown to inhibit migration, and upon increasing concentrations, induced cell death by mitotic catastrophe of CXCR4-expressing ovarian cancer cells [293]. In two mouse models of breast cancer, both primary tumor burden and distant metastasis were reduced upon CTCE-9908 treatment [294]. Combined CTCE-9908 and docetaxel or anti-VEGFR2 monoclonal antibody treatment in the PyMT breast cancer model also enhanced the anti-tumor and anti-metastatic effect compared to single treatment with anti-VEGFR2 or docetaxel [295]. Angiogenesis, infiltration of MDSCs, and metastasis to liver and spleen was also reduced in a prostate cancer mouse model $[296,297]$. CTCE-9908 already received FDA approval for the treatment of osteogenic sarcoma. A phase I/II clinical trial in patients with advanced solid tumors such as breast, ovarian, lung, and skin tumors showed that the anti-cancer agent was well tolerated and showed preliminary signs of efficacy, especially in ovarian cancer patients [298].

Chemokine-derived peptides can also be used for targeted gene delivery. In a study comparing several peptides, a long CXCL12-derived peptide, ranging from the CXCL12 $\mathrm{NH}_{2}$-terminal domain to the RFFESH domain important in receptor binding (KPVSLSYRSPSRFFESH-K9-biotin) was a more likely candidate for targeting CXCR4expressing cells compared to a short CXCL12-derived peptide comprising only the $\mathrm{NH}_{2}$ terminal domain (KPVSLSYR-K9-biotin) [299]. It was discovered later that the presence of the K9 spacer compromised gene delivery due to instability in physiological conditions. Therefore, modifications were installed, creating the peptide KPVSLSYRSPSRFFESH-AhxAhx-CHRRRRRRHC as a modular peptide for siRNA delivery [300]. CHRRRRRRHC was synthesized as an unmodified control peptide. Via template polymerization, a modular carrier was created, comprising $50 \%$ of the ligand-modified and $50 \%$ of the control peptide. Anti-VEGF-A siRNA delivery via this carrier peptide decreased VEGF-A expression in endothelial and glioblastoma cells and inhibited endothelial cell migration. 


\subsection{CCL5-Derived Peptide}

The $\mathrm{NH}_{2}$-terminus of CCL 5 can be modified either by (1) recombinant expression of CCL5 in E. Coli, which results in a product where the initiating $\mathrm{NH}_{2}$-terminal methionine is retained (Met-CCL5) or by (2) the chemical coupling of a pentacarbon alkyl chain (AOP-CCL5). This gives rise to two CCL5-derived isoforms with in vitro antagonistic properties in the nanomolar range [301,302]. AOP-CCL5 was the most potent inhibitor of HIV infection mediated by CCR5, but was less effective on CCR1 and CCR3. Met-CCL5 elicited a weak calcium response via CCR1/3/5, but was shown to significantly reduce inflammatory symptoms in several models of inflammation [303]. Met-CCL5 also had a higher affinity for heparan sulfate [304]. Transplantation of 410.4 breast cancer carcinoma cells in BALB/c expressing high levels of CCL5 resulted in the attraction of CCR1- and CCR5-expressing CD8 ${ }^{+} \mathrm{T}$ cells, macrophages, and neutrophils [305]. Treatment with MetCCL5 decelerated tumor growth and macrophage infiltration. Met-CCL5 also reduced the invasion of $4 \mathrm{~T} 1$ breast cancer cells in response to CCL5-containing conditioned media of D1 mesenchymal stem cells [306].

\subsection{CXCL1-Derived Peptide}

A bioinformatic analysis to identify endogenous angiostatic peptides, identified six short peptides derived from the $\mathrm{COOH}$-terminus of $\mathrm{ELR}^{+}$angiogenic chemokines (CXCL1/3/5/6/7/8) [307]. These peptides showed sequence similarities to CXCL4 and all inhibited HUVEC proliferation and VEGF-induced migration. Three angiostatic peptides, identified through the same methodology and derived from either type IV collagen, CXCL1, or a thrombospondin domain-containing protein were tested in an in vivo MDA-MB-231 breast cancer model [308]. Chemokinostatin-1, the CXCL1-derived peptide, was previously shown to inhibit endothelial activity, but did not inhibit breast tumor cell or fibroblast proliferation. In vivo administration reduced the number of $\mathrm{CD} 31^{+}$vessels and attenuated tumor growth until day 13, after which tumor resistance to the peptide-based treatment occurred. Later studies showed that chemokinostatin-1 reduced HUVEC tube formation and tumor volume in a U87 human glioma xenograft model [309].

\subsection{Chimeric CXCL10/CXCL11 Chemokine}

To improve the anti-tumor effects of two individual chemokines, i.e., CXCL10 and CXCL11, their individual functional moieties were merged into a chimeric chemokine, termed ITIP [310]. ITIP consists of the $\mathrm{NH}_{2}$-terminal and $\mathrm{NH}_{2}$-loop region of CXCL11 and the COOH-terminal region of CXCL10. CXCL10 is a more potent inhibitor of neovessel formation, but CXCL11 supersedes it in the attraction of anti-tumoral T lymphocytes. The chimeric molecule had superior anti-tumorigenic activity compared to its parental chemokines separately or combined due to the dual action of the individual functional CXCL10 and CXCL11 residues. ITIP induced tumor regression and prolonged survival in CT26 colon and 4T1 mammary carcinoma mouse models causing reduced microvessel density and increased $\mathrm{T}$ lymphocyte infiltration.

\subsection{Pepducins}

Cell-penetrating pepducins are lipidated peptides that act intracellularly and block signaling between the GPCRs and their G protein effectors. Pepducins based on the first (i1) or third (i3) intracellular loop of CXCR1 and CXCR2 receptors are potent antagonists of both receptors [311]. The x1/2pal-i3 pepducin based on the third intracellular loop of CXCR1 and CXCR2 was first shown to inhibit endothelial activation (proliferation and tube formation) by CXCL8 and CXCL1. These chemokines are known to be released by ovarian carcinoma cells to stimulate angiogenesis [312]. The in vitro findings were confirmed in vivo: the $x 1 / 2$ pal-i3 pepducin also inhibited tumor growth and angiogenesis in a mouse model of ovarian cancer. 


\subsection{Spiegelmers}

Spiegelmers are selective and high affinity target-binding structures of non-natural L-nucleotides [313]. The mirror image configuration confers these structures with plasma stability and immunological passivity. Several spiegelmers have been developed so far, such as a CXCL12-targeting spiegelmer conjugated with polyethyleneglycol (PEG), named olaptesed pegol or NOX-A12. NOX-A12 was developed to interfere with CXCL12 in the tumor microenvironment and in cell mobilization. CXCL12 is an essential retention and homing signal for highly CXCR4-expressing chronic lymphocytic leukemia (CLL) cells in tissues such as the bone marrow. Therein, stromal cells constitutively produce CXCL12, which is presented via surface-bound GAGs. This attracts CLL cells and confers protection from cytotoxic drugs, which might be responsible for residual disease after conventional therapy. Studies using NOX-A12 found that the spiegelmer could compete with CXCL12 for GAG binding, which resulted in the release and subsequent neutralization of CXCL12 [314]. As such, CXCL12-induced CLL retention in the bone marrow was inhibited and sensitivity to chemotherapy enhanced. NOX-A12-mediated CXCL12 neutralization also delays or prevents multiple myeloma (MM) dissemination to the bone marrow, which is one of the main causes of death associated with MM [315]. NOX-A12 was deemed safe in healthy volunteers and went into Phase Ila clinical studies in patients with refractory CLL or MM in combination with conventional therapy $[313,316]$. Patients with glioblastoma often deal with resistance to anti-angiogenic therapy due to hypoxia and CXCL12-mediated recruitment of TAMs. When rats bearing glioblastoma multiforme were treated with a combination of anti-VEGF antibodies and NOX-A12, CXCL12 blockade enhanced the effect of anti-VEGF therapy by inhibiting TAM recruitment and further reducing the tumor microvasculature [317]. Additionally, in a mouse model of colorectal cancer, NOX-A12 treatment could abrogate CXCL12-mediated immune suppression and enhance T and NK cell infiltration which improved anti-PD-1 therapy [318].

\section{Conclusions}

$\mathrm{NH}_{2}$-terminal clipping of chemokines by CD26 entails an important post-translational modification that affects and regulates chemokine activity. Chemokines are broadly involved in tumor progression, but CD26 has a certain degree of selectivity in terms of chemokine substrate. Some chemokines are protected from CD26-mediated cleavage by the presence of specific amino acid residues. Others can escape clipping through oligomerization or binding to cellular GAGs. In addition to impacting GPCR receptor activation, CD26mediated processing can also affect chemokine-GAG interactions, and thereby chemokine stability in circulation and thus in vivo half-life. In cancer, CD26 most likely has the most profound effect on the functional properties of CXCL12 and IFN-inducible CXCR3 ligands, who are converted into receptor antagonists upon truncation. Antagonistic actions are favorable for pro-tumoral CXCL12, but unfavorable for anti-tumoral CXCL9/10/11. However, the tumor microenvironment is often cunning through differential CD26 expression depending on the cancer type. This can accommodate preferential generation of the chemokine product whose action is most favorable for tumor progression. Studying the effect of chemokine processing uncovered chemokine structure/activity relationships and revealed that different chemokine properties reside in different regions of the chemokine structure. This knowledge can be exploited to chemically engineer molecules with proper characteristics to target cancer-related processes and can therefore possibly be used in a therapeutic setting.

Author Contributions: A.D.Z. wrote the initial manuscript which was corrected and modified by S.S. and J.V.D. The manuscript was finally revised by all authors. All authors have read and agreed to the published version of the manuscript.

Funding: This work was funded by the Research Foundation-Flanders (FWO-Vlaanderen) (grant G0D2517N) and a C1 grant (C16/17/010) from KU Leuven. ADZ obtained a PhD fellowship supported by the FWO-Vlaanderen. 
Conflicts of Interest: The authors declare no conflict of interest with the contents of this article.

\section{References}

1. Bottazzi, B.; Polentarutti, N.; Acero, R.; Balsari, A.; Boraschi, D.; Ghezzi, P.; Salmona, M.; Mantovani, A. Regulation of the macrophage content of neoplasms by chemoattractants. Science 1983, 220, 210-212. [CrossRef]

2. Lazennec, G.; Richmond, A. Chemokines and chemokine receptors: New insights into cancer-related inflammation. Trends Mol. Med. 2010, 16, 133-144. [CrossRef] [PubMed]

3. Zlotnik, A.; Yoshie, O.; Nomiyama, H. The chemokine and chemokine receptor superfamilies and their molecular evolution. Genome Biol. 2006, 7, 243. [CrossRef] [PubMed]

4. Keane, M.P.; Belperio, J.A.; Xue, Y.Y.; Burdick, M.D.; Strieter, R.M. Depletion of CXCR2 Inhibits Tumor Growth and Angiogenesis in a Murine Model of Lung Cancer. J. Immunol. 2004, 172, 2853-2860. [CrossRef]

5. Addison, C.L.; Daniel, T.O.; Burdick, M.D.; Liu, H.; Ehlert, J.E.; Xue, Y.Y.; Buechi, L.; Walz, A.; Richmond, A.; Strieter, R.M. The CXC Chemokine Receptor 2, CXCR2, Is the Putative Receptor for ELR+CXC Chemokine-Induced Angiogenic Activity. J. Immunol. 2000, 165, 5269-5277. [CrossRef] [PubMed]

6. Wuyts, A.; Proost, P.; Lenaerts, J.-P.; Ben-Baruch, A.; Van Damme, J.; Wang, J.M. Differential usage of the CXC chemokine receptors 1 and 2 by interleukin-8, granulocyte chemotactic protein-2 and epithelial-cell-derived neutrophil attractant-78. J. Biol. Inorg. Chem. 1998, 255, 67-73. [CrossRef] [PubMed]

7. Rossi, D.; Zlotnik, A. The Biology of Chemokines and their Receptors. Annu. Rev. Immunol. 2000, 18, 217-242. [CrossRef]

8. Kasashima, H.; Yashiro, M.; Nakamae, H.; Kitayama, K.; Masuda, G.; Kinoshita, H.; Fukuoka, T.; Hasegawa, T.; Nakane, T.; Hino, M.; et al. CXCL1-Chemokine (C-X-C Motif) Receptor 2 Signaling Stimulates the Recruitment of Bone Marrow-Derived Mesenchymal Cells into Diffuse-Type Gastric Cancer Stroma. Am. J. Pathol. 2016, 186, 3028-3039. [CrossRef]

9. Yamamoto, Y.; Kuroda, K.; Sera, T.; Sugimoto, A.; Kushiyama, S.; Nishimura, S.; Togano, S.; Okuno, T.; Yoshii, M.; Tamura, T.; et al. The Clinicopathological Significance of the CXCR2 Ligands, CXCL1, CXCL2, CXCL3, CXCL5, CXCL6, CXCL7, and CXCL8 in Gastric Cancer. Anticancer. Res. 2019, 39, 6645-6652. [CrossRef]

10. Romero-Moreno, R.; Curtis, K.J.; Coughlin, T.R.; Miranda-Vergara, M.C.; Dutta, S.; Natarajan, A.; Facchine, B.A.; Jackson, K.M.; Nystrom, L.; Li, J.; et al. The CXCL5/CXCR2 axis is sufficient to promote breast cancer colonization during bone metastasis. Nat. Commun. 2019, 10, 4404. [CrossRef]

11. Boissière-Michot, F.; Jacot, W.; Massol, O.; Mollevi, C.; Lazennec, G. CXCR2 Levels Correlate with Immune Infiltration and a Better Prognosis of Triple-Negative Breast Cancers. Cancers 2021, 13, 2328. [CrossRef]

12. Boissière-Michot, F.; Jacot, W.; Fraisse, J.; Gourgou, S.; Timaxian, C.; Lazennec, G. Prognostic Value of CXCR2 in Breast Cancer. Cancers 2020, 12, 2076. [CrossRef] [PubMed]

13. Teijeira, Á.; Garasa, S.; Gato, M.; Alfaro, C.; Migueliz, I.; Cirella, A.; de Andrea, C.; Ochoa, M.C.; Otano, I.; Etxeberria, I.; et al. CXCR1 and CXCR2 Chemokine Receptor Agonists Produced by Tumors Induce Neutrophil Extracellular Traps that Interfere with Immune Cytotoxicity. Immunity 2020, 52, 856-871.e8. [CrossRef] [PubMed]

14. Sano, M.; Ijichi, H.; Takahashi, R.; Miyabayashi, K.; Fujiwara, H.; Yamada, T.; Kato, H.; Nakatsuka, T.; Tanaka, Y.; Tateishi, K.; et al. Blocking CXCLs-CXCR2 axis in tumor-stromal interactions contributes to survival in a mouse model of pancreatic ductal adenocarcinoma through reduced cell invasion/migration and a shift of immune-inflammatory microenvironment. Oncogenesis 2019, 8, 8. [CrossRef] [PubMed]

15. Timaxian, C.; Vogel, C.; Orcel, C.; Vetter, D.; Durochat, C.; Chinal, C.; Nguyen, P.; Aknin, M.-L.; Mercier-Nomé, F.; Davy, M.; et al. Pivotal Role for Cxcr2 in Regulating Tumor-Associated Neutrophil in Breast Cancer. Cancers 2021, 13, 2584. [CrossRef] [PubMed]

16. Clark-Lewis, I.; Dewald, B.; Geiser, T.; Moser, B.; Baggiolini, M. Platelet factor 4 binds to interleukin 8 receptors and activates neutrophils when its N terminus is modified with Glu-Leu-Arg. Proc. Natl. Acad. Sci. USA 1993, 90, 3574-3577. [CrossRef] [PubMed]

17. Dean, R.A.; Cox, J.H.; Bellac, C.L.; Doucet, A.; Starr, A.E.; Overall, C.M. Macrophage-specific metalloelastase (MMP-12) truncates and inactivates ELR+ CXC chemokines and generates CCL2, $-7,-8$, and -13 antagonists: Potential role of the macrophage in terminating polymorphonuclear leukocyte influx. Blood 2008, 112, 3455-3464. [CrossRef]

18. Clark-Lewis, I.; Schumacher, C.; Baggiolini, M.; Moser, B. Structure-activity relationships of interleukin-8 determined using chemically synthesized analogs. Critical role of $\mathrm{NH}_{2}$-terminal residues and evidence for uncoupling of neutrophil chemotaxis, exocytosis, and receptor binding activities. J. Biol. Chem. 1991, 266, 23128-23134. [CrossRef]

19. Bordoni, R.; Fine, R.; Murray, D.; Richmond, A. Characterization of the role of melanoma growth stimulatory activity (MGSA) in the growth of normal melanocytes, nevocytes, and malignant melanocytes. J. Cell. Biochem. 1990, 44, 207-219. [CrossRef] [PubMed]

20. Norgauer, J.; Metzner, B.; Schraufstätter, I. Expression and growth-promoting function of the IL-8 receptor beta in human melanoma cells. J. Immunol. 1996, 156, 1132-1137. [PubMed]

21. Takamori, H.; Oades, Z.G.; Hoch, R.C.; Burger, M.; Schraufstatter, I.U. Autocrine Growth Effect of IL-8 and GRO $\alpha$ on a Human Pancreatic Cancer Cell Line, Capan-1. Pancreas 2000, 21, 52-56. [CrossRef]

22. Owen, J.D.; Strieter, R.; Burdick, M.; Haghnegahdar, H.; Nanney, L.; Shattuck-Brandt, R.; Richmond, A. Enhanced tumor-forming capacity for immortalized melanocytes expressing melanoma growth stimulatory activity/growth-regulated cytokine beta and gamma proteins. Int. J. Cancer 1997, 73, 94-103. [CrossRef] 
23. Taki, M.; Abiko, K.; Baba, T.; Hamanishi, J.; Yamaguchi, K.; Murakami, R.; Yamanoi, K.; Horikawa, N.; Hosoe, Y.; Nakamura, E.; et al. Snail promotes ovarian cancer progression by recruiting myeloid-derived suppressor cells via CXCR2 ligand upregulation. Nat. Commun. 2018, 9, 1685. [CrossRef] [PubMed]

24. SenGupta, S.; Hein, L.E.; Xu, Y.; Zhang, J.; Konwerski, J.R.; Li, Y.; Johnson, C.; Cai, D.; Smith, J.L.; Parent, C.A. TripleNegative Breast Cancer Cells Recruit Neutrophils by Secreting TGF- $\beta$ and CXCR2 Ligands. Front. Immunol. 2021, $12,659996$. [CrossRef] [PubMed]

25. Ciummo, S.L.; D'Antonio, L.; Sorrentino, C.; Fieni, C.; Lanuti, P.; Stassi, G.; Todaro, M.; Di Carlo, E. The C-X-C Motif Chemokine Ligand 1 Sustains Breast Cancer Stem Cell Self-Renewal and Promotes Tumor Progression and Immune Escape Programs. Front. Cell Dev. Biol. 2021, 9, 689286. [CrossRef] [PubMed]

26. Walz, A.; Burgener, R.; Car, B.; Baggiolini, M.; Kunkel, S.L.; Strieter, R.M. Structure and neutrophil-activating properties of a novel inflammatory peptide (ENA-78) with homology to interleukin 8. J. Exp. Med. 1991, 174, 1355-1362. [CrossRef]

27. Arenberg, D.; Keane, M.P.; DiGiovine, B.; Kunkel, S.L.; Morris, S.B.; Xue, Y.Y.; Burdick, M.D.; Glass, M.C.; Iannettoni, M.D.; Strieter, R.M. Epithelial-neutrophil activating peptide (ENA-78) is an important angiogenic factor in non-small cell lung cancer. $J$. Clin. Investig. 1998, 102, 465-472. [CrossRef] [PubMed]

28. Najjar, Y.G.; Rayman, P.; Jia, X.; Pavicic, P.G., Jr.; Rini, B.I.; Tannenbaum, C.; Ko, J.; Haywood, S.; Cohen, P.; Hamilton, T.; et al. Myeloid-Derived Suppressor Cell Subset Accumulation in Renal Cell Carcinoma Parenchyma Is Associated with Intratumoral Expression of IL1 $\beta$, IL8, CXCL5, and Mip-1 $\alpha$. Clin. Cancer Res. 2017, 23, 2346-2355. [CrossRef] [PubMed]

29. Zhou, S.-L.; Dai, Z.; Zhou, Z.-J.; Wang, X.-Y.; Yang, G.-H.; Wang, Z.; Huang, X.-W.; Fan, J.; Zhou, J. Overexpression of CXCL5 mediates neutrophil infiltration and indicates poor prognosis for hepatocellular carcinoma. Hepatology 2012, 56, 2242-2254. [CrossRef] [PubMed]

30. A López-Lago, M.; Posner, S.; Thodima, V.J.; Molina, A.M.; Motzer, R.; Chaganti, R.S.K. Neutrophil chemokines secreted by tumor cells mount a lung antimetastatic response during renal cell carcinoma progression. Oncogene 2013, 32, 1752-1760. [CrossRef]

31. Proost, P.; De Wolf-Peeters, C.; Conings, R.; Opdenakker, G.; Billiau, A.; Van Damme, J. Identification of a novel granulocyte chemotactic protein (GCP-2) from human tumor cells. In vitro and in vivo comparison with natural forms of GRO, IP-10, and IL-8. J. Immunol. 1993, 150, 1000-1010.

32. Van Damme, J.; Wuyts, A.; Froyen, G.; Van Coillie, E.; Struyf, S.; Billiau, A.; Proost, P.; Wang, J.M.; Opdenakker, G. Granulocyte chemotactic protein-2 and related CXC chemokines: From gene regulation to receptor usage. J. Leukoc. Biol. 1997, 62, 563-569. [CrossRef]

33. Strieter, R.M.; Polverini, P.J.; Kunkel, S.L.; Arenberg, D.; Burdick, M.D.; Kasper, J.; Dzuiba, J.; Van Damme, J.; Walz, A.; Marriott, D.; et al. The Functional Role of the ELR Motif in CXC Chemokine-mediated Angiogenesis. J. Biol. Chem. 1995, 270, 27348-27357. [CrossRef]

34. Gijsbers, K.; Gouwy, M.; Struyf, S.; Wuyts, A.; Proost, P.; Opdenakker, G.; Penninckx, F.; Ectors, N.; Geboes, K.; Van Damme, J. GCP-2/CXCL6 synergizes with other endothelial cell-derived chemokines in neutrophil mobilization and is associated with angiogenesis in gastrointestinal tumors. Exp. Cell Res. 2005, 303, 331-342. [CrossRef] [PubMed]

35. Van Coillie, E.; Van Aelst, I.; Wuyts, A.; Vercauteren, R.; Devos, R.; De Wolf-Peeters, C.; Van Damme, J.; Opdenakker, G. Tumor Angiogenesis Induced by Granulocyte Chemotactic Protein-2 as a Countercurrent Principle. Am. J. Pathol. 2001, 159, 1405-1414. [CrossRef]

36. Verbeke, H.; Struyf, S.; Berghmans, N.; Van Coillie, E.; Opdenakker, G.; Uyttenhove, C.; Van Snick, J.; Van Damme, J. Isotypic neutralizing antibodies against mouse GCP-2/CXCL6 inhibit melanoma growth and metastasis. Cancer Lett. 2011, $302,54-62$. [CrossRef] [PubMed]

37. Cohen, A.B.; Stevens, M.D.; Miller, E.J.; Atkinson, M.A.; Mullenbach, G. Generation of the neutrophil-activating peptide-2 by cathepsin G and cathepsin G-treated human platelets. Am. J. Physiol. Content 1992, 263, 249-256. [CrossRef] [PubMed]

38. Grépin, R.; Guyot, M.; Giuliano, S.; Boncompagni, M.; Ambrosetti, D.; Chamorey, E.; Scoazec, J.Y.; Negrier, S.; Simonnet, H.; Pages, G. The CXCL7/CXCR1/2 axis is a key driver in the growth of clear cell renal cell carcinoma. Cancer Res. 2014, 74, 873-883. [CrossRef]

39. Kinouchi, T.; Uemura, M.; Wang, C.; Ishizuya, Y.; Yamamoto, Y.; Hayashi, T.; Matsuzaki, K.; Nakata, W.; Yoshida, T.; Jingushi, K.; et al. Expression level of CXCL7 in peripheral blood cells is a potential biomarker for the diagnosis of renal cell carcinoma. Cancer Sci. 2017, 108, 2495-2502. [CrossRef] [PubMed]

40. Du, Q.; Li, E.; Liu, Y.; Xie, W.; Huang, C.; Song, J.; Zhang, W.; Zheng, Y.; Wang, H.; Wang, Q. CTAPIII/CXCL7: A novel biomarker for early diagnosis of lung cancer. Cancer Med. 2018, 7, 325-335. [CrossRef]

41. Li, L.; Zhang, L.; Tian, Y.; Zhang, T.; Duan, G.; Liu, Y.; Yin, Y.; Hua, D.; Qi, X.; Mao, Y. Serum Chemokine CXCL7 as a Diagnostic Biomarker for Colorectal Cancer. Front. Oncol. 2019, 9, 921. [CrossRef]

42. Desurmont, T.; Skrypek, N.; Duhamel, A.; Jonckheere, N.; Millet, G.; Leteurtre, E.; Gosset, P.; Duchêne, B.; Ramdane, N.; Hebbar, M.; et al. Overexpression of chemokine receptor CXCR2 and ligand CXCL7 in liver metastases from colon cancer is correlated to shorter disease-free and overall survival. Cancer Sci. 2015, 106, 262-269. [CrossRef] [PubMed]

43. Strieter, R.; Kunkel, S.; Showell, H.; Marks, R. Monokine-induced gene expression of a human endothelial cell-derived neutrophil chemotactic factor. Biochem. Biophys. Res. Commun. 1988, 156, 1340-1345. [CrossRef]

44. Kwon, O.J.; Au, B.T.; Collins, P.D.; Adcock, I.M.; Mak, J.C.; Robbins, R.R.; Chung, K.F.; Barnes, P.J. Tumor necrosis factor-induced interleukin-8 expression in cultured human airway epithelial cells. Am. J. Physiol. Content 1994, 267, 398-405. [CrossRef] [PubMed] 
45. Peveri, P.; Walz, A.; Dewald, B.; Baggiolini, M. A novel neutrophil-activating factor produced by human mononuclear phagocytes. J. Exp. Med. 1988, 167, 1547-1559. [CrossRef] [PubMed]

46. Van Damme, J.; Beeumen, J.; Conings, R.; Decock, B.; Billiau, A. Purification of granulocyte chemotactic peptide/interleukin-8 reveals N-terminal sequence heterogeneity similar to that of beta-thromboglobulin. J. Biol. Inorg. Chem. 1989, 181, 337-344. [CrossRef]

47. Varney, M.L.; Johansson, S.L.; Singh, R.K. Distinct expression of CXCL8 and its receptors CXCR1 and CXCR2 and their association with vessel density and aggressiveness in malignant melanoma. Am. J. Clin. Pathol. 2006, 125, 209-216. [CrossRef]

48. Strieter, R.M.; Kunkel, S.L.; Elner, V.M.; Martonyi, C.L.; Koch, A.E.; Polverini, P.J.; Elner, S.G. Interleukin-8. A corneal factor that induces neovascularization. Am. J. Pathol. 1992, 141, 1279-1284.

49. Heidemann, J.; Ogawa, H.; Dwinell, M.B.; Rafiee, P.; Maaser, C.; Gockel, H.R.; Otterson, M.F.; Ota, D.M.; Lügering, N.; Domschke, W.; et al. Angiogenic Effects of Interleukin 8 (CXCL8) in Human Intestinal Microvascular Endothelial Cells Are Mediated by CXCR2. J. Biol. Chem. 2003, 278, 8508-8515. [CrossRef]

50. Kitadai, Y.; Haruma, K.; Sumii, K.; Yamamoto, S.; Ue, T.; Yokozaki, H.; Yasui, W.; Ohmoto, Y.; Kajiyama, G.; Fidler, I.J.; et al. Expression of interleukin-8 correlates with vascularity in human gastric carcinomas. Am. J. Pathol. 1998, 152, 93-100.

51. Powell, D.; Lou, M.; Becker, F.B.; Huttenlocher, A. Cxcr1 mediates recruitment of neutrophils and supports proliferation of tumor-initiating astrocytes in vivo. Sci. Rep. 2018, 8, 13285. [CrossRef] [PubMed]

52. Ogawa, R.; Yamamoto, T.; Hirai, H.; Hanada, K.; Kiyasu, Y.; Nishikawa, G.; Mizuno, R.; Inamoto, S.; Itatani, Y.; Sakai, Y.; et al. Loss of SMAD4 Promotes Colorectal Cancer Progression by Recruiting Tumor-Associated Neutrophils via the CXCL1/8-CXCR2 Axis. Clin. Cancer Res. 2019, 25, 2887-2899. [CrossRef]

53. Brandolini, L.; Cristiano, L.; Fidoamore, A.; De Pizzol, M.; Di Giacomo, E.; Florio, T.M.; Confalone, G.; Galante, A.; Cinque, B.; Benedetti, E.; et al. Targeting CXCR1 on breast cancer stem cells: Signaling pathways and clinical application modelling. Oncotarget 2015, 6, 43375-43394. [CrossRef] [PubMed]

54. Bates, R.C.; DeLeo, M.J.; Mercurio, A.M. The epithelial-mesenchymal transition of colon carcinoma involves expression of IL-8 and CXCR-1-mediated chemotaxis. Exp. Cell Res. 2004, 299, 315-324. [CrossRef]

55. Fernando, R.I.; Castillo, M.D.; Litzinger, M.; Hamilton, D.H.; Palena, C. IL-8 Signaling Plays a Critical Role in the EpithelialMesenchymal Transition of Human Carcinoma Cells. Cancer Res. 2011, 71, 5296-5306. [CrossRef] [PubMed]

56. Salcedo, R.; Oppenheim, J.J. Role of chemokines in angiogenesis: CXCL12/SDF-1 and CXCR4 interaction, a key regulator of endothelial cell responses. Microcirculation 2003, 10, 359-370. [CrossRef] [PubMed]

57. Domańska, U.; Kruizinga, R.C.; Nagengast, W.B.; Timmer-Bosscha, H.; Huls, G.; de Vries, E.; Walenkamp, A.M. A review on CXCR4/CXCL12 axis in oncology: No place to hide. Eur. J. Cancer 2013, 49, 219-230. [CrossRef] [PubMed]

58. Barbero, S.; Bonavia, R.; Bajetto, A.; Porcile, C.; Pirani, P.; Ravetti, J.L.; Zona, G.L.; Spaziante, R.; Florio, T.; Schettini, G. Stromal cell-derived factor 1alpha stimulates human glioblastoma cell growth through the activation of both extracellular signal-regulated kinases $1 / 2$ and Akt. Cancer Res. 2003, 63, 1969-1974.

59. Orimo, A.; Gupta, P.B.; Sgroi, D.C.; Arenzana-Seisdedos, F.; Delaunay, T.; Naeem, R.; Carey, V.J.; Richardson, A.L.; Weinberg, R.A. Stromal Fibroblasts Present in Invasive Human Breast Carcinomas Promote Tumor Growth and Angiogenesis through Elevated SDF-1/CXCL12 Secretion. Cell 2005, 121, 335-348. [CrossRef] [PubMed]

60. Scotton, C.J.; Wilson, J.L.; Scott, K.; Stamp, G.; Wilbanks, G.D.; Fricker, S.; Bridger, G.; Balkwill, F.R. Multiple actions of the chemokine CXCL12 on epithelial tumor cells in human ovarian cancer. Cancer Res. 2002, 62, 5930-5938.

61. Tachibana, K.; Hirota, S.; Iizasa, H.; Yoshida, H.; Kawabata, K.; Kataoka, Y.; Kitamura, Y.; Matsushima, K.; Yoshida, N.; Nishikawa, S.-I.; et al. The chemokine receptor CXCR4 is essential for vascularization of the gastrointestinal tract. Nat. Cell Biol. 1998, 393, 591-594. [CrossRef] [PubMed]

62. Salcedo, R.; Wasserman, K.; Young, H.A.; Grimm, M.C.; Howard, O.Z.; Anver, M.R.; Kleinman, H.K.; Murphy, W.J.; Oppenheim, J.J. Vascular endothelial growth factor and basic fibroblast growth factor induce expression of CXCR4 on human endothelial cells: In vivo neovascularization induced by stromal-derived factor-1alpha. Am. J. Pathol. 1999, 154, 1125-1135. [CrossRef]

63. Darash-Yahana, M.; Pikarsky, E.; Abramovitch, R.; Zeira, E.; Pal, B.; Karplus, R.; Beider, K.; Avniel, S.; Kasem, S.; Galun, E.; et al. Role of high expression levels of CXCR4 in tumor growth, vascularization, and metastasis. FASEB J. 2004, 18, 1240-1242. [CrossRef]

64. Müller, A.; Homey, B.; Soto, H.; Ge, N.; Catron, D.; Buchanan, M.E.; McClanahan, T.; Murphy, E.; Yuan, W.; Wagner, S.N.; et al. Involvement of chemokine receptors in breast cancer metastasis. Nature 2001, 410, 50-56. [CrossRef] [PubMed]

65. Taichman, R.S.; Cooper, C.; Keller, E.T.; Pienta, K.J.; Taichman, N.S.; McCauley, L.K. Use of the stromal cell-derived factor1/CXCR4 pathway in prostate cancer metastasis to bone. Cancer Res. 2002, 62, 1832-1837.

66. Havens, A.M.; Jung, Y.; Sun, Y.X.; Wang, J.; Shah, R.B.; Bühring, H.J.; Pienta, K.; Taichman, R.S. The role of sialomucin CD164 (MGC-24v or endolyn) in prostate cancer metastasis. BMC Cancer 2006, 6, 195. [CrossRef]

67. Gil, M.; Komorowski, M.P.; Seshadri, M.; Rokita, H.; McGray, A.J.R.; Opyrchal, M.; Odunsi, K.O.; Kozbor, D. CXCL12/CXCR4 Blockade by Oncolytic Virotherapy Inhibits Ovarian Cancer Growth by Decreasing Immunosuppression and Targeting CancerInitiating Cells. J. Immunol. 2014, 193, 5327-5337. [CrossRef]

68. Givel, A.-M.; Kieffer, Y.; Scholer-Dahirel, A.; Sirven, P.; Cardon, M.; Pelon, F.; Magagna, I.; Gentric, G.; Costa, A.; Bonneau, C.; et al. miR200-regulated CXCL12 $\beta$ promotes fibroblast heterogeneity and immunosuppression in ovarian cancers. Nat. Commun. 2018, 9, 1056. [CrossRef] 
69. Feig, C.; Jones, J.O.; Kraman, M.; Wells, R.J.B.; Deonarine, A.; Chan, D.S.; Connell, C.M.; Roberts, E.; Zhao, Q.; Caballero, O.L.; et al. Targeting CXCL12 from FAP-expressing carcinoma-associated fibroblasts synergizes with anti-PD-L1 immunotherapy in pancreatic cancer. Proc. Natl. Acad. Sci. USA 2013, 110, 20212-20217. [CrossRef]

70. Maione, T.; Gray, G.; Petro, J.; Hunt, A.; Donner, A.; Bauer, S.; Carson, H.; Sharpe, R. Inhibition of angiogenesis by recombinant human platelet factor-4 and related peptides. Science 1990, 247, 77-79. [CrossRef]

71. Sharpe, R.J.; Byers, H.R.; Scott, C.F.; Bauer, S.I.; Maione, T.E. Growth Inhibition of Murine Melanoma and Human Colon Carcinoma by Recombinant Human Platelet Factor 4. J. Natl. Cancer Inst. 1990, 82, 848-853. [CrossRef]

72. Tanaka, T.; Manome, Y.; Wen, P.; Kufe, D.W.; Fine, H.A. Viral vector-mediated transduction of a modified platelet factor 4 cDNA inhibits angiogenesis and tumor growth. Nat. Med. 1997, 3, 437-442. [CrossRef] [PubMed]

73. Perollet, C.; Han, Z.C.; Savona, C.; Caen, J.P.; Bikfalvi, A. Platelet factor 4 modulates fibroblast growth factor 2 (FGF-2) activity and inhibits FGF-2 dimerization. Blood 1998, 91, 3289-3299. [CrossRef] [PubMed]

74. Gengrinovitch, S.; Greenberg, S.M.; Cohen, T.; Gitay-Goren, H.; Rockwell, P.; Maione, T.E.; Levi, B.-Z.; Neufeld, G. Platelet Factor-4 Inhibits the Mitogenic Activity of VEGF121 and VEGF165 Using Several Concurrent Mechanisms. J. Biol. Chem. 1995, 270, 15059-15065. [CrossRef] [PubMed]

75. Deng, S.; Deng, Q.; Zhang, Y.; Ye, H.; Yu, X.; Zhang, Y.; Han, G.Y.; Luo, P.; Wu, M.; Yu, Y.; et al. Non-platelet-derived CXCL4 differentially regulates cytotoxic and regulatory $\mathrm{T}$ cells through CXCR3 to suppress the immune response to colon cancer. Cancer Lett. 2019, 443, 1-12. [CrossRef] [PubMed]

76. Kuo, J.H.; Chen, Y.P.; Liu, J.S.; Dubrac, A.; Quemener, C.; Prats, H.; Bikfalvi, A.; Wu, W.G.; Sue, S.C. Alternative C-terminal helix orientation alters chemokine function: Structure of the anti-angiogenic chemokine, CXCL4L1. J. Biol. Chem. 2013, 288, 13522-13533. [CrossRef]

77. Struyf, S.; Burdick, M.D.; Proost, P.; Van Damme, J.; Strieter, R.M. Platelets Release CXCL4L1, a Nonallelic Variant of the Chemokine Platelet Factor-4/CXCL4 and Potent Inhibitor of Angiogenesis. Circ. Res. 2004, 95, 855-857. [CrossRef] [PubMed]

78. Struyf, S.; Salogni, L.; Burdick, M.D.; Vandercappellen, J.; Gouwy, M.; Noppen, S.; Proost, P.; Opdenakker, G.; Parmentier, M.; Gerard, C.; et al. Angiostatic and chemotactic activities of the CXC chemokine CXCL4L1 (platelet factor-4 variant) are mediated by CXCR3. Blood 2011, 117, 480-488. [CrossRef]

79. Vandercappellen, J.; Noppen, S.; Verbeke, H.; Put, W.; Conings, R.; Gouwy, M.; Schutyser, E.; Proost, P.; Sciot, R.; Geboes, K.; et al. Stimulation of angiostatic platelet factor-4 variant (CXCL4L1/PF-4var) versus inhibition of angiogenic granulocyte chemotactic protein-2 (CXCL6/GCP-2) in normal and tumoral mesenchymal cells. J. Leukoc. Biol. 2007, 82, 1519-1530. [CrossRef]

80. Struyf, S.; Burdick, M.D.; Peeters, E.; Broeck, K.V.D.; Dillen, C.; Proost, P.; Van Damme, J.; Strieter, R.M. Platelet Factor-4 Variant Chemokine CXCL4L1 Inhibits Melanoma and Lung Carcinoma Growth and Metastasis by Preventing Angiogenesis. Cancer Res. 2007, 67, 5940-5948. [CrossRef]

81. Van Raemdonck, K.; Gouwy, M.; Lepers, S.A.; Van Damme, J.; Struyf, S. CXCL4L1 and CXCL4 signaling in human lymphatic and microvascular endothelial cells and activated lymphocytes: Involvement of mitogen-activated protein (MAP) kinases, Src and p70S6 kinase. Angiogenesis 2014, 17, 631-640. [CrossRef]

82. Lasagni, L.; Francalanci, M.; Annunziato, F.; Lazzeri, E.; Giannini, S.; Cosmi, L.; Sagrinati, C.; Mazzinghi, B.; Orlando, C.; Maggi, E.; et al. An Alternatively Spliced Variant of CXCR3 Mediates the Inhibition of Endothelial Cell Growth Induced by IP-10, Mig, and I-TAC, and Acts as Functional Receptor for Platelet Factor 4. J. Exp. Med. 2003, 197, 1537-1549. [CrossRef]

83. Strieter, R.M.; Belperio, J.A.; Phillips, R.J.; Keane, M.P. CXC chemokines in angiogenesis of cancer. Semin. Cancer Biol. 2004, 14, 195-200. [CrossRef]

84. Angiolillo, A.L.; Sgadari, C.; Taub, D.D.; Liao, F.; Farber, J.M.; Maheshwari, S.; Kleinman, H.K.; Reaman, G.H.; Tosato, G. Human interferon-inducible protein 10 is a potent inhibitor of angiogenesis in vivo. J. Exp. Med. 1995, 182, 155-162. [CrossRef] [PubMed]

85. Arenberg, D.; Kunkel, S.L.; Polverini, P.J.; Morris, S.B.; Burdick, M.D.; Glass, M.C.; Taub, D.T.; Iannettoni, M.D.; I Whyte, R.; Strieter, R.M. Interferon-gamma-inducible protein 10 (IP-10) is an angiostatic factor that inhibits human non-small cell lung cancer (NSCLC) tumorigenesis and spontaneous metastases. J. Exp. Med. 1996, 184, 981-992. [CrossRef] [PubMed]

86. Bronger, H.; Magdolen, V.; Goettig, P.; Dreyer, T. Proteolytic chemokine cleavage as a regulator of lymphocytic infiltration in solid tumors. Cancer Metastasis Rev. 2019, 38, 417-430. [CrossRef] [PubMed]

87. Kondo, T.; Nakazawa, H.; Ito, F.; Hashimoto, Y.; Osaka, Y.; Futatsuyama, K.; Toma, H.; Tanabe, K. Favorable prognosis of renal cell carcinoma with increased expression of chemokines associated with a Th1-type immune response. Cancer Sci. 2006, 97, 780-786. [CrossRef] [PubMed]

88. Harlin, H.; Meng, Y.; Peterson, A.C.; Zha, Y.; Tretiakova, M.; Slingluff, C.; McKee, M.; Gajewski, T.F. Chemokine Expression in Melanoma Metastases Associated with CD8+ T-Cell Recruitment. Cancer Res. 2009, 69, 3077-3085. [CrossRef]

89. Mullins, I.M.; Slingluff, C.L.; Lee, J.K.; Garbee, C.F.; Shu, J.; Anderson, S.G.; Mayer, M.E.; Knaus, W.A.; Mullins, D. CXC Chemokine Receptor 3 Expression by Activated CD8+ T cells Is Associated with Survival in Melanoma Patients with Stage III Disease. Cancer Res. 2004, 64, 7697-7701. [CrossRef]

90. Mlecnik, B.; Tosolini, M.; Charoentong, P.; Kirilovsky, A.; Bindea, G.; Berger, A.; Camus, M.; Gillard, M.; Bruneval, P.; Fridman, W.H.; et al. Biomolecular Network Reconstruction Identifies T-Cell Homing Factors Associated With Survival in Colorectal Cancer. Gastroenterology 2010, 138, 1429-1440. [CrossRef] 
91. Walser, T.C.; Rifat, S.; Ma, X.; Kundu, N.; Ward, C.; Goloubeva, O.; Johnson, M.G.; Medina, J.C.; Collins, T.L.; Fulton, A.M. Antagonism of CXCR3 Inhibits Lung Metastasis in a Murine Model of Metastatic Breast Cancer. Cancer Res. 2006, 66, 7701-7707. [CrossRef] [PubMed]

92. Kawada, K.; Hosogi, H.; Sonoshita, M.; Sakashita, H.; Manabe, T.; Shimahara, Y.; Sakai, Y.; Takabayashi, A.; Oshima, M.; Taketo, M.M. Chemokine receptor CXCR3 promotes colon cancer metastasis to lymph nodes. Oncogene 2007, 26, 4679-4688. [CrossRef] [PubMed]

93. Cambien, B.; Karimdjee, B.F.; Richard-Fiardo, P.; Bziouech, H.; Barthel, R.; Millet, M.A.; Martini, V.; Birnbaum, D.; Scoazec, J.Y.; Abello, J.; et al. Organ-specific inhibition of metastatic colon carcinoma by CXCR3 antagonism. Br. J. Cancer 2009, 100, 1755-1764. [CrossRef] [PubMed]

94. Doron, H.; Amer, M.; Ershaid, N.; Blazquez, R.; Shani, O.; Lahav, T.G.; Cohen, N.; Adler, O.; Hakim, Z.; Pozzi, S.; et al. Inflammatory Activation of Astrocytes Facilitates Melanoma Brain Tropism via the CXCL10-CXCR3 Signaling Axis. Cell Rep. 2019, 28, 1785-1798.e6. [CrossRef] [PubMed]

95. Legler, D.F.; Loetscher, M.; Roos, R.S.; Clark-Lewis, I.; Baggiolini, M.; Moser, B. B Cell-attracting Chemokine 1, a Human CXC Chemokine Expressed in Lymphoid Tissues, Selectively Attracts B Lymphocytes via BLR1/CXCR5. J. Exp. Med. 1998, 187, 655-660. [CrossRef]

96. Gu-Trantien, C.; Migliori, E.; Buisseret, L.; De Wind, A.; Brohée, S.; Garaud, S.; Noël, G.; Chi, V.L.D.; Lodewyckx, J.N.J.; Naveaux, C.C.; et al. CXCL13-producing TFH cells link immune suppression and adaptive memory in human breast cancer. JCI Insight 2017, 2. [CrossRef] [PubMed]

97. Bindea, G.; Mlecnik, B.; Tosolini, M.; Kirilovsky, A.; Waldner, M.; Obenauf, A.; Angell, H.; Fredriksen, T.; Lafontaine, L.; Berger, A.; et al. Spatiotemporal Dynamics of Intratumoral Immune Cells Reveal the Immune Landscape in Human Cancer. Immunity 2013, 39, 782-795. [CrossRef]

98. Ma, C.; Han, M.; Heinrich, B.; Fu, Q.; Zhang, Q.; Sandhu, M.; Agdashian, D.; Terabe, M.; Berzofsky, J.A.; Fako, V.; et al. Gut microbiome-mediated bile acid metabolism regulates liver cancer via NKT cells. Science 2018, 360, eaan5931. [CrossRef]

99. Korbecki, J.; Bajdak-Rusinek, K.; Kupnicka, P.; Kapczuk, P.; Simińska, D.; Chlubek, D.; Baranowska-Bosiacka, I. The Role of CXCL16 in the Pathogenesis of Cancer and Other Diseases. Int. J. Mol. Sci. 2021, 22, 3490. [CrossRef]

100. Decock, B.; Conings, R.; Lenaerts, J.-P.; Billiau, A.; Van Damme, J. Identification of the monocyte chemotactic protein from human osteosarcoma cells and monocytes: Detection of a novel N-terminally processed form. Biochem. Biophys. Res. Commun. 1990, 167, 904-909. [CrossRef]

101. Lu, Y.; Cai, Z.; Galson, D.L.; Xiao, G.; Liu, Y.; George, D.E.; Melhem, M.F.; Yao, Z.; Zhang, J. Monocyte chemotactic protein1 (MCP-1) acts as a paracrine and autocrine factor for prostate cancer growth and invasion. Prostate 2006, 66, 1311-1318. [CrossRef] [PubMed]

102. Zhang, J.; Patel, L.; Pienta, K.J. CC chemokine ligand 2 (CCL2) promotes prostate cancer tumorigenesis and metastasis. Cytokine Growth Factor Rev. 2010, 21, 41-48. [CrossRef] [PubMed]

103. Salcedo, R.; Ponce, M.L.; Young, H.A.; Wasserman, K.; Ward, J.M.; Kleinman, H.K.; Oppenheim, J.J.; Murphy, W.J. Human endothelial cells express CCR2 and respond to MCP-1: Direct role of MCP-1 in angiogenesis and tumor progression. Blood 2000, 96, 34-40. [CrossRef] [PubMed]

104. Mantovani, A.; Schioppa, T.; Porta, C.; Allavena, P.; Sica, A. Role of tumor-associated macrophages in tumor progression and invasion. Cancer Metastasis Rev. 2006, 25, 315-322. [CrossRef]

105. Lee, H.W.; Choi, H.J.; Ha, S.J.; Lee, K.T.; Kwon, Y.G. Recruitment of monocytes/macrophages in different tumor microenvironments. Biochim. Biophys. Acta. 2013, 1835, 170-179. [CrossRef] [PubMed]

106. Huang, B.; Lei, Z.; Zhao, J.; Gong, W.; Liu, J.; Chen, Z.; Liu, Y.; Li, D.; Yuan, Y.; Zhang, G.-M.; et al. CCL2/CCR2 pathway mediates recruitment of myeloid suppressor cells to cancers. Cancer Lett. 2007, 252, 86-92. [CrossRef] [PubMed]

107. Loberg, R.D.; Day, L.L.; Harwood, J.; Ying, C.; John, L.N.S.; Giles, R.; Neeley, C.K.; Pienta, K. CCL2 is a Potent Regulator of Prostate Cancer Cell Migration and Proliferation. Neoplasia 2006, 8, 578-586. [CrossRef] [PubMed]

108. Granot, Z.; Henke, E.; Comen, E.A.; King, T.A.; Norton, L.; Benezra, R. Tumor entrained neutrophils inhibit seeding in the premetastatic lung. Cancer Cell 2011, 20, 300-314. [CrossRef]

109. Molon, B.; Ugel, S.; Del Pozzo, F.; Soldani, C.; Zilio, S.; Avella, D.; De Palma, A.; Mauri, P.; Monegal, A.; Rescigno, M.; et al. Chemokine nitration prevents intratumoral infiltration of antigen-specific T cells. J. Exp. Med. 2011, 208, 1949-1962. [CrossRef] [PubMed]

110. Imai, T.; Nagira, M.; Takagi, S.; Kakizaki, M.; Nishimura, M.; Wang, J.; Gray, P.W.; Matsushima, K.; Yoshie, O. Selective recruitment of CCR4-bearing Th2 cells toward antigen-presenting cells by the CC chemokines thymus and activation-regulated chemokine and macrophage-derived chemokine. Int. Immunol. 1999, 11, 81-88. [CrossRef]

111. Ferenczi, K.; Fuhlbrigge, R.C.; Kupper, T.S.; Pinkus, J.L.; Pinkus, G.S. Increased CCR4 Expression in Cutaneous T Cell Lymphoma. J. Investig. Dermatol. 2002, 119, 1405-1410. [CrossRef]

112. Ishida, T.; Utsunomiya, A.; Iida, S.; Inagaki, H.; Takatsuka, Y.; Kusumoto, S.; Takeuchi, G.; Shimizu, S.; Ito, M.; Komatsu, H.; et al. Clinical significance of CCR4 expression in adult T-cell leukemia/lymphoma: Its close association with skin involvement and unfavorable outcome. Clin. Cancer Res. 2003, 9, 3625-3634.

113. Ogura, M.; Ishida, T.; Hatake, K.; Taniwaki, M.; Ando, K.; Tobinai, K.; Fujimoto, K.; Yamamoto, K.; Miyamoto, T.; Uike, N.; et al Multicenter Phase II Study of Mogamulizumab (KW-0761), a Defucosylated Anti-CC Chemokine Receptor 4 Antibody, in Patients With Relapsed Peripheral T-Cell Lymphoma and Cutaneous T-Cell Lymphoma. J. Clin. Oncol. 2014, 32, 1157-1163. [CrossRef] 
114. Ishida, T.; Joh, T.; Uike, N.; Yamamoto, K.; Utsunomiya, A.; Yoshida, S.; Saburi, Y.; Miyamoto, T.; Takemoto, S.; Suzushima, H.; et al. Defucosylated Anti-CCR4 Monoclonal Antibody (KW-0761) for Relapsed Adult T-Cell Leukemia-Lymphoma: A Multicenter Phase II Study. J. Clin. Oncol. 2012, 30, 837-842. [CrossRef]

115. Korbecki, J.; Kojder, K.; Simińska, D.; Bohatyrewicz, R.; Gutowska, I.; Chlubek, D.; Baranowska-Bosiacka, I. CC Chemokines in a Tumor: A Review of Pro-Cancer and Anti-Cancer Properties of the Ligands of Receptors CCR1, CCR2, CCR3, and CCR4. Int. J. Mol. Sci. 2020, 21, 8412. [CrossRef] [PubMed]

116. Olkhanud, P.B.; Baatar, D.; Bodogai, M.; Hakim, F.; Gress, R.; Anderson, R.; Deng, J.; Xu, M.; Briest, S.; Biragyn, A. Breast Cancer Lung Metastasis Requires Expression of Chemokine Receptor CCR4 and Regulatory T Cells. Cancer Res. 2009, 69, 5996-6004. [CrossRef]

117. Petersen, R.P.; Campa, M.J.; Sperlazza, J.; Conlon, D.; Joshi, M.-B.; Harpole, D.H.; Patz, E.F. Tumor infiltrating Foxp3+ regulatory T-cells are associated with recurrence in pathologic stage I NSCLC patients. Cancer 2006, 107, 2866-2872. [CrossRef]

118. Bohling, S.D.; Allison, K.H. Immunosuppressive regulatory T cells are associated with aggressive breast cancer phenotypes: A potential therapeutic target. Mod. Pathol. 2008, 21, 1527-1532. [CrossRef] [PubMed]

119. Kobayashi, N.; Hiraoka, N.; Yamagami, W.; Ojima, H.; Kanai, Y.; Kosuge, T.; Nakajima, A.; Hirohashi, S. FOXP3+ Regulatory T Cells Affect the Development and Progression of Hepatocarcinogenesis. Clin. Cancer Res. 2007, 13, 902-911. [CrossRef] [PubMed]

120. Anz, D.; Rapp, M.; Eiber, S.; Koelzer, V.; Thaler, R.; Haubner, S.; Knott, M.; Nagel, S.; Golic, M.; Wiedemann, G.; et al. Suppression of Intratumoral CCL22 by Type I Interferon Inhibits Migration of Regulatory T Cells and Blocks Cancer Progression. Cancer Res. 2015, 75, 4483-4493. [CrossRef]

121. Gobert, M.; Treilleux, I.; Bendriss-Vermare, N.; Bachelot, T.; Goddard-Leon, S.; Arfi, V.; Biota, C.; Doffin, A.C.; Durand, I.; Olive, D.; et al. Regulatory T Cells Recruited through CCL22/CCR4 Are Selectively Activated in Lymphoid Infiltrates Surrounding Primary Breast Tumors and Lead to an Adverse Clinical Outcome. Cancer Res. 2009, 69, 2000-2009. [CrossRef] [PubMed]

122. Curiel, T.J.; Coukos, G.; Zou, L.; Alvarez, X.; Cheng, P.; Mottram, P.; Evdemon-Hogan, M.; Conejo-Garcia, J.; Zhang, L.; Burow, M.; et al. Specific recruitment of regulatory T cells in ovarian carcinoma fosters immune privilege and predicts reduced survival. Nat. Med. 2004, 10, 942-949. [CrossRef]

123. Ishida, T.; Ishii, T.; Inagaki, A.; Yano, H.; Komatsu, H.; Iida, S.; Inagaki, H.; Ueda, R. Specific Recruitment of CC Chemokine Receptor 4-Positive Regulatory T Cells in Hodgkin Lymphoma Fosters Immune Privilege. Cancer Res. 2006, 66, 5716-5722. [CrossRef]

124. Mizukami, Y.; Kono, K.; Kawaguchi, Y.; Akaike, H.; Kamimura, K.; Sugai, H.; Fujii, H. CCL17 and CCL22 chemokines within tumor microenvironment are related to accumulation of Foxp3+ regulatory T cells in gastric cancer. Int. J. Cancer 2008, 122, 2286-2293. [CrossRef] [PubMed]

125. Dannull, J.; Su, Z.; Rizzieri, D.; Yang, B.K.; Coleman, D.; Yancey, D.; Zhang, A.; Dahm, P.; Chao, N.; Gilboa, E.; et al. Enhancement of vaccine-mediated antitumor immunity in cancer patients after depletion of regulatory T cells. J. Clin. Investig. 2005, 115, 3623-3633. [CrossRef] [PubMed]

126. Sutmuller, R.P.; Van Duivenvoorde, L.M.; Van Elsas, A.; Schumacher, T.; Wildenberg, M.E.; Allison, J.; Toes, R.; Offringa, R.; Melief, C.J. Synergism of Cytotoxic T Lymphocyte-Associated Antigen 4 Blockade and Depletion of Cd25+ Regulatory T Cells in Antitumor Therapy Reveals Alternative Pathways for Suppression of Autoreactive Cytotoxic T Lymphocyte Responses. J. Exp. Med. 2001, 194, 823-832. [CrossRef] [PubMed]

127. Thomas, J.K.; Mir, H.; Kapur, N.; Bae, S.; Singh, S. CC chemokines are differentially expressed in Breast Cancer and are associated with disparity in overall survival. Sci. Rep. 2019, 9, 1-12. [CrossRef] [PubMed]

128. Weide, B.; Allgaier, N.; Hector, A.; Forschner, A.; Leiter, U.; Eigentler, T.K.; Garbe, C.; Hartl, D. Increased CCL17 serum levels are associated with improved survival in advanced melanoma. Cancer Immunol. Immunother. 2015, 64, 1075-1082. [CrossRef] [PubMed]

129. Nakanishi, T.; Imaizumi, K.; Hasegawa, Y.; Kawabe, T.; Hashimoto, N.; Okamoto, M.; Shimokata, K. Expression of macrophagederived chemokine (MDC)/CCL22 in human lung cancer. Cancer Immunol. Immunother. 2006, 55, 1320-1329. [CrossRef]

130. Kimura, S.; Nanbu, U.; Noguchi, H.; Harada, Y.; Kumamoto, K.; Sasaguri, Y.; Nakayama, T. Macrophage CCL22 expression in the tumor microenvironment and implications for survival in patients with squamous cell carcinoma of the tongue. J. Oral Pathol. Med. 2019, 48, 677-685. [CrossRef] [PubMed]

131. Hua, F.; Tian, Y. CCL4 promotes the cell proliferation, invasion and migration of endometrial carcinoma by targeting the VEGF-A signal pathway. Int. J. Clin. Exp. Pathol. 2017, 10, 11288-11299.

132. Lien, M.-Y.; Tsai, H.-C.; Chang, A.-C.; Tsai, M.-H.; Hua, C.-H.; Wang, S.-W.; Tang, C.-H. Chemokine CCL4 Induces Vascular Endothelial Growth Factor C Expression and Lymphangiogenesis by miR-195-3p in Oral Squamous Cell Carcinoma. Front. Immunol. 2018, 9, 412. [CrossRef] [PubMed]

133. Bystry, R.S.; Aluvihare, V.R.; Welch, K.A.; Kallikourdis, M.; Betz, A.G. B cells and professional APCs recruit regulatory T cells via CCL4. Nat. Immunol. 2001, 2, 1126-1132. [CrossRef] [PubMed]

134. Schlecker, E.; Stojanovic, A.; Eisen, C.; Quack, C.; Falk, C.S.; Umansky, V.; Cerwenka, A.; Xu, M.; Hadinoto, V.; Appanna, R.; et al. Tumor-Infiltrating Monocytic Myeloid-Derived Suppressor Cells Mediate CCR5-Dependent Recruitment of Regulatory T Cells Favoring Tumor Growth. J. Immunol. 2012, 189, 5602-5611. [CrossRef] [PubMed]

135. Griss, J.; Bauer, W.; Wagner, C.; Simon, M.; Chen, M.; Grabmeier-Pfistershammer, K.; Maurer-Granofszky, M.; Roka, F.; Penz, T.; Bock, C.; et al. B cells sustain inflammation and predict response to immune checkpoint blockade in human melanoma. Nat. Commun. 2019, 10, 4186. [CrossRef] [PubMed] 
136. Gonzalez-Martin, A.; Gómez, L.; Lustgarten, J.; Mira, E.; Mañes, S.; Rechsteiner, M.P.; Von Teichman, A.; Nowicka, A.; Sulser, T.; Schraml, P.; et al. Maximal T Cell-Mediated Antitumor Responses Rely upon CCR5 Expression in Both CD4+ and CD8+ T Cells. Cancer Res. 2011, 71, 5455-5466. [CrossRef]

137. Zhao, N.; Dang, H.; Ma, L.; Martin, S.P.; Forgues, M.; Ylaya, K.; Hewitt, S.M.; Wang, X.W. Intratumoral $\gamma \delta$ T-Cell Infiltrates, Chemokine (C-C Motif) Ligand 4/Chemokine (C-C Motif) Ligand 5 Protein Expression and Survival in Patients With Hepatocellular Carcinoma. Hepatology 2021, 73, 1045-1060. [CrossRef] [PubMed]

138. Tan, M.C.; Goedegebuure, P.S.; Belt, B.A.; Flaherty, B.; Sankpal, N.; Gillanders, W.E.; Eberlein, T.J.; Hsieh, C.S.; Linehan, D.C. Disruption of CCR5-dependent homing of regulatory T cells inhibits tumor growth in a murine model of pancreatic cancer. $J$. Immunol. 2009, 182, 1746-1755. [CrossRef] [PubMed]

139. Tan, W.; Zhang, W.; Strasner, A.; Grivennikov, S.; Cheng, J.Q.; Hoffman, R.M.; Karin, M. Tumour-infiltrating regulatory T cells stimulate mammary cancer metastasis through RANKL-RANK signalling. Nature 2011, 470, 548-553. [CrossRef]

140. Velasco-Velázquez, M.; Pestell, R.G. The CCL5/CCR5 axis promotes metastasis in basal breast cancer. OncoImmunology 2013, 2, e23660. [CrossRef]

141. Azenshtein, E.; Luboshits, G.; Shina, S.; Neumark, E.; Shahbazian, D.; Weil, M.; Wigler, N.; Keydar, I.; Ben-Baruch, A. The CC chemokine RANTES in breast carcinoma progression: Regulation of expression and potential mechanisms of promalignant activity. Cancer Res. 2002, 62, 1093-1102.

142. Umansky, V.; Blattner, C.; Gebhardt, C.; Utikal, J. CCR5 in recruitment and activation of myeloid-derived suppressor cells in melanoma. Cancer Immunol. Immunother. 2017, 66, 1015-1023. [CrossRef]

143. Schutyser, E.; Struyf, S.; Van Damme, J. The CC chemokine CCL20 and its receptor CCR6. Cytokine Growth Factor Rev. 2003, 14, 409-426. [CrossRef]

144. Benkheil, M.; Van Haele, M.; Roskams, T.; Laporte, M.; Noppen, S.; Abbasi, K.; Delang, L.; Neyts, J.; Liekens, S. CCL20, a direct-acting pro-angiogenic chemokine induced by hepatitis $\mathrm{C}$ virus (HCV): Potential role in HCV-related liver cancer. Exp. Cell Res. 2018, 372, 168-177. [CrossRef]

145. Kadomoto, S.; Izumi, K.; Mizokami, A. The CCL20-CCR6 Axis in Cancer Progression. Int. J. Mol. Sci. 2020, 21, 5186. [CrossRef] [PubMed]

146. Zhang, C.-Y.; Qi, Y.; Li, X.-N.; Yang, Y.; Liu, D.-L.; Zhao, J.; Zhu, D.-Y.; Wu, K.; Zhou, X.-D.; Zhao, S. The role of CCL20/CCR6 axis in recruiting Treg cells to tumor sites of NSCLC patients. Biomed. Pharmacother. 2015, 69, 242-248. [CrossRef]

147. Nandi, B.; Shapiro, M.; Samur, M.K.; Pai, C.; Frank, N.Y.; Yoon, C.; Prabhala, R.H.; Munshi, N.C.; Gold, J.S. Stromal CCR6 drives tumor growth in a murine transplantable colon cancer through recruitment of tumor-promoting macrophages. OncoImmunology 2016, 5, e1189052. [CrossRef] [PubMed]

148. Walch-Rückheim, B.; Mavrova, R.; Henning, M.; Vicinus, B.; Kim, Y.-J.; Bohle, R.M.; Juhasz-Böss, I.; Solomayer, E.-F.; Smola, S. Stromal Fibroblasts Induce CCL20 through IL6/C/EBP $\beta$ to Support the Recruitment of Th17 Cells during Cervical Cancer Progression. Cancer Res. 2015, 75, 5248-5259. [CrossRef] [PubMed]

149. Bell, D.; Chomarat, P.; Broyles, D.; Netto, G.; Harb, G.M.; Lebecque, S.; Valladeau, J.; Davoust, J.; Palucka, K.A.; Banchereau, J. In breast carcinoma tissue, immature dendritic cells reside within the tumor, whereas mature dendritic cells are located in peritumoral areas. J. Exp. Med. 1999, 190, 1417-1426. [CrossRef]

150. Fushimi, T.; Kojima, A.; Moore, M.A.; Crystal, R.G. Macrophage inflammatory protein $3 \alpha$ transgene attracts dendritic cells to established murine tumors and suppresses tumor growth. J. Clin. Investig. 2000, 105, 1383-1393. [CrossRef]

151. Raman, D.; Baugher, P.J.; Thu, Y.M.; Richmond, A. Role of chemokines in tumor growth. Cancer Lett. 2007, 256, 137-165. [CrossRef] [PubMed]

152. Mburu, Y.K.; Wang, J.; Wood-Trageser, M.; Walker, W.H.; Ferris, R.L. CCR7 Mediates Inflammation-Associated Tumor Progression. Immunol. Res. 2006, 36, 61-72. [CrossRef]

153. Chen, J.; Yao, Y.; Gong, C.; Yu, F.; Su, S.; Chen, J.; Liu, B.; Deng, H.; Wang, F.; Lin, L.; et al. CCL18 from tumor-associated macrophages promotes breast cancer metastasis via PITPNM3. Cancer Cell 2011, 19, 541-555. [CrossRef] [PubMed]

154. Lin, L.; Chen, Y.-S.; Yao, Y.-D.; Chen, J.-Q.; Chen, J.-N.; Huang, S.-Y.; Zeng, Y.-J.; Yao, H.-R.; Zeng, S.-H.; Fu, Y.-S.; et al. CCL18 from tumor-associated macrophages promotes angiogenesis in breast cancer. Oncotarget 2015, 6, 34758-34773. [CrossRef] [PubMed]

155. Facciabene, A.; Peng, X.; Hagemann, I.S.; Balint, K.; Barchetti, A.; Wang, L.P.; Gimotty, P.A.; Gilks, C.B.; Lal, P.; Zhang, L.; et al. Tumour hypoxia promotes tolerance and angiogenesis via CCL28 and T(reg) cells. Nature 2011, 475, 226-230. [CrossRef]

156. Huang, G.; Tao, L.; Shen, S.; Chen, L. Hypoxia induced CCL28 promotes angiogenesis in lung adenocarcinoma by targeting CCR3 on endothelial cells. Sci. Rep. 2016, 6, 27152. [CrossRef]

157. Nakao, M.; Nomiyama, H.; Shimada, K. Structures of human genes coding for cytokine LD78 and their expression. Mol. Cell. Biol. 1990, 10, 3646-3658. [CrossRef]

158. Nibbs, R.; Yang, J.; Landau, N.R.; Mao, J.-H.; Graham, G. LD78 $\beta$, A Non-allelic Variant of Human MIP-1 $\alpha$ (LD78 $\alpha$ ), Has Enhanced Receptor Interactions and Potent HIV Suppressive Activity. J. Biol. Chem. 1999, 274, 17478-17483. [CrossRef]

159. Menten, P.; Struyf, S.; Schutyser, E.; Wuyts, A.; De Clercq, E.; Schols, D.; Proost, P.; Van Damme, J. The LD78beta isoform of MIP-1alpha is the most potent CCR5 agonist and HIV-1-inhibiting chemokine. J. Clin. Investig. 1999, 104, R1-R5. [CrossRef]

160. Yamamura, Y.; Hattori, T.; Obaru, K.; Sakai, K.; Asou, N.; Takatsuki, K.; Ohmoto, Y.; Nomiyama, H.; Shimada, K. Synthesis of a novel cytokine and its gene (LD78) expressions in hematopoietic fresh tumor cells and cell lines. J. Clin. Investig. 1989, 84, 1707-1712. [CrossRef] [PubMed] 
161. Jones, B.A.; Beamer, M.; Ahmed, S. Fractalkine/CX3CL1: A Potential New Target for Inflammatory Diseases. Mol. Interv. 2010, 10, 263-270. [CrossRef]

162. Imai, T.; Hieshima, K.; Haskell, C.; Baba, M.; Nagira, M.; Nishimura, M.; Kakizaki, M.; Takagi, S.; Nomiyama, H.; Schall, T.J.; et al. Identification and Molecular Characterization of Fractalkine Receptor CX3CR1, which Mediates Both Leukocyte Migration and Adhesion. Cell 1997, 91, 521-530. [CrossRef]

163. Robinson, L.A.; Nataraj, C.; Thomas, D.W.; Cosby, J.M.; Griffiths, R.; Bautch, V.L.; Patel, D.D.; Coffman, T.M. The chemokine CX3CL1 regulates NK cell activity in vivo. Cell Immunol. 2003, 225, 122-130. [CrossRef]

164. Lavergne, E.; Combadière, B.; Bonduelle, O.; Iga, M.; Gao, J.-L.; Maho, M.; Boissonnas, A.; Murphy, P.M.; Debré, P.; Combadière, C. Fractalkine mediates natural killer-dependent antitumor responses in vivo. Cancer Res. 2003, 63, 7468-7474. [PubMed]

165. Campbell, J.J.; Qin, S.; Unutmaz, D.; Soler, D.; Murphy, K.E.; Hodge, M.R.; Wu, L.; Butcher, E.C. Unique subpopulations of CD56+ NK and NK-T peripheral blood lymphocytes identified by chemokine receptor expression repertoire. J. Immunol. 2001, 166, 6477-6482. [CrossRef] [PubMed]

166. Inngjerdingen, M.; Damaj, B.; Maghazachi, A. Expression and regulation of chemokine receptors in human natural killer cells. Blood 2001, 97, 367-375. [CrossRef] [PubMed]

167. Shulby, S.A.; Dolloff, N.G.; Stearns, M.E.; Meucci, O.; Fatatis, A. CX3CR1-Fractalkine Expression Regulates Cellular Mechanisms Involved in Adhesion, Migration, and Survival of Human Prostate Cancer Cells. Cancer Res. 2004, 64, 4693-4698. [CrossRef]

168. Vanheule, V.; Metzemaekers, M.; Janssens, R.; Struyf, S.; Proost, P. How post-translational modifications influence the biological activity of chemokines. Cytokine 2018, 109, 29-51. [CrossRef]

169. Proost, P.; Struyf, S.; Van Damme, J.; Fiten, P.; Ugarte-Berzal, E.; Opdenakker, G. Chemokine isoforms and processing in inflammation and immunity. J. Autoimmun. 2017, 85, 45-57. [CrossRef]

170. Lambeir, A.-M.; Durinx, C.; Scharpé, S.; De Meester, I. Dipeptidyl-Peptidase IV from Bench to Bedside: An Update on Structural Properties, Functions, and Clinical Aspects of the Enzyme DPP IV. Crit. Rev. Clin. Lab. Sci. 2003, 40, 209-294. [CrossRef]

171. Bollaerta, Á.M.; Durinxb, C.; Goossensb, F.; Haemersa, A. The unique properties of dipeptidyl-peptidase IV (DPP IV / CD26) and the therapeutic potential of DPP IV inhibitors. Curr. Med. Chem. 1999, 6, 311-327.

172. Ishii, T.; Ohnuma, K.; Murakami, A.; Takasawa, N.; Kobayashi, S.; Dang, N.H.; Schlossman, S.F.; Morimoto, C. CD26-mediated signaling for T cell activation occurs in lipid rafts through its association with CD45RO. Proc. Natl. Acad. Sci. USA 2001, 98, 12138-12143. [CrossRef] [PubMed]

173. Durinx, C.; Lambeir, A.M.; Bosmans, E.; Falmagne, J.B.; Berghmans, R.; Haemers, A.; Scharpé, S.; De Meester, I. Molecular characterization of dipeptidyl peptidase activity in serum: Soluble CD26/dipeptidyl peptidase IV is responsible for the release of X-Pro dipeptides. Eur. J. Biochem. 2000, 267, 5608-5613. [CrossRef]

174. Raj, V.S.; Mou, H.; Smits, S.L.; Dekkers, D.H.W.; Müller, M.A.; Dijkman, R.; Muth, D.; Demmers, J.A.A.; Zaki, A.; Fouchier, R.A.M.; et al. Dipeptidyl peptidase 4 is a functional receptor for the emerging human coronavirus-EMC. Nature 2013, 495, 251-254. [CrossRef] [PubMed]

175. Klemann, C.; Wagner, L.; Stephan, M.; von Hörsten, S. Cut to the chase: A review of CD26/dipeptidyl peptidase-4's (DPP4) entanglement in the immune system. Clin. Exp. Immunol. 2016, 185, 1-21. [CrossRef] [PubMed]

176. Ou, X.; O'Leary, H.; Broxmeyer, H.E. Implications of DPP4 modification of proteins that regulate stem/progenitor and more mature cell types. Blood 2013, 122, 161-169. [CrossRef]

177. Glorie, L.; D’Haese, P.C.; Verhulst, A. Boning up on DPP4, DPP4 substrates, and DPP4-adipokine interactions: Logical reasoning and known facts about bone related effects of DPP4 inhibitors. Bone 2016, 92, 37-49. [CrossRef]

178. Kawakita, E.; Koya, D.; Kanasaki, K. CD26/DPP-4: Type 2 Diabetes Drug Target with Potential Influence on Cancer Biology. Cancers 2021, 13, 2191. [CrossRef]

179. Carl-McGrath, S.; Lendeckel, U.; Ebert, M.; Röcken, C. Ectopeptidases in tumour biology: A review. Histol. Histopathol. 2006, 21, 1339-1353.

180. Aratake, Y.; Kotani, T.; Tamura, K.; Araki, Y.; Kuribayashi, T.; Konoe, K.; Ohtaki, S. Dipeptidyl Aminopeptidase IV Staining of Cytologic Preparations to Distinguish Benign from Malignant Thyroid Diseases. Am. J. Clin. Pathol. 1991, 96, 306-310. [CrossRef]

181. Zheng, B.; Liu, J.; Gu, J.; Lu, Y.; Zhang, W.; Li, M.; Lu, H. A three-gene panel that distinguishes benign from malignant thyroid nodules. Int. J. Cancer 2014, 136, 1646-1654. [CrossRef]

182. Goscinski, M.A.; Suo, Z.H.; Nesland, J.M.; Flørenes, V.A.; Giercksky, K.-E. Dipeptidyl peptidase IV expression in cancer and stromal cells of human esophageal squamous cell carcinomas, adenocarcinomas and squamous cell carcinoma cell lines. APMIS 2008, 116, 823-831. [CrossRef] [PubMed]

183. Carbone, A.; Gloghini, A.; Zagonel, V.; Aldinucci, D.; Gattei, V.; Degan, M.; Improta, S.; Sorio, R.; Monfardini, S.; Pinto, A. The expression of CD26 and CD40 ligand is mutually exclusive in human T-cell non-Hodgkin's lymphomas/leukemias. Blood 1995, 86, 4617-4626. [CrossRef] [PubMed]

184. Inamoto, T.; Yamada, T.; Ohnuma, K.; Kina, S.; Takahashi, N.; Yamochi, T.; Inamoto, S.; Katsuoka, Y.; Hosono, O.; Tanaka, H.; et al. Humanized Anti-CD26 Monoclonal Antibody as a Treatment for Malignant Mesothelioma Tumors. Clin. Cancer Res. 2007, 13, 4191-4200. [CrossRef]

185. Asada, Y.; Aratake, Y.; Kotani, T.; Marutsuka, K.; Araki, Y.; Ohtaki, S.; Sumiyoshi, A. Expression of dipeptidyl aminopeptidase IV activity in human lung carcinoma. Histopathology 1993, 23, 265-270. [CrossRef] 
186. Pang, R.; Law, W.L.; Chu, A.C.; Poon, J.T.; Lam, C.S.; Chow, A.K.; Ng, L.; Cheung, L.W.; Lan, X.R.; Lan, H.Y.; et al. A Subpopulation of CD26+ Cancer Stem Cells with Metastatic Capacity in Human Colorectal Cancer. Cell Stem Cell 2010, 6, 603-615. [CrossRef] [PubMed]

187. Lam, C.S.-C.; Cheung, A.H.-K.; Wong, S.K.-M.; Wan, T.M.-H.; Ng, L.; Chow, A.K.-M.; Cheng, N.S.-M.; Pak, R.C.-H.; Li, H.-S.; Man, J.H.-W.; et al. Prognostic Significance of CD26 in Patients with Colorectal Cancer. PLoS ONE 2014, 9, e98582. [CrossRef] [PubMed]

188. Lee, J.J.; Wang, T.Y.; Liu, C.L.; Chien, M.N.; Chen, M.J.; Hsu, Y.C.; Leung, C.H.; Cheng, S.P. Dipeptidyl Peptidase IV as a Prognostic Marker and Therapeutic Target in Papillary Thyroid Carcinoma. J. Clin. Endocrinol. Metab. 2017, 102, 2930-2940. [CrossRef] [PubMed]

189. Bishnoi, R.; Hong, Y.; Shah, C.; Ali, A.; Iv, W.P.S.; Huo, J.; Dang, N.H.; Dang, L.H. Dipeptidyl peptidase 4 inhibitors as novel agents in improving survival in diabetic patients with colorectal cancer and lung cancer: A Surveillance Epidemiology and Endpoint Research Medicare study. Cancer Med. 2019, 8, 3918-3927. [CrossRef]

190. Bogenrieder, T.; Finstad, C.L.; Freeman, R.H.; Papandreou, C.N.; Scher, H.I.; Albino, A.P.; Reuter, V.E.; Nanus, D.M. Expression and localization of aminopeptidase $\mathrm{A}$, aminopeptidase $\mathrm{N}$, and dipeptidyl peptidase IV in benign and malignant human prostate tissue. Prostate 1997, 33, 225-232. [CrossRef]

191. Sakamoto, J.; Watanabe, T.; Teramukai, S.; Akiyama, S.; Morimoto, T.; Takaci, H.; Nakazato, H.; Ueda, R.; Takahashi, T. Distribution of adenosine deaminase binding protein in normal and malignant tissues of the gastrointestinal tract studied by monoclonal antibodies. J. Surg. Oncol. 1993, 52, 124-134. [CrossRef] [PubMed]

192. E Morrison, M.; Vijayasaradhi, S.; Engelstein, D.; Albino, A.P.; Houghton, A.N. A marker for neoplastic progression of human melanocytes is a cell surface ectopeptidase. J. Exp. Med. 1993, 177, 1135-1143. [CrossRef]

193. Khin, E.E.; Kikkawa, F.; Ino, K.; Kajiyama, H.; Suzuki, T.; Shibata, K.; Tamakoshi, K.; Nagasaka, T.; Mizutani, S. Dipeptidyl peptidase IV expression in endometrial endometrioid adenocarcinoma and its inverse correlation with tumor grade. Am. J. Obstet. Gynecol. 2003, 188, 670-676. [CrossRef]

194. Wesley, U.V.; McGroarty, M.; Homoyouni, A.; Ilsley, J.N.; Nakanishi, M.; Flynn, C.; Belinsky, G.S.; De Guise, S.; Adib, J.N.; Dobrowsky, R.T.; et al. Dipeptidyl Peptidase Inhibits Malignant Phenotype of Prostate Cancer Cells by Blocking Basic Fibroblast Growth Factor Signaling Pathway. Cancer Res. 2005, 65, 1325-1334. [CrossRef] [PubMed]

195. Wesley, U.V.; Tiwari, S.; Houghton, A.N. Role for dipeptidyl peptidase IV in tumor suppression of human non small cell lung carcinoma cells. Int. J. Cancer 2004, 109, 855-866. [CrossRef] [PubMed]

196. Mezawa, Y.; Daigo, Y.; Takano, A.; Miyagi, Y.; Yokose, T.; Yamashita, T.; Morimoto, C.; Hino, O.; Orimo, A. CD26 expression is attenuated by TGF- $\beta$ and SDF-1 autocrine signaling on stromal myofibroblasts in human breast cancers. Cancer Med. 2019, 8 , 3936-3948. [CrossRef] [PubMed]

197. Busek, P.; Stremenova, J.; Sromova, L.; Hilser, M.; Balaziova, E.; Kosek, D.; Trylcova, J.; Strnad, H.; Krepela, E.; Sedo, A. Dipeptidyl peptidase-IV inhibits glioma cell growth independent of its enzymatic activity. Int. J. Biochem. Cell Biol. 2012, 44, 738-747. [CrossRef] [PubMed]

198. Wesley, U.V.; Albino, A.P.; Tiwari, S.; Houghton, A.N. A Role for Dipeptidyl Peptidase IV in Suppressing the Malignant Phenotype of Melanocytic Cells. J. Exp. Med. 1999, 190, 311-322. [CrossRef]

199. Wuyts, A.; Govaerts, C.; Struyf, S.; Lenaerts, J.P.; Put, W.; Conings, R.; Proost, P.; Van Damme, J. Isolation of the CXC chemokines ENA-78, GRO alpha and GRO gamma from tumor cells and leukocytes reveals $\mathrm{NH}_{2}$-terminal heterogeneity. Functional comparison of different natural isoforms. Eur. J. Biochem. 1999, 260, 421-429. [CrossRef]

200. Proost, P.; Struyf, S.; Couvreur, M.; Lenaerts, J.P.; Conings, R.; Menten, P.; Verhaert, P.; Wuyts, A.; Van Damme, J. Posttranslational modifications affect the activity of the human monocyte chemotactic proteins MCP-1 and MCP-2: Identification of MCP-2(6-76) as a natural chemokine inhibitor. J. Immunol. 1998, 160, 4034-4041. [PubMed]

201. Van Damme, J.; Proost, P.; Lenaerts, J.P.; Opdenakker, G. Structural and functional identification of two human, tumor-derived monocyte chemotactic proteins (MCP-2 and MCP-3) belonging to the chemokine family. J. Exp. Med. 1992, 176, 59-65. [CrossRef] [PubMed]

202. Struyf, S.; Proost, P.; Vandercappellen, J.; Dempe, S.; Noyens, B.; Nelissen, S.; Gouwy, M.; Locati, M.; Opdenakker, G.; Dinsart, C.; et al. Synergistic up-regulation of MCP-2/CCL8 activity is counteracted by chemokine cleavage, limiting its inflammatory and anti-tumoral effects. Eur. J. Immunol. 2009, 39, 843-857. [CrossRef] [PubMed]

203. Proost, P.; De Meester, I.; Schols, D.; Struyf, S.; Lambeir, A.M.; Wuyts, A.; Opdenakker, G.; De Clercq, E.; Scharpé, S.; Van Damme, J. Amino-terminal truncation of chemokines by CD26/dipeptidyl-peptidase IV. Conversion of RANTES into a potent inhibitor of monocyte chemotaxis and HIV-1-infection. J. Biol. Chem. 1998, 273, 7222-7227. [CrossRef] [PubMed]

204. Qin, C.-J.; Zhao, L.-H.; Zhou, X.; Zhang, H.-L.; Wen, W.; Tang, L.; Zeng, M.; Wang, M.-D.; Fu, G.-B.; Huang, S.; et al. Inhibition of dipeptidyl peptidase IV prevents high fat diet-induced liver cancer angiogenesis by downregulating chemokine ligand 2 . Cancer Lett. 2018, 420, 26-37. [CrossRef] [PubMed]

205. Ajami, K.; Pitman, M.R.; Wilson, C.H.; Park, J.; Menz, R.I.; Starr, A.E.; Cox, J.H.; Abbott, C.A.; Overall, C.M.; Gorrell, M.D Stromal cell-derived factors 1alpha and 1beta, inflammatory protein-10 and interferon-inducible T cell chemo-attractant are novel substrates of dipeptidyl peptidase 8. FEBS Lett. 2008, 582, 819-825. [CrossRef] [PubMed]

206. Roodman, G.D. Regulation of osteoclast differentiation. Ann. N. Y. Acad. Sci. 2006, 1068, 100-109. [CrossRef]

207. King, A.G.; Johanson, K.; Frey, C.L.; DeMarsh, P.L.; White, J.R.; McDevitt, P.; McNulty, D.; Balcarek, J.; Jonak, Z.L.; Bhatnagar, P.K.; et al. Identification of unique truncated $\mathrm{KC} / \mathrm{GRO}$ beta chemokines with potent hematopoietic and anti-infective activities. J. Immunol. 2000, 164, 3774-3782. [CrossRef] 
208. Tan, C.W.; Lee, Y.H.; Tan, H.H.; Lau, M.S.K.; Choolani, M.; Griffith, L.; Chan, J.K.Y. CD26/DPPIV down-regulation in endometrial stromal cell migration in endometriosis. Fertil. Steril. 2014, 102, 167-177.e9. [CrossRef]

209. Guan, E.; Wang, J.; Norcross, M.A. Amino-terminal processing of MIP-1beta/CCL4 by CD26/dipeptidyl-peptidase IV. J. Cell. Biochem. 2004, 92, 53-64. [CrossRef]

210. Guan, E.; Wang, J.; Roderiquez, G.; Norcross, M.A.; Li, D.; Zimmerman, T.L.; Thevananther, S.; Lee, H.-Y.; Kurie, J.M.; Karpen, S.J. Natural Truncation of the Chemokine MIP-1 $\beta$ /CCL4 Affects Receptor Specificity but Not Anti-HIV-1 Activity. J. Biol. Chem. 2002, 277, 32348-32352. [CrossRef]

211. Broxmeyer, H.E.; Capitano, M.; Campbell, T.B.; Hangoc, G.; Cooper, S. Modulation of Hematopoietic Chemokine Effects In Vitro and In Vivo by DPP-4/CD26. Stem Cells Dev. 2016, 25, 575-585. [CrossRef] [PubMed]

212. Townson, J.R.; Barcellos, L.F.; Nibbs, R.J.B. Gene copy number regulates the production of the human chemokine CCL3-L1. Eur. J. Immunol. 2002, 32, 3016-3026. [CrossRef]

213. E Broxmeyer, H.; Hoggatt, J.; O’Leary, H.; Mantel, C.; Chitteti, B.R.; Cooper, S.; Messina-Graham, S.; Hangoc, G.; Farag, S.; Rohrabaugh, S.L.; et al. Dipeptidylpeptidase 4 negatively regulates colony-stimulating factor activity and stress hematopoiesis. Nat. Med. 2012, 18, 1786-1796. [CrossRef] [PubMed]

214. Farag, S.S.; Srivastava, S.; Messina-Graham, S.; Schwartz, J.; Robertson, M.J.; Abonour, R.; Cornetta, K.; Wood, L.; Secrest, A.; Strother, R.M.; et al. In Vivo DPP-4 Inhibition to Enhance Engraftment of Single-Unit Cord Blood Transplants in Adults with Hematological Malignancies. Stem Cells Dev. 2013, 22, 1007-1015. [CrossRef]

215. Oravecz, T.; Pall, M.; Roderiquez, G.; Gorrell, M.; Ditto, M.; Nguyen, N.Y.; Boykins, R.; Unsworth, E.; Norcross, M.A. Regulation of the Receptor Specificity and Function of the Chemokine RANTES (Regulated on Activation, Normal T Cell Expressed and Secreted) by Dipeptidyl Peptidase IV (CD26)-mediated Cleavage. J. Exp. Med. 1997, 186, 1865-1872. [CrossRef] [PubMed]

216. Iwata, S.; Yamaguchi, N.; Munakata, Y.; Ikushima, H.; Lee, J.F.; Hosono, O.; Schlossman, S.F.; Morimoto, C. CD26/dipeptidyl peptidase IV differentially regulates the chemotaxis of T cells and monocytes toward RANTES: Possible mechanism for the switch from innate to acquired immune response. Int. Immunol. 1999, 11, 417-426. [CrossRef]

217. Struyf, S.; De Meester, I.; Scharpé, S.; Lenaerts, J.-P.; Menten, P.; Wang, J.M.; Proost, P.; Van Damme, J. Natural truncation of RANTES abolishes signaling through the CC chemokine receptors CCR1 and CCR3, impairs its chemotactic potency and generates a CC chemokine inhibitor. Eur. J. Immunol. 1998, 28, 1262-1271. [CrossRef]

218. Favre-Kontula, L.; Johnson, Z.; Steinhoff, T.; Frauenschuh, A.; Vilbois, F.; Proudfoot, A.E. Quantitative detection of therapeutic proteins and their metabolites in serum using antibody-coupled ProteinChip ${ }^{\circledR}$ Arrays and SELDI-TOF-MS. J. Immunol. Methods 2006, 317, 152-162. [CrossRef]

219. Proost, P.; Menten, P.; Struyf, S.; Schutyser, E.; De Meester, I.; Van Damme, J. Cleavage by CD26/dipeptidyl peptidase IV converts the chemokine LD78beta into a most efficient monocyte attractant and CCR1 agonist. Blood 2000, 96, 1674-1680. [CrossRef]

220. Struyf, S.; Menten, P.; Lenaerts, J.P.; Put, W.; D’Haese, A.; De Clercq, E.; Schols, D.; Proost, P.; Van Damme, J. Diverging binding capacities of natural LD78beta isoforms of macrophage inflammatory protein-1alpha to the CC chemokine receptors 1, 3 and 5 affect their anti-HIV-1 activity and chemotactic potencies for neutrophils and eosinophils. Eur. J. Immunol. 2001, 31, 2170-2178. [CrossRef]

221. Lambeir, A.-M.; Proost, P.; Durinx, C.; Bal, G.; Senten, K.; Augustyns, K.; Scharpé, S.; Van Damme, J.; De Meester, I. Kinetic Investigation of Chemokine Truncation by CD26/Dipeptidyl Peptidase IV Reveals a Striking Selectivity within the Chemokine Family. J. Biol. Chem. 2001, 276, 29839-29845. [CrossRef]

222. Proost, P.; Schutyser, E.; Menten, P.; Struyf, S.; Wuyts, A.; Opdenakker, G.; Detheux, M.; Parmentier, M.; Durinx, C.; Lambeir, A.-M.; et al. Amino-terminal truncation of CXCR3 agonists impairs receptor signaling and lymphocyte chemotaxis, while preserving antiangiogenic properties. Blood 2001, 98, 3554-3561. [CrossRef] [PubMed]

223. Ludwig, A.; Schiemann, F.; Mentlein, R.; Lindner, B.; Brandt, E. Dipeptidyl peptidase IV (CD26) on T cells cleaves the CXC chemokine CXCL11 (I-TAC) and abolishes the stimulating but not the desensitizing potential of the chemokine. J. Leukoc. Biol. 2002, 72, 183-191.

224. Chevigné, A.; Janji, B.; Meyrath, M.; Reynders, N.; D’Uonnolo, G.; Uchański, T.; Xiao, M.; Berchem, G.; Ollert, M.; Kwon, Y.-J.; et al. CXCL10 Is an Agonist of the CC Family Chemokine Scavenger Receptor ACKR2/D6. Cancers 2021, 13, 1054. [CrossRef] [PubMed]

225. Proost, P.; Mortier, A.; Loos, T.; Vandercappellen, J.; Gouwy, M.; Ronsse, I.; Schutyser, E.; Put, W.; Parmentier, M.; Struyf, S.; et al. Proteolytic processing of CXCL11 by CD13/aminopeptidase N impairs CXCR3 and CXCR7 binding and signaling and reduces lymphocyte and endothelial cell migration. Blood 2007, 110, 37-44. [CrossRef] [PubMed]

226. Burns, J.M.; Summers, B.C.; Wang, Y.; Melikian, A.; Berahovich, R.; Miao, Z.; Penfold, M.E.T.; Sunshine, M.J.; Littman, D.R.; Kuo, C.J.; et al. A novel chemokine receptor for SDF-1 and I-TAC involved in cell survival, cell adhesion, and tumor development. J. Exp. Med. 2006, 203, 2201-2213. [CrossRef]

227. Cook, S.J.; Lee, Q.; Wong, A.C.H.; Spann, B.C.; Vincent, J.N.; Wong, J.J.L.; Schlitzer, A.; Gorrell, M.D.; Weninger, W.; Roediger, B. Differential chemokine receptor expression and usage by pre-cDC1 and pre-cDC2. Immunol. Cell Biol. 2018, 96, 1131-1139. [CrossRef] [PubMed]

228. Nishina, S.; Yamauchi, A.; Kawaguchi, T.; Kaku, K.; Goto, M.; Sasaki, K.; Hara, Y.; Tomiyama, Y.; Kuribayashi, F.; Torimura, T.; et al. Dipeptidyl Peptidase 4 Inhibitors Reduce Hepatocellular Carcinoma by Activating Lymphocyte Chemotaxis in Mice. Cell. Mol. Gastroenterol. Hepatol. 2019, 7, 115-134. [CrossRef] [PubMed] 
229. Wolf, M.; Albrecht, S.; Marki, C. Proteolytic processing of chemokines: Implications in physiological and pathological conditions. Int. J. Biochem. Cell Biol. 2008, 40, 1185-1198. [CrossRef]

230. Barreira da Silva, R.; Laird, M.E.; Yatim, N.; Fiette, L.; Ingersoll, M.A.; Albert, M.L. Dipeptidylpeptidase 4 inhibition enhances lymphocyte trafficking, improving both naturally occurring tumor immunity and immunotherapy. Nat. Immunol. 2015, 16, 850-858. [CrossRef]

231. Bailey, S.R.; Nelson, M.H.; Majchrzak-Kuligowska, K.; Bowers, J.; Wyatt, M.M.; Smith, A.S.; Neal, L.R.; Shirai, K.; Carpenito, C.; June, C.H.; et al. Human CD26 $6^{\text {high }} \mathrm{T}$ cells elicit tumor immunity against multiple malignancies via enhanced migration and persistence. Nat. Commun. 2017, 8, 1-13. [CrossRef] [PubMed]

232. Decalf, J.; Tarbell, K.V.; Casrouge, A.; Price, J.D.; Linder, G.; Mottez, E.; Sultanik, P.; Mallet, V.; Pol, S.; Duffy, D.; et al. Inhibition of DPP4 activity in humans establishes its in vivo role in CXCL10 post-translational modification: Prospective placebo-controlled clinical studies. EMBO Mol. Med. 2016, 8, 679-683. [CrossRef]

233. Casrouge, A.; Bisiaux, A.; Stephen, L.; Schmolz, M.; Mapes, J.; Pfister, C.; Pol, S.; Mallet, V.; Albert, M.L. Discrimination of agonist and antagonist forms of CXCL10 in biological samples. Clin. Exp. Immunol. 2011, 167, 137-148. [CrossRef]

234. Rainczuk, A.; Rao, J.R.; Gathercole, J.; Fairweather, N.J.; Chu, S.; Masadah, R.; Jobling, T.W.; Deb-Choudhury, S.; Dyer, J.; Stephens, A.N. Evidence for the antagonistic form of CXC-motif chemokine CXCL10 in serous epithelial ovarian tumours. Int. J. Cancer 2013, 134, 530-541. [CrossRef]

235. Struyf, S.; Proost, P.; Schols, D.; De Clercq, E.; Opdenakker, G.; Lenaerts, J.P.; Detheux, M.; Parmentier, M.; De Meester, I.; Scharpé, S.; et al. CD26/dipeptidyl-peptidase IV down-regulates the eosinophil chemotactic potency, but not the anti-HIV activity of human eotaxin by affecting its interaction with CC chemokine receptor 3. J. Immunol. 1999, 162, 4903-4909. [PubMed]

236. Dorta, R.G.; Landman, G.; Kowalski, L.P.; Lauris, J.; Latorre, M.R.D.O.; Oliveira, D.T. Tumour-associated tissue eosinophilia as a prognostic factor in oral squamous cell carcinomas. Histopathology 2002, 41, 152-157. [CrossRef] [PubMed]

237. Fernández-Aceñero, M.J.; Galindo-Gallego, M.; Sanz, J.; Aljama, A. Prognostic influence of tumor-associated eosinophilic infiltrate in colorectal carcinoma. Cancer 2000, 88, 1544-1548. [CrossRef]

238. Reichman, H.; Karo-Atar, D.; Munitz, A. Emerging Roles for Eosinophils in the Tumor Microenvironment. Trends Cancer 2016, 2, 664-675. [CrossRef]

239. Hollande, C.; Boussier, J.; Ziai, J.; Nozawa, T.; Bondet, V.; Phung, W.; Lu, B.; Duffy, D.; Paradis, V.; Mallet, V.; et al. Inhibition of the dipeptidyl peptidase DPP4 (CD26) reveals IL-33-dependent eosinophil-mediated control of tumor growth. Nat. Immunol. 2019, 20, 257-264. [CrossRef]

240. Miyagaki, T.; Sugaya, M.; Fujita, H.; Ohmatsu, H.; Kakinuma, T.; Kadono, T.; Tamaki, K.; Sato, S. Eotaxins and CCR3 Interaction Regulates the Th2 Environment of Cutaneous T-Cell Lymphoma. J. Investig. Dermatol. 2010, 130, 2304-2311. [CrossRef]

241. Struyf, S.; Proost, P.; Sozzani, S.; Mantovani, A.; Wuyts, A.; De Clercq, E.; Schols, D.; Van Damme, J. Enhanced anti-HIV-1 activity and altered chemotactic potency of $\mathrm{NH}_{2}$-terminally processed macrophage-derived chemokine (MDC) imply an additional MDC receptor. J. Immunol. 1998, 161, 2672-2675. [PubMed]

242. Proost, P.; Struyf, S.; Schols, D.; Opdenakker, G.; Sozzani, S.; Allavena, P.; Mantovani, A.; Augustyns, K.; Bal, G.; Haemers, A.; et al. Truncation of macrophage-derived chemokine by CD26/ dipeptidyl-peptidase IV beyond its predicted cleavage site affects chemotactic activity and CC chemokine receptor 4 interaction. J. Biol. Chem. 1999, 274, 3988-3993. [CrossRef] [PubMed]

243. Bonecchi, R.; Locati, M.; Galliera, E.; Vulcano, M.; Sironi, M.; Fra, A.M.; Gobbi, M.; Vecchi, A.; Sozzani, S.; Haribabu, B.; et al Differential Recognition and Scavenging of Native and Truncated Macrophage-Derived Chemokine (Macrophage-Derived Chemokine/CC Chemokine Ligand 22) by the D6 Decoy Receptor. J. Immunol. 2004, 172, 4972-4976. [CrossRef] [PubMed]

244. Fierro, M.T.; Comessatti, A.; Quaglino, P.; Ortoncelli, M.; Abate, S.O.; Ponti, R.; Novelli, M.; Bernengo, M.G. Expression Pattern of Chemokine Receptors and Chemokine Release in Inflammatory Erythroderma and Sézary Syndrome. Dermatology 2006, 213, 284-292. [CrossRef]

245. Kagdi, H.H.; Demontis, M.A.; Fields, P.A.; Ramos, J.C.; Bangham, C.R.M.; Taylor, G.P. Risk stratification of adult T-cell leukemia/lymphoma using immunophenotyping. Cancer Med. 2017, 6, 298-309. [CrossRef]

246. Richardson, S.K.; Newton, S.B.; Bach, T.L.; Budgin, J.B.; Benoit, B.M.; Lin, J.H.; Yoon, J.S.; Wysocka, M.; Abrams, C.S.; Rook, A.H Bexarotene blunts malignant T-cell chemotaxis in Sezary syndrome: Reduction of chemokine receptor 4-positive lymphocytes and decreased chemotaxis to thymus and activation-regulated chemokine. Am. J. Hematol. 2007, 82, 792-797. [CrossRef] [PubMed]

247. Shioda, T.; Kato, H.; Ohnishi, Y.; Tashiro, K.; Ikegawa, M.; Nakayama, E.E.; Hu, H.; Kato, A.; Sakai, Y.; Liu, H.; et al. AntiHIV-1 and chemotactic activities of human stromal cell-derived factor 1alpha (SDF-1alpha) and SDF-1beta are abolished by CD26/dipeptidyl peptidase IV-mediated cleavage. Proc. Natl. Acad. Sci. USA 1998, 95, 6331-6336. [CrossRef]

248. Proost, P.; Struyf, S.; Schols, D.; Durinx, C.; Wuyts, A.; Lenaerts, J.-P.; De Clercq, E.; De Meester, I.; Van Damme, J. Processing by CD26/dipeptidyl-peptidase IV reduces the chemotactic and anti-HIV-1 activity of stromal-cell-derived factor-1 $\alpha$. FEBS Lett. 1998, 432, 73-76. [CrossRef]

249. Ohtsuki, T.; Hosono, O.; Kobayashi, H.; Munakata, Y.; Souta, A.; Shioda, T.; Morimoto, C. Negative regulation of the anti-human immunodeficiency virus and chemotactic activity of human stromal cell-derived factor $1 \alpha$ by CD26/dipeptidyl peptidase IV. FEBS Lett. 1998, 431, 236-240. [CrossRef]

250. Janssens, R.; Mortier, A.; Boff, D.; Ruytinx, P.; Gouwy, M.; Vantilt, B.; Larsen, O.; Daugvilaite, V.; Rosenkilde, M.M.; Parmentier, M.; et al. Truncation of CXCL12 by CD26 reduces its CXC chemokine receptor 4- and atypical chemokine receptor 3-dependent activity on endothelial cells and lymphocytes. Biochem. Pharmacol. 2017, 132, 92-101. [CrossRef] 
251. Herrera, C.; Morimoto, C.; Blanco, J.; Mallol, J.; Arenzana, F.; Lluis, C.; Franco, R. Comodulation of CXCR4 and CD26 in Human Lymphocytes. J. Biol. Chem. 2001, 276, 19532-19539. [CrossRef] [PubMed]

252. Karpova, D.; Bonig, H. Concise Review: CXCR4/CXCL12 Signaling in Immature Hematopoiesis-Lessons From Pharmacological and Genetic Models. Stem Cells 2015, 33, 2391-2399. [CrossRef]

253. Nagasawa, T.; Kikutani, H.; Kishimoto, T. Molecular cloning and structure of a pre-B-cell growth-stimulating factor. Proc. Natl. Acad. Sci. USA 1994, 91, 2305-2309. [CrossRef]

254. Christopherson, K.W.; Hangoc, G.; Broxmeyer, H.E. Cell surface peptidase CD26/dipeptidylpeptidase IV regulates CXCL12/stromal cell-derived factor-1 alpha-mediated chemotaxis of human cord blood CD34+ progenitor cells. J. Immunol. 2002, 169, 7000-7008. [CrossRef]

255. Ruiz, P.; Zacharievich, N.; Viciana, A.L.; Shenkin, M. Peripheral CD34+ progenitor cells express CD26 and contain increased dipeptidyl peptidase IV activity. Acta Haematol. 1998, 100, 110-112. [CrossRef]

256. Giri, D.; Ropiquet, F.; Ittmann, M. Alterations in expression of basic fibroblast growth factor (FGF) 2 and its receptor FGFR-1 in human prostate cancer. Clin. Cancer Res. 1999, 5, 1063-1071.

257. Yang, F.; Takagaki, Y.; Yoshitomi, Y.; Ikeda, T.; Li, J.; Kitada, M.; Kumagai, A.; Kawakita, E.; Shi, S.; Kanasaki, K.; et al. Inhibition of Dipeptidyl Peptidase-4 Accelerates Epithelial-Mesenchymal Transition and Breast Cancer Metastasis via the CXCL12/CXCR4/mTOR Axis. Cancer Res. 2019, 79, 735-746. [CrossRef] [PubMed]

258. Sun, Y.X.; Pedersen, E.A.; Shiozawa, Y.; Havens, A.M.; Jung, Y.; Wang, J.; Pienta, K.J.; Taichman, R.S. CD26/dipeptidyl peptidase IV regulates prostate cancer metastasis by degrading SDF-1/CXCL12. Clin. Exp. Metastasis 2008, 25, 765-776. [CrossRef]

259. Mizokami, Y.; Kajiyama, H.; Shibata, K.; Ino, K.; Kikkawa, F.; Mizutani, S. Stromal cell-derived factor-1 $\alpha$-induced cell proliferation and its possible regulation by CD26/dipeptidyl peptidase IV in endometrial adenocarcinoma. Int. J. Cancer 2004, 110, 652-659. [CrossRef] [PubMed]

260. Arscott, W.T.; LaBauve, A.E.; May, V.; Wesley, U.V. Suppression of neuroblastoma growth by dipeptidyl peptidase IV: Relevance of chemokine regulation and caspase activation. Oncogene 2008, 28, 479-491. [CrossRef]

261. Jones, D.; Dang, N.H.; Duvic, M.; Washington, L.T.; Huh, Y.O. Absence of CD26 Expression Is a Useful Marker for Diagnosis of T-Cell Lymphoma in Peripheral Blood. Am. J. Clin. Pathol. 2001, 115, 885-892. [CrossRef] [PubMed]

262. Narducci, M.G.; Scala, E.; Bresin, A.; Caprini, E.; Picchio, M.C.; Remotti, D.; Ragone, G.; Nasorri, F.; Frontani, M.; Arcelli, D.; et al. Skin homing of Sézary cells involves SDF-1-CXCR4 signaling and down-regulation of CD26/dipeptidylpeptidase IV. Blood 2006, 107, 1108-1115. [CrossRef] [PubMed]

263. Papayannopoulou, T.; Scadden, D.T. Stem-cell ecology and stem cells in motion. Blood 2008, 111, 3923-3930. [CrossRef]

264. Cho, S.Y.; Xu, M.; Roboz, J.; Lu, M.; Mascarenhas, J.; Hoffman, R. The Effect of CXCL12 Processing on CD34+ Cell Migration in Myeloproliferative Neoplasms. Cancer Res. 2010, 70, 3402-3410. [CrossRef]

265. Cutler, M.J.; Lowthers, E.L.; Richard, C.L.; Hajducek, D.M.; Spagnuolo, P.A.; Blay, J. Chemotherapeutic agents attenuate CXCL12mediated migration of colon cancer cells by selecting for CXCR4-negative cells and increasing peptidase CD26. BMC Cancer 2015, 15, 882. [CrossRef]

266. Van Coillie, E.; Proost, P.; Van Aelst, L.; Struyf, S.; Polfliet, M.; De Meester, I.; Harvey, D.J.; Van Damme, A.J.; Opdenakker, G. Functional Comparison of Two Human Monocyte Chemotactic Protein-2 Isoforms, Role of the Amino-Terminal Pyroglutamic Acid and Processing by CD26/Dipeptidyl Peptidase IV. Biochemistry 1998, 37, 12672-12680. [CrossRef]

267. Salanga, C.; Handel, T. Chemokine oligomerization and interactions with receptors and glycosaminoglycans: The role of structural dynamics in function. Exp. Cell Res. 2011, 317, 590-601. [CrossRef]

268. Proudfoot, A.E.I.; Handel, T.M.; Johnson, Z.; Lau, E.K.; LiWang, P.; Clark-Lewis, I.; Borlat, F.; Wells, T.; Kosco-Vilbois, M.H. Glycosaminoglycan binding and oligomerization are essential for the in vivo activity of certain chemokines. Proc. Natl. Acad. Sci. USA 2003, 100, 1885-1890. [CrossRef]

269. Kim, K.-S.; Rajarathnam, K.; Clark-Lewis, I.; Sykes, B.D. Structural characterization of a monomeric chemokine: Monocyte chemoattractant protein-3. FEBS Lett. 1996, 395, 277-282. [CrossRef]

270. Veldkamp, C.T.; Peterson, F.C.; Pelzek, A.J.; Volkman, B.F. The monomer-dimer equilibrium of stromal cell-derived factor-1 (CXCL12) is altered by $\mathrm{pH}$, phosphate, sulfate, and heparin. Protein Sci. 2005, 14, 1071-1081. [CrossRef]

271. Ren, M.; Guo, Q.; Guo, L.; Lenz, M.; Qian, F.; Koenen, R.; Xu, H.; Schilling, A.B.; Weber, C.; Ye, R.D.; et al. Polymerization of MIP-1 chemokine (CCL3 and CCL4) and clearance of MIP-1 by insulin-degrading enzyme. EMBO J. 2010, 29, 3952-3966. [CrossRef]

272. Metzemaekers, M.; Mortier, A.; Janssens, R.; Boff, D.; Vanbrabant, L.; Lamoen, N.; Van Damme, J.; Teixeira, M.M.; De Meester, I.; Amaral, F.A.; et al. Glycosaminoglycans Regulate CXCR3 Ligands at Distinct Levels: Protection against Processing by Dipeptidyl Peptidase IV/CD26 and Interference with Receptor Signaling. Int. J. Mol. Sci. 2017, 18, 1513. [CrossRef]

273. Sadir, R.; Imberty, A.; Baleux, F.; Lortat-Jacob, H. Heparan sulfate/heparin oligosaccharides protect stromal cell-derived factor-1 (SDF-1)/CXCL12 against proteolysis induced by CD26/dipeptidyl peptidase IV. J. Biol. Chem. 2004, 279, 43854-43860. [CrossRef]

274. Mortier, A.; Gouwy, M.; Van Damme, J.; Proost, P.; Struyf, S. CD26/dipeptidylpeptidase IV-chemokine interactions: Double-edged regulation of inflammation and tumor biology. J. Leukoc. Biol. 2016, 99, 955-969. [CrossRef] [PubMed]

275. Monneau, Y.; Luo, L.; Sankaranarayanan, N.V.; Nagarajan, B.; Vivès, R.R.; Baleux, F.; Desai, U.R.; Arenzana-Seidedos, F.; LortatJacob, H. Solution structure of CXCL13 and heparan sulfate binding show that GAG binding site and cellular signalling rely on distinct domains. Open Biol. 2017, 7, 275. [CrossRef] 
276. Lau, E.K.; Paavola, C.D.; Johnson, Z.; Gaudry, J.P.; Geretti, E.; Borlat, F.; Kungl, A.J.; Proudfoot, A.E.; Handel, T.M. Identification of the glycosaminoglycan binding site of the CC chemokine, MCP-1: Implications for structure and function in vivo. J. Biol. Chem. 2004, 279, 22294-22305. [CrossRef]

277. Graham, G.J.; Wilkinson, P.C.; Nibbs, R.J.; Lowe, S.; Kolset, S.O.; Parker, A.; Freshney, M.G.; Tsang, M.L.; Pragnell, I.B. Uncoupling of stem cell inhibition from monocyte chemoattraction in MIP-1alpha by mutagenesis of the proteoglycan binding site. EMBO J. 1996, 15, 6506-6515. [CrossRef]

278. Proudfoot, A.E.I.; Fritchley, S.; Borlat, F.; Shaw, J.P.; Vilbois, F.; Zwahlen, C.; Trkola, A.; Marchant, D.; Clapham, P.R.; Wells, T. The BBXB Motif of RANTES Is the Principal Site for Heparin Binding and Controls Receptor Selectivity. J. Biol. Chem. 2001, 276, 10620-10626. [CrossRef]

279. Sepuru, K.M.; Nagarajan, B.; Desai, U.R.; Rajarathnam, K. Molecular Basis of Chemokine CXCL5-Glycosaminoglycan Interactions. J. Biol. Chem. 2016, 291, 20539-20550. [CrossRef]

280. Sepuru, K.M.; Rajarathnam, K. CXCL1/MGSA Is a Novel Glycosaminoglycan (GAG)-binding Chemokine: Structural Evidence for Two Distinct Non-Overlapping Binding Domains. J. Biol. Chem. 2016, 291, 4247-4255. [CrossRef]

281. Campanella, G.S.V.; Lee, E.M.J.; Sun, J.; Luster, A.D. CXCR3 and Heparin Binding Sites of the Chemokine IP-10 (CXCL10). J. Biol. Chem. 2003, 278, 17066-17074. [CrossRef] [PubMed]

282. Murphy, J.W.; Cho, Y.; Sachpatzidis, A.; Fan, C.; Hodsdon, M.E.; Lolis, E. Structural and Functional Basis of CXCL12 (Stromal Cell-derived Factor-1 $\alpha$ ) Binding to Heparin. J. Biol. Chem. 2007, 282, 10018-10027. [CrossRef] [PubMed]

283. Loos, T.; Mortier, A.; Gouwy, M.; Ronsse, I.; Put, W.; Lenaerts, J.-P.; Van Damme, J.; Proost, P. Citrullination of CXCL10 and CXCL11 by peptidylarginine deiminase: A naturally occurring posttranslational modification of chemokines and new dimension of immunoregulation. Blood 2008, 112, 2648-2656. [CrossRef]

284. Tuinstra, R.L.; Peterson, F.C.; Kutlesa, S.; Elgin, E.S.; Kron, M.A.; Volkman, B.F. Interconversion between two unrelated protein folds in the lymphotactin native state. Proc. Natl. Acad. Sci. USA 2008, 105, 5057-5062. [CrossRef] [PubMed]

285. Cox, J.H.; Dean, R.A.; Roberts, C.R.; Overall, C.M. Matrix Metalloproteinase Processing of CXCL11/I-TAC Results in Loss of Chemoattractant Activity and Altered Glycosaminoglycan Binding. J. Biol. Chem. 2008, 283, 19389-19399. [CrossRef]

286. De La Luz Sierra, M.; Yang, F.; Narazaki, M.; Salvucci, O.; Davis, D.; Yarchoan, R.; Zhang, H.H.; Fales, H.; Tosato, G. Differential processing of stromal-derived factor-1alpha and stromal-derived factor-1beta explains functional diversity. Blood 2004, 103, 2452-2459. [CrossRef]

287. Graham, G.J.; Handel, T.M.; Proudfoot, A.E. Leukocyte Adhesion: Reconceptualizing Chemokine Presentation by Glycosaminoglycans. Trends Immunol. 2019, 40, 472-481. [CrossRef]

288. Jouan, V.; Canron, X.; Alemany, M.; Caen, J.P.; Quentin, G.; Plouet, J.; Bikfalvi, A. Inhibition of In Vitro Angiogenesis by Platelet Factor-4-Derived Peptides and Mechanism of Action. Blood 1999, 94, 984-993. [CrossRef]

289. Vandercappellen, J.; Liekens, S.; Bronckaers, A.; Noppen, S.; Ronsse, I.; Dillen, C.; Belleri, M.; Mitola, S.; Proost, P.; Presta, M.; et al. The COOH-Terminal Peptide of Platelet Factor-4 Variant (CXCL4L1/PF-4var47-70) Strongly Inhibits Angiogenesis and Suppresses B16 Melanoma Growth In vivo. Mol. Cancer Res. 2010, 8, 322-334. [CrossRef]

290. Van Raemdonck, K.; Berghmans, N.; Vanheule, V.; Bugatti, A.; Proost, P.; Opdenakker, G.; Presta, M.; Van Damme, J.; Struyf, S. Angiostatic, tumor inflammatory and anti-tumor effects of CXCL4(47-70) and CXCL4L1(47-70) in an EGF-dependent breast cancer model. Oncotarget 2014, 5, 10916-10933. [CrossRef]

291. Bello, L.; Giussani, C.; Carrabba, G.; Pluderi, M.; Lucini, V.; Pannacci, M.; Caronzolo, D.; Tomei, G.; Villani, R.; Scaglione, F.; et al. Suppression of malignant glioma recurrence in a newly developed animal model by endogenous inhibitors. Clin. Cancer Res. 2002, 8, 3539-3548.

292. Ruytinx, P.; Janssens, R.; Berghmans, N.; Gouwy, M.; Ronsse, I.; Liekens, S.; Proost, P.; Van Damme, J.; Struyf, S. Relative distribution and biological characterization of CXCL4L1 isoforms in platelets from healthy donors. Biochem. Pharmacol. 2017, 145, 123-131. [CrossRef]

293. Kwong, J.; Kulbe, H.; Wong, D.; Chakravarty, P.; Balkwill, F. An antagonist of the chemokine receptor CXCR4 induces mitotic catastrophe in ovarian cancer cells. Mol. Cancer Ther. 2009, 8, 1893-1905. [CrossRef] [PubMed]

294. Huang, E.H.; Singh, B.; Cristofanilli, M.; Gelovani, J.; Wei, C.; Vincent, L.; Cook, K.R.; Lucci, A. A CXCR4 Antagonist CTCE-9908 Inhibits Primary Tumor Growth and Metastasis of Breast Cancer. J. Surg. Res. 2009, 155, 231-236. [CrossRef] [PubMed]

295. Hassan, S.; Buchanan, M.; Jahan, K.; Aguilar-Mahecha, A.; Gaboury, L.; Muller, W.J.; Alsawafi, Y.; Mourskaia, A.A.; Siegel, P.M.; Salvucci, O.; et al. CXCR4 peptide antagonist inhibits primary breast tumor growth, metastasis and enhances the efficacy of anti-VEGF treatment or docetaxel in a transgenic mouse model. Int. J. Cancer 2010, 129, 225-232. [CrossRef] [PubMed]

296. Wong, D.; Kandagatla, P.; Korz, W.; Chinni, S.R. Targeting CXCR4 with CTCE-9908 inhibits prostate tumor metastasis. BMC Urol. 2014, 14, 12. [CrossRef] [PubMed]

297. Porvasnik, S.; Sakamoto, N.; Kusmartsev, S.; Eruslanov, E.; Kim, W.-J.; Cao, W.; Urbanek, C.; Wong, D.; Goodison, S.; Rosser, C.J. Effects of CXCR4 antagonist CTCE-9908 on prostate tumor growth. Prostate 2009, 69, 1460-1469. [CrossRef] [PubMed]

298. Wong, D.; Korz, W. Translating an Antagonist of Chemokine Receptor CXCR4: From Bench to Bedside. Clin. Cancer Res. 2008, 14, 7975-7980. [CrossRef]

299. Egorova, A.; Kiselev, A.; Häkli, M.; Ruponen, M.; Baranov, V.; Urtti, A. Chemokine-derived peptides as carriers for gene delivery to CXCR4 expressing cells. J. Gene Med. 2009, 11, 772-781. [CrossRef] 
300. Egorova, A.; Shubina, A.; Sokolov, D.; Selkov, S.; Baranov, V.; Kiselev, A. CXCR4-targeted modular peptide carriers for efficient anti-VEGF siRNA delivery. Int. J. Pharm. 2016, 515, 431-440. [CrossRef]

301. Proudfoot, A.E.I.; Buser, R.; Borlat, F.; Alouani, S.; Soler, D.; Offord, R.E.; Schröder, J.-M.; Power, C.A.; Wells, T. Aminoterminally Modified RANTES Analogues Demonstrate Differential Effects on RANTES Receptors. J. Biol. Chem. 1999, 274, 32478-32485. [CrossRef]

302. Proudfoot, A.E.; Power, C.A.; Hoogewerf, A.J.; Montjovent, M.-O.; Borlat, F.; Offord, R.E.; Wells, T. Extension of Recombinant Human RANTES by the Retention of the Initiating Methionine Produces a Potent Antagonist. J. Biol. Chem. 1996, 271, 2599-2603. [CrossRef]

303. Canavese, M.; Altruda, F.; Silengo, L. Therapeutic Efficacy and Immunological Response of CCL5 Antagonists in Models of Contact Skin Reaction. PLoS ONE 2010, 5, e8725. [CrossRef] [PubMed]

304. Brandner, B.; Rek, A.; Diedrichs-Möhring, M.; Wildner, G.; Kungl, A.J. Engineering the glycosaminoglycan-binding affinity, kinetics and oligomerization behavior of RANTES: A tool for generating chemokine-based glycosaminoglycan antagonists. Protein Eng. Des. Sel. 2009, 22, 367-373. [CrossRef] [PubMed]

305. Robinson, S.C.; Scott, K.A.; Wilson, J.L.; Thompson, R.G.; Proudfoot, A.E.I.; Balkwill, F.R. A chemokine receptor antagonist inhibits experimental breast tumor growth. Cancer Res. 2003, 63, 8360-8365.

306. Swamydas, M.; Ricci, K.; Rego, S.L.; Dréau, D. Mesenchymal stem cell-derived CCL-9 and CCL-5 promote mammary tumor cell invasion and the activation of matrix metalloproteinases. Cell Adhes. Migr. 2013, 7, 315-324. [CrossRef]

307. Karagiannis, E.D.; Popel, A.S. Novel anti-angiogenic peptides derived from ELR-containing CXC chemokines. J. Cell Biochem. 2008, 104, 1356-1363. [CrossRef]

308. Koskimaki, J.E.; Karagiannis, E.; Rosca, E.V.; Vesuna, F.; Winnard, P.T.; Raman, V.; Bhujwalla, Z.M.; Popel, A.S. Peptides Derived from Type IV Collagen, CXC Chemokines, and Thrombospondin-1 Domain-Containing Proteins Inhibit Neovascularization and Suppress Tumor Growth in MDA-MB-231 Breast Cancer Xenografts. Neoplasia 2009, 11, 1285-IN2. [CrossRef]

309. Rosca, E.V.; Lal, B.; Koskimaki, J.E.; Popel, A.; Laterra, J. Collagen IV and CXC chemokine-derived antiangiogenic peptides suppress glioma xenograft growth. Anti Cancer Drugs 2012, 23, 706-712. [CrossRef]

310. Wang, P.; Yang, X.; Xu, W.; Li, K.; Chu, Y.; Xiong, S. Integrating individual functional moieties of CXCL10 and CXCL11 into a novel chimeric chemokine leads to synergistic antitumor effects: A strategy for chemokine-based multi-target-directed cancer therapy. Cancer Immunol. Immunother. 2010, 59, 1715-1726. [CrossRef] [PubMed]

311. Kaneider, N.C.; Agarwal, A.; Leger, A.J.; Kuliopulos, A. Reversing systemic inflammatory response syndrome with chemokine receptor pepducins. Nat. Med. 2005, 11, 661-665. [CrossRef]

312. Agarwal, A.; Tressel, S.L.; Kaimal, R.; Balla, M.; Lam, F.H.; Covic, L.; Kuliopulos, A. Identification of a Metalloprotease-Chemokine Signaling System in the Ovarian Cancer Microenvironment: Implications for Antiangiogenic Therapy. Cancer Res. 2010, 70, 5880-5890. [CrossRef]

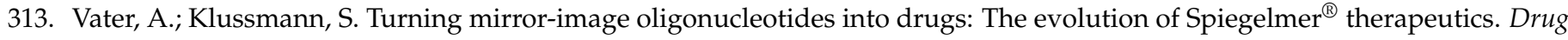
Discov. Today 2015, 20, 147-155. [CrossRef]

314. Hoellenriegel, J.; Zboralski, D.; Maasch, C.; Rosin, N.Y.; Wierda, W.G.; Keating, M.J.; Kruschinski, A.; Burger, J.A. The Spiegelmer NOX-A12, a novel CXCL12 inhibitor, interferes with chronic lymphocytic leukemia cell motility and causes chemosensitization. Blood 2014, 123, 1032-1039. [CrossRef] [PubMed]

315. Roccaro, A.; Sacco, A.; Purschke, W.G.; Moschetta, M.; Buchner, K.; Maasch, C.; Zboralski, D.; Zöllner, S.; Vonhoff, S.; Mishima, Y.; et al. SDF-1 Inhibition Targets the Bone Marrow Niche for Cancer Therapy. Cell Rep. 2014, 9, 118-128. [CrossRef]

316. Steurer, M.; Montillo, M.; Scarfo', L.; Mauro, F.R.; Andel, J.; Wildner, S.; Trentin, L.; Janssens, A.; Burgstaller, S.; Frömming, A.; et al. Olaptesed pegol (NOX-A12) with bendamustine and rituximab: A phase IIa study in patients with relapsed/refractory chronic lymphocytic leukemia. Haematologica 2019, 104, 2053-2060. [CrossRef] [PubMed]

317. Deng, L.; Stafford, J.H.; Liu, S.-C.; Chernikova, S.; Merchant, M.; Recht, L.; Brown, J.M. SDF-1 Blockade Enhances Anti-VEGF Therapy of Glioblastoma and Can Be Monitored by MRI. Neoplasia 2017, 19, 1-7. [CrossRef] [PubMed]

318. Zboralski, D.; Hoehlig, K.; Eulberg, D.; Frömming, A.; Vater, A. Increasing Tumor-Infiltrating T Cells through Inhibition of CXCL12 with NOX-A12 Synergizes with PD-1 Blockade. Cancer Immunol. Res. 2017, 5, 950-956. [CrossRef] [PubMed] 